UDK 781.97 Ramovš P.

\author{
Zoran Krstulović
}

Narodna in univerzitetna knjižnica, Ljubljana

National and University Library, Ljubljana

\title{
Seznam del skladatelja Primoža Ramovša
}

Seznam del akademika Primoža Ramovša ${ }^{1}$ zajema podatke o njegovih skladbah ter njihovih tiskanih objavah. Opira se na ohranjene rokopise in/ali čistopise, skladateljev popis del, že objavljene sezname njegovih skladb, ter kataloge večjih knjižnic. Večino skladateljevih rokopisov in čistopisov hrani Glasbena zbirka Narodne in univerzitetne knjižnice, če gre za druga nahajališča, so ta posebej navedena.

Pregled skladb je urejen po abecedi naslovov. Podatki se vrstijo po vzorcu: naslov, zasedba, kraj in datum nastanka, opis fizične oblike gradiva (rokopisa in čistopisa), na koncu je opomba o naslovu ter navedba posvetila. Popisu rokopisa (čistopisa) sledijo podatki o natisu(-ih). Naslov, ki se začne s števnikom je razrešen, tisti v drugi pisavi pa transliteriran. Pri objavah je naslov izpuščen, če je enak tistemu na rokopisu, pri večjezičnih naslovnicah so izpuščeni tudi vzporedni naslovi. Sledijo navedbe kraja izdaje, založbe, letnice izida, podatki o fizični obliki publikacije, ev. naslov zbirke ter založniška številka. Bibliografija zajema objavljeno gradivo, ki je izšlo do konca oktobra 1999.

Popisu so dodani Kronološki seznam del, Kazalo zasedb ter Kazalo oblik in $z v r s t i$. Kronološki seznam je urejen po datumih, ki jih je skladatelj, skoraj dosledno, zapisal na koncu skladbe. Rokopisi brez letnice so časovno razvrščeni na osnovi drugih virov. V kazalu zasedb so najprej razvrščena inštrumentalna, sledijo vokalna oz. vokalnoinštrumentalna dela. Znotraj inštrumentalne skupine se zasedbe vrstijo od solističnih in komornih do različnih orkestralnih. Kazalo oblik in zvrsti je urejeno po abecednem redu. 


\title{
MUZIKOLOŠKI ZBORNIK • MUSICOLOGICAL ANNUAL XXXV
}

\author{
Kratice: \\ čtp. $=$ čistopis \\ gl. = glej \\ op. $=$ opus \\ $\mathrm{rkp} .=$ rokopis \\ s.a. = sine anno, brez letnice izdaje \\ s.l. = sine loco, brez kraja izdaje \\ s.n. = sine nomine, brez imena založbe \\ str. $=$ stran, strani \\ zv. = zvezek, zvezki
}

A-CIs-fonia. Klavir. Rateče, 10.10.1981. Rkp., svinčnik, 4 str., 43 cm; čtp., flomaster, 12 str., 36 cm. Naslov na čistopisu: A - CIs - fonia za klavir. Posvetilo: Aciju!

A. D. 1986. Orgle. Rateče, 24.10.1986. Rkp., svinčnik, 5 str., 43 cm; čtp., flomaster, 15 str., 35 cm. Naslov na čistopisu: A. D. 1986 za orgle.

Natis: $\quad$ A. D. 1986 za orgle. Ljubljana, Društvo slovenskih skladateljev; Udine, Pizzicato edizioni musicali, 1990. 14 str., 24 x 32 cm. (Edicije Društva slovenskih skladateljev, 1249). P. $224 \mathrm{E}$.

À quattro. Kvartet violončelov. Ljubljana, 3.3.1978. Partitura, rkp., svinčnik, 5 str., $43 \mathrm{~cm}$.

ABSSA. Kljunasta flavta. Ljubljana, 27.4.1990. Rkp., svinčnik, 3 str., $43 \mathrm{~cm}$; čtp., flomaster, 7 str., $36 \mathrm{~cm}$. Naslov na čistopisu: ABSSA per flauto à becco.

Acuta za orgle. Ljubljana, 3.12.1971. Rkp., svinčnik, 8 str., 34 cm; čtp., flomaster, 21 str., 36 cm. Čistopis je popisan po kseroksni kopiji.

Natis: $\quad$ Acuta für Orgel. Köln, Musikverlag Hans Gerig, 1973. 15 str., 23 x 31 cm. HG 978.

[Adagio, non troppo]. Klavir. [Ljubljana, november 1945]. Rkp., svinčnik, str. [4], $31 \mathrm{~cm}$. Priključeno k: Loquebar za ženski zbor.

Adagio za violončelo in godalni orkester. Ljubljana, 5.11 .1958 . Particella, rkp., svinčnik, 3 str., 31 cm; partitura, čtp., črnilo, 13 str., $31 \mathrm{~cm}$.

Aforizmi za violo in klavir. Ljubljana, 29.3.1961. Partitura, rkp., svinčnik, 4 str., $31 \mathrm{~cm}+$ zapis tonske serije, [1] str., $21 \times 23 \mathrm{~cm}$.

Natis: Ljubljana, Društvo slovenskih skladateljev, 1964. Partitura, 7 str., $33 \mathrm{~cm}+1$ part, [3] str., $32 \mathrm{~cm}$. (Edicije Društva slovenskih skladateljev, 158).

Afriški ples, flavta, ksilofon, paličice, boben

gl. Mladinske skladbe za Orffov instrumentarij

Akatombo. Godalni kvartet. Rateče, 18.4.1997. Partitura, rkp., svinčnik, 2 str., 43 cm; čtp., flomaster, 6 str., $43 \mathrm{~cm}$. Naslov na čistopisu: Akatombo za godalni kvartet.

Akrostih za klavir. Ljubljana, 12.12.1969. Rkp., svinčnik, 3 str., 31 cm; čtp. (matrica), flomaster, 4 str., 34 $\mathrm{cm}$.

Natis: Ljubljana, [samozaložba], 1969. 4 str., $33 \mathrm{~cm}$. Reprodukcija skladateljevega rokopisa.

$A m-B e$. Klavir štiriročno. Ljubljana, 9.11.1994. Partitura, rkp., svinčnik, 2 str., 43 cm; čtp., flomaster, 6 str., $33 \mathrm{~cm}$. Naslov na čistopisu: Am - Be za klavir štiriročno. Posvetilo: Ambrožu in Benjaminu!

Ancia doppia. Angleški rog. Ljubljana, 7.4.1994. Rkp., svinčnik, 2 str., 43 cm; čtp., flomaster, 6 str., 36 cm. Naslov na čistopisu: Ancia doppia za angleški rog. Posvetilo: Melini!

Andante per viola (violino) e piccola orchestra

gl. Andante za violo in klavir

Andante za violo in klavir. Ljubljana, 23.10.1940. Partitura, čtp., črnilo, 6 str., $34 \mathrm{~cm}+1$ part za violo, črnilo, [1] str., $34 \mathrm{~cm}$.

Priredba: Andante za violo in mali orkester. [Ljubljana, 1941]. Pogrešano. Popisano po: B. Loparnik, Biti skladatelj, pogovori s Primožem Ramovšem; Ljubljana, Slovenska matica, 1984; str. 256. 


\section{MUZIKOLOŠKI ZBORNIK • MUSICOLOGICAL ANNUAL XXXV}

Ohranjen je part za violino, črnilo, [1] str., $33 \mathrm{~cm}$. Naslov na partu violine: Andante per viola (violino) e piccola orchestra.

\section{Andante za violo in mali orkester gl. Andante za violo in klavir}

Antiparalele za klavir in orkester. Ljubljana, 31.7.1966. Partitura, rkp., svinčnik, 50 str., 31 cm; čtp., črnilo, 105 str., $43 \mathrm{~cm}$. Čistopis se nahaja v Društvu slovenskih skladateljev.

Apantesis. Trio (trobenta, rog, klavir). Ljubljana, 27.9.1986. Partitura, rkp., svinčnik, 6 str., 43 cm; čtp., flomaster, 28 str., $35 \mathrm{~cm}$. Naslov na čistopisu: Apantesis za trobento, rog in klavir.

Apel za rog in komorni ansambel. Ljubljana, 23.11.1963. Partitura, rkp., svinčnik, 15 str., 31 cm; čtp., črnilo, 46 str., $31 \mathrm{~cm}$. Čistopis se nahaja v Društvu slovenskih skladateljev.

Natis: $\quad$ Apel za rog in komorni orkester. Ljubljana, Društvo slovenskih skladateljev, 1968. Partitura, 44 str., $29 \mathrm{~cm}$. (Edicije Društva slovenskih skladateljev, 324).

Áphixis (Andreíou). Trombon, tuba. Ljubljana, 18.1.1963. Partitura, rkp., svinčnik, 2 str., 31 cm. Naslov je izpisan $\mathrm{z}$ grškim alfabetom.

Arcofonia. Violina, klavir. Ljubljana, 27.11.1991. Partitura, rkp., svinčnik, 5 str., 43 cm; čtp., flomaster, 15 str., $35 \mathrm{~cm}$. Naslov na čistopisu: Arcofonia za violino in klavir. Posvetilo: Dragotu Arku!

Arioso

gl. Sedem skladb za godalni orkester

AS. Pihala, trobila, tolkala. Ljubljana, 7.3.1994; part tube (ad lib.) dodan 31.1.1995. Partitura, rkp., svinčnik, 17 str., $43 \mathrm{~cm}$; čtp., flomaster, 52 str., $35 \mathrm{~cm}$. Naslov na čistopisu: AS za pihala, trobila in tolkala. Posvetilo na čistopisu: Aleksandar Spasić. Čistopis je popisan po kseroksni kopiji.

ASAE. Orgle. Ljubljana, 14.1.1994. Rkp., svinčnik, 4 str., 43 cm; čtp., flomaster, 14 str., 35 cm. Naslov na čistopisu: Academia Scientiarum et Artium Europaea für Orgel. Čistopis je popisan po kseroksni kopiji. Posvetilo na rokopisu: Academiae Scientiarum et Artium Europae! Posvetilo na listku (tipkopis, 8 x 11 $\mathrm{cm}$ ) priloženem kseroksni kopiji čistopisa: Gelegentlich meiner Auswahl zum Mitglied der Europäischen Akademie der Wissenschaften und Künste habe ich diese Komposition geschaft und es ist mir eine besondere Ehre sie dieser Akademie zu widmen. Salzburg, am 12. März 1994. P.R.

Aulofonia. Oboa ali angleški rog, klavir. Ljubljana, 31.7.1975. Partitura, rkp., svinčnik, 9 str., 43 cm; čtp., črnilo, 27 str., $36 \mathrm{~cm}$. Naslov na čistopisu: Aulofonia za oboo (angleški rog) in klavir. Čistopis se nahaja v Društvu slovenskih skladateljev.

Avizo. Orgle. Ljubljana, 7.3.1989. Rkp., svinčnik, 1 str., 43 cm; čtp., flomaster, 4 str., 35 cm. Naslov na čistopisu: Avizo za orgle.

AVS. Trio (trobenta, rog, trombon). Ljubljana, 4.3.1992. Partitura, rkp., svinčnik, 6 str., 43 cm; čtp., flomaster, $13 \mathrm{str}$., $36 \mathrm{~cm}$. Naslov na čistopisu: AVS za trobilni trio.

Bagatela. Trio (flavta, dve violi). Ljubljana, 17.10.1945. Partitura, rkp., svinčnik, 2 str., $31 \mathrm{~cm}+1$ part za flavto, črnilo, 3 str., $30 \mathrm{~cm}+$ parta za violi, črnilo, à 3 str., $34 \mathrm{~cm}$. Naslov na partih: Bagatela za flavto in 2 violi.

Bagatele za klavir. [Ljubljana, 1956]. Rkp., svinčnik, str. 7-10, 31 cm; čtp., črnilo, 9 str., 35 cm. Vsebina: Uspavanka, Koral, Nokturno, Scherzo, Koračnica. Rokopis je priključen k: Tema z variacijami.

Natis: $\quad$ Slovenska glasbena revija 4/1956-1957, 2-3, 24-31.

Bagatele za violo. Ljubljana, 8.7.1954. Rkp., svinčnik, 3 str., $31 \mathrm{~cm}$; čistopisa, črnilo, à 7 str., 30 oz. $31 \mathrm{~cm}$. Naslov na drugem čistopisu: Bagattelle per viola solo. Posvetilo: Pavlu Merkùju!

Bagattelle per viola solo

gl. Bagatele za violo

Balada za violino, rog in klavir, op. 29. Otonu Župančiču za 60-letnico. Ljubljana, 5.6.1938. Partitura, rkp., črnilo, 5 str., $34 \mathrm{~cm}$; čtp., črnilo, 9 str., $31 \mathrm{~cm}+3$ parti, črnilo, à 1 str., $31 \mathrm{~cm}$.

Beati immaculati za deški zbor. Besedilo: Psalm 118,1. Ljubljana, 22.11.1945. Partitura, rkp., svinčnik, str. 2-3, $31 \mathrm{~cm}$. Priključeno k: Loquebar za ženski zbor. 


\section{MUZIKOLOŠKI ZBORNIK • MUSICOLOGICAL ANNUAL XXXV}

Beati immaculati, ženski zbor gl. 2 [Due] moteti in honorem S. Caeciliae

Beati immaculati. Ženski zbor, orgle. Ljubljana, 12.11.1946. Partitura, rkp., svinčnik, 2 str., 31 cm; čtp., črnilo, 4 str., $35 \mathrm{~cm}+1$ part za sopran in mezzosopran, 2 str., $31 \mathrm{~cm}+1$ part za alt, $1 \mathrm{str}$, $31 \mathrm{~cm}$. Podnaslov na čistopisu: Motetto.

Bravničar: Kralj Matjaž. Priredba začetnega Larga. 3 trobente, 4 rogovi, 3 tromboni, tuba. Ljubljana, 30.11.1977. Partitura, rkp., svinčnik, 2 str., 43 cm; čtp., črnilo, 4 str., $34 \mathrm{~cm}+11$ partov, črnilo, à 1 str., 34 $\mathrm{cm}$ (tr. I - cor. III), $36 \mathrm{~cm}$ (cor. IV - tb.).

Breve za klarinet in klavir. Ljubljana, 14.4.1967. Partitura, rkp., svinčnik, 5 str., $31 \mathrm{~cm}$.

Brez meja. Kvartet flavt, angleški rog. Ljubljana, 28.5.1994. Partitura, rkp., svinčnik, 6 str., 43 cm; čtp., flomaster, 14 str., $43 \mathrm{~cm}$. Naslov na čistopisu: Brez meja za kvartet flavt in angleški rog.

Brez strahu. Klarinet. Ljubljana, 17.8.1993. Rkp., svinčnik, 2 str., 43 cm; čtp., flomaster, 5 str., 36 cm. Naslov na čistopisu: Brez strahu za klarinet. Posvetilo: Borisu Renerju!

Budilka

gl. Tri skladbice za Polonco za klavir

Burleska za fagot in klavir. Ljubljana, 1.4.1960. Partitura, rkp., svinčnik, 3 str., 31 cm; čtp. (matrica), flomaster, 6 str., $36 \mathrm{~cm}$.

Natis: Ljubljana, [samozaložba], 1960. Partitura, 6 str., $34 \mathrm{~cm}$. Reprodukcija skladateljevega rokopisa.

Caesar vincit. Fagot. Ljubljana, 4.5.1995. Rkp., svinčnik, 2 str., $43 \mathrm{~cm}$; čtp., flomaster, 5 str., $35 \mathrm{~cm}$. Naslov na čistopisu: Caesar vincit za fagot. Posvetilo: Vojku Cesarju!

Cala la notte, glas, klavir

gl. Nočprihaja, op. 22

Cantabo Domino. Glas, orgle. Ljubljana, 17.11.1952. Partitura, rkp., svinčnik, 1 str., 8 x 24 cm.

Canto ferno in Do-minore

gl. Koral za citre v c-molu, op. $10 a$

Carillon

gl. Mala suita za klavir

Carillon. Klavir štiriročno. [Ljubljana], 14.10.1953. Rkp., svinčnik, str. 2-4, $31 \mathrm{~cm}$. Priključeno k: Tema $z$ variacijami.

Celeia laboribus suis gaudens. Godalni orkester. Ljubljana, 13.3.1993. Partitura, rkp., svinčnik, 10 str., 43 cm; čtp., črnilo, 20 str., $42 \mathrm{~cm}$. Naslov na čistopisu: Celeia laboribus suis gaudens za godalni orkester. Čistopis se nahaja v Društvu slovenskih skladateljev.

Chordophonia. Klavirski kvartet. Ljubljana, 16.5.1981. Partitura, rkp., svinčnik, 11 str., 43 cm; čtp., flomaster, 31 str., $36 \mathrm{~cm}$. Naslov na čistopisu: Chordophonia za klavirski kvartet. Posvetilo: Ljubljanskemu klavirskemu kvartetu!

Ciklus za klavir. Ljubljana, 19.4.1966. Rkp., svinčnik, 6 str., 31 cm; čtp. (matrica), flomaster, $10 \mathrm{str} ., 34 \mathrm{~cm}$. Natis: Ljubljana, [samozaložba], $1966.10 \mathrm{str} ., 33 \mathrm{~cm}$.

Cinque o quattro. Kvartet oz. kvintet flavt. Ljubljana, 22.5.1993. Partitura, rkp., svinčnik, 6 str., 43 cm; čtp., flomaster, $15 \mathrm{str} ., 33 \mathrm{~cm}$. Naslov na čistopisu: Cinque o quattro per flauti. Posvetilo na čistopisu: Alle brave al[1]ieve della Maestra Luisa Sello!

Circulations za harfo. Ljubljana, 16.10.1965. Rkp., svinčnik, 7 str., $31 \mathrm{~cm}$.

Natis: $\quad$ Cirkulacije za harfo. Ljubljana, Društvo slovenskih skladateljev; Köln, Musikverlage Hans Gerig, 1973. 13 str., 35 cm. (Edicije Društva slovenskih skladateljev, 548). HG 1046.

Clar-perc. Klarinet, tolkala. Ljubljana, 16.8.1988. Partitura, rkp., svinčnik, 4 str., 43 cm; čtp., flomaster, 8 str., $35 \mathrm{~cm}$. Naslov na čistopisu: Clar - perc za klarinet in tolkala.

Colloquium. Harfa, godalni kvartet. Ljubljana, 18.12.1970. Partitura, rkp., svinčnik, 17 str., 43 cm; čtp., flomaster, 40 str., $36 \mathrm{~cm}$. Naslov na čistopisu: Colloquium za harfo in godalni kvartet. Posvetilo: Pavli Uršičevi in Zagrebškemu godalnemu kvartetu! 


\section{MUZIKOLOŠKI ZBORNIK • MUSICOLOGICAL ANNUAL XXXV}

Colloquium quinquae virorum. Klavirski kvintet. Ljubljana, 28.10.1998. Partitura, rkp., svinčnik, 12 str., $43 \mathrm{~cm}$; čtp., flomaster, 28 str., $28 \times 30 \mathrm{~cm}$. Naslov na čistopisu: Colloquium quinque virorum za klavirski kvintet.

Con sordino za trobento, pozavno in klavir. Ljubljana, 12.8.1969. Partitura, rkp., svinčnik, 10 str., 31 cm; čtp., flomaster, 29 str., $34 \mathrm{~cm}$. Čistopis je popisan po kseroksni kopiji v Nototeki RTV Slovenije.

Natis: Con sordino za trobento, trombon in klavir. Ljubljana, Društvo slovenskih skladateljev; Köln, Musikverlage Hans Gerig, 1974. Partitura, 13 str., 34 cm. (Edicije Društva slovenskih skladateljev, 545). HG 1106.

Concertino per pianoforte ed orchestra d'archi. Ljubljana, 28.10.1948. Particella, rkp., svinčnik, 16 str., 31 $\mathrm{cm}$; partitura, čtp., črnilo, 28 str., $43 \mathrm{~cm}$. Naslov na čistopisu: Concertino za klavir in godalni orkester. Priključeno na 16 str. rokopisa: [ Vse najboljše, dragi Eto].

Natis: Concertino za klavir in godalni orkester. Ljubljana, Prosvetni servis, 1960. Partitura, 27 str., 30 $\mathrm{cm}+18$ partov ([132] str.). (Instrumentalne skladbe, 6). Sprejeto v Edicije Društva slovenskih skladateljev, ed. št. 635.

Concertino za klavir in godalni orkester

gl. Concertino per pianoforte ed orchestra d'archi

Concertino za trobento in orkester. Ljubljana, 13.7.1960. Particella, rkp., svinčnik, 17 str., 31 cm; partitura, čtp., črnilo, 42 str., $43 \mathrm{~cm}$.

Concerto à becco. Kljunasta flavta, komorni orkester. Ljubljana, 4.2.1980. Partitura, rkp., svinčnik, 29 str., $43 \mathrm{~cm}$; čtp., črnilo, 74 str., $42 \mathrm{~cm}$. Naslov na čistopisu: Concerto à becco za kljunasto flavto in komorni orkester. Posvetilo: Klemenu! Čistopis se nahaja v Društvu slovenskih skladateljev.

Concerto da camera. Orgle, godalni orkester. Ljubljana, 26.7.1995. Partitura, rkp., svinčnik, 14 str., $43 \mathrm{~cm}$; čtp., črnilo, 25 str., $42 \mathrm{~cm}$. Naslov na čistopisu: Concerto da camera za orgle in godala. Čistopis se nahaja v Društvu slovenskih skladateljev.

Concerto doppio. Kljunasta flavta, prečna flavta, orkester. Rateče, 5.10.1983. Partitura, rkp., svinčnik, 29 str., $43 \mathrm{~cm}$; čtp., flomaster, 66 str., $42 \mathrm{~cm}$. Naslov na čistopisu: Concerto doppio za kljunasto in prečno flavto ter orkester. Čistopis se nahaja v Društvu slovenskih skladateljev.

Concerto piccolo per fagotto e orchestra d'archi

gl. Concerto piccolo za fagot in godalni orkester

Concerto piccolo za fagot in godalni orkester. Ljubljana, 13.12.1958. Particella, rkp., svinčnik, 12 str., 31 cm; partitura, čtp., črnilo, 39 str., $31 \mathrm{~cm}+1$ part, 9 str., $34 \mathrm{~cm}$. Naslov na čistopisu: Concerto piccolo per fa-gotto e orchestra d'archi. Posvetilo: Ivanu Turšiču! Part se nahaja v arhivu Slovenske filharmonije.

Natis: Concerto piccolo per fagotto e orchestra d'archi. Ljubljana, Društvo slovenskih skladateljev, 1961. Partitura, 28 str., $34 \mathrm{~cm}$. (Edicije Društva slovenskih skladateljev, 102).

Concerto profano. Orgle, orkester. Rateče, 16.10.1984. Partitura, rkp., svinčnik, 24 str., 43 cm; čtp., flomaster, 66 str., $42 \mathrm{~cm}$. Naslov na čistopisu: Concerto profano za orgle in orkester. Posvetilo: Mariji Řihánkovi! Čistopis se nahaja v Društvu slovenskih skladateljev.

Confinium. Orgle. Ljubljana, 30.4.1992. Rkp., svinčnik, 6 str., 43 cm; čtp., flomaster, 15 str., 36 cm. Naslov na čistopisu: Confinium za orgle. Posvetilo: Daliborju Miklavčiču!

Coniunctio za trombon in orgle. Rateče, 6.10.1976. Partitura, rkp., svinčnik, 7 str., 43 cm; čtp., flomaster, 18 str., $35 \mathrm{~cm}$. Čistopis je popisan po kseroksni kopiji. Posvetilo na čistopisu: Mojstru trombona Branimirju Slokarju!

Corale + Siciliana

gl. Suita za 2 violini, violončelo in godalni orkester

Credo. Orgelske improvizacije posvečene papežu Janezu Pavlu II. [Ljubljana, maj 1996]. Popisano po skladateljevem seznamu del, videoposnetku (Ljubljana, Založba kaset in plošč RTV, 1996) ter zvočnem posnetku (CD, Ljubljana, samozaložba, p 1997).

Crescendo. Klarinet, klavir. Ljubljana, 22.11.1980. Partitura, rkp., svinčnik, 1 str., 43 cm; čtp., flomaster; 4 str., $36 \mathrm{~cm}+1$ part, [1] str., $36 \mathrm{~cm}$. Naslov na čistopisu: Crescendo za klarinet in klavir.

Natis: Skladbe za klarinet in klavir. Slovenski skladatelji. Izbor in redakcija Slavko Goričar. Ljubljana, Državna založba Slovenije, 1984. Str. 18-20. 


\section{MUZIKOLOŠKI ZBORNIK • MUSICOLOGICAL ANNUAL XXXV}

Cum jubilo. Kvintet trobil (trobenta I, trobenta II, rog, trombon, tuba). Ljubljana, 3.2.1992. Partitura, rkp., svinčnik, 5 str., $43 \mathrm{~cm}$; čtp., flomaster, 19 str., 36 cm. Naslov na čistopisu: Cum jubilo za trobilni kvintet.

Cudodelna roka, op. 2. Opera v petih slikah. Besedilo Fran Milčinski. Ljubljana, 26.6.1933. Partitura, rkp., svinčnik, 1. zv., str. 1-32; 2. zv., str. 33-66; 3. zv., str. 69-101, 35 cm (1. zv.), 31 cm (2. in 3. zv.). Priključeno: Uvertura Bizetjeve opere «Carmen za violino, klavir, trobento in tolkala; Cudodelna roka, op. 10b, uvertura.

Cudodelna roka, op. 10b. Uvertura. Violina, klavir. [Ljubljana, 1935]. Partitura na posebnem listu, rkp., svinčnik, str. 1-2, cm. Priključeno k: Cudodelna roka, op. 2.

$D-S$. Klarinet, klavir. Ljubljana, 13.9.1994. Paritura, rkp., svinčnik, 4 str., 43 cm; čtp., flomaster, 13 str., 36 $\mathrm{cm}$. Naslov na čistopisu: D - S za klarinet in klavir.

$D D$ : 70. Klavir štiriročno. Ljubljana, 25.6.1990. Partitura, rkp., svinčnik, 70 str., 43 cm; čtp., flomaster, 26 str., 36 cm. Naslov na čistopisu: DD : 70 za klavir štiriročno. Posvetilo: À Duo Dekleva!

DDZ. Pihalni trio. Ljubljana, 8.3.1990. Partitura, rkp., svinčnik, 7 str., 43 cm; čtp., flomaster, 15 str., $35 \mathrm{~cm}$. Naslov na čistopisu: DDZ za pihalni trio.

Decem anni prospere peracti. Klavirski kvartet. Ljubljana, 29.5.1996. Partitura, rkp., svinčnik, 8 str., 43 cm; čtp., flomaster, 16 str., $35 \mathrm{~cm}$. Naslov na čistopisu: Decem anni prospere peracti za klavirski kvartet. Čistopis je popisan po kseroksni kopiji. Posvetilo: À Musikforum Viktring!

Deus Israël conjungat vos. Motet za bariton in orgle. Besedilo: Job 7,15 in 8,19; psalmi 127,3 in 19,3. Ljubljana, 27.4.1955. Partitura, rkp., svinčnik, 3 str., $31 \mathrm{~cm}$. Posvetilo: Pavlu Merkùju za poroko!

Dež, flavta, ksilofon, zvončki

gl. Mladinske skladbe za Orffov instrumentarij

Diagram za tolkala. S klavirjem. Ljubljana, 31.1.1976. Partitura, rkp., svinčnik, 6 str., $43 \mathrm{~cm}$.

Dialog für Klavier und Orchester

gl. Dialog za klavir in orkester

Dialog in simfonija. Flavta, čembalo. Ljubljana, 3.2.1966. Partitura, rkp., svinčnik, 12 str., $31 \mathrm{~cm}$.

Dialog za klavir in orkester. Ljubljana, 2.6.1980. Partitura, rkp., svinčnik, 47 str., 43 cm; čtp., flomaster, 76 str., $43 \mathrm{~cm}$. Naslov na čistopisu: Dialog für Klavier und Orchester.

Dialogi za dva klavirja. Ljubljana, 24.2.1962. Partitura, rkp., svinčnik, 17 str., $31 \mathrm{~cm}+$ zapis tonske serije, [1] str., 20 × 26 cm; čtp. (matrica), flomaster, 22 str., $35 \mathrm{~cm}$. Naslov na čistopisu: Dialogi za 2 klavirja.

Natis: Ljubljana, [samozaložba], 1962. Partitura, 22 str., $34 \mathrm{~cm}$. Reprodukcija skladateljevega rokopisa. Posvetilo: Za klavirski duo Gita Mally - Igor Dekleva.

Dies irae. Kantata. Mešani zbor, orkester. Besedilo po Otonu Župančiču, Dies irae (V zarje Vidove) in po Apokalipsi VI,10, VII,12,17. Ljubljana, 12.4.1939. Particella, rkp., svinčnik, 25 str., 16 x 24 cm (str. 1-10), 32 cm (str. 11-25); partitura, čtp., črnilo, 45 str., $35 \mathrm{~cm}$; partitura, čtp., črnilo, 33 str., $53 \mathrm{~cm}$. Naslov na čistopisu: Dies irae. Kantata za zbor in veliki orkester.

Dilema. Klarinet, klavir. Ljubljana, 28.2.1991. Partitura, rkp., svinčnik, 6 str., 43 cm; čtp., flomaster, 16 str., $35 \mathrm{~cm}$. Naslov na čistopisu: Dilema za klarinet in klavir.

Diminuendo. Klarinet, klavir. Ljubljana, 22.11.1980. Partitura, rkp., svinčnik, 1 str., 43 cm; čtp., flomaster, 4 str., $36 \mathrm{~cm}+1$ part, [1] str., $36 \mathrm{~cm}$. Naslov na čistopisu: Diminuendo za klarinet in klavir.

Natis: Skladbe za klarinet in klavir. Slovenski skladatelji. Izbor in redakcija Slavko Goričar. Ljubljana, Državna založba Slovenije, 1984. Str. 21-23.

Diptychon orationis. Mešani zbor. Ljubljana, 22.6.1951. Partitura, rkp., svinčnik, 4 str., $31 \mathrm{~cm}$.

Natis: $\quad$ Cerkveni glasbenik 78/1985, 10-12, notna priloga 25-32.

Discessus. Nonet trobil ( 3 trobente, 3 rogovi, 3 tromboni). Ljubljana, 20.2.1993. Partitura, rkp., svinčnik, 3 str., $43 \mathrm{~cm}$; čtp., flomaster, 5 str., $43 \mathrm{~cm}$. Naslov na čistopisu: Discessus za ansambel trobil.

Divertimento per 2 cornetti, timpani ed archi. Siena, 30.8.1941. Particella, rkp., svinčnik, 27 str., 16 x 24 cm (str. 1-6), 32 cm (str. 4-18), 34 cm (str. 19-26), 17 x 28 cm (str. 27); partitura, čtp., črnilo, 46 str., 34 cm. 


\section{MUZIKOLOŠKI ZBORNIK • MUSICOLOGICAL ANNUAL XXXV}

Naslov na čistopisu: Divertimento per 2 cornetti, timpani e orchestra d'archi. Naslov v skladateljevem seznamu del: Divertimento št. 1.

Divertimento št. 1

gl. Divertimento per 2 cornetti, timpani ed archi

Divertimento št. 2

gl. Divertimento za 2 oboi, fagot in godalni orkester

Divertimento št. 3 za godalni orkester. Ljubljana, 3.7.1944. Particella, rkp., svinčnik, 12 str., 31 cm; partitura, čtp., črnilo, 29 str., $43 \mathrm{~cm}$. Naslov na čistopisu: Divertimento za godalni orkester. Čistopis se nahaja v arhivu Slovenske filharmonije.

Divertimento za 2 oboi, fagot in godalni orkester. Roma, 21.1.1943. Particella, rkp., svinčnik, 16 str., 33 cm (str. 1-12), 34 cm (str. 13-16). Naslov v skladateljevem seznamu del: Divertimento št. 2.

Divertimento za godalni orkester

gl. Divertimento št. 3 za godalni orkester

Dobro

gl. Ocene za klavir

Dovolj naj bo

gl. Dovolj za zdaj

Dovolj za zdaj. Violončelo, klavir. Ljubljana, 8.4.1995. Partitura, rkp., svinčnik, 3 str., 43 cm; čtp., flomaster, 11 str., $36 \mathrm{~cm}$. Naslov na čistopisu: Dovolj za zdaj za violinčelo in klavir. Naslov v skladateljevem seznamu del: Dovolj naj bo.

Doživetje. Orgle, tolkala. Ljubljana, 27.4.1989. Partitura, rkp., svinčnik, 8 str., 43 cm; čtp., flomaster, 33 str., $35 \mathrm{~cm}$. Naslov na čistopisu: Doživetje za orgle in tolkala.

2. [Druga] simfonija

gl. Simfonija II.

II. [Druga] suita za klavir. Ljubljana, 16.11.1954. Rkp., svinčnik, 10 str., 31 cm. Posvetilo: Prof. Marici Vogelnikovi!

II. [Drugi] godalni kvartet. Rim, 27.1.1942. Partitura, rkp., svinčnik, 7 str., 27 cm (str. 1-2), 34 cm (str. 3-6), $14 \times 28 \mathrm{~cm}$ (str. 7).

Dual. Trobenta, orgle. Rateče, 15.6.1983. Partitura, rkp., svinčnik, 7 str., 43 cm; čtp., flomaster, 19 str., 36 $\mathrm{cm}$. Naslov na čistopisu: Dual za trobento in orgle.

2 [Due] moteti in honorem S. Caeciliae. Ženski zbor. Besedilo: Psalmi 188,46-47, 118,1. Ljubljana, 21.22.11.1945. Partitura, čtp., črnilo, 9 str., $34 \mathrm{~cm}$. Vsebina: Loquebar, Beati immaculati.

Natis: $\quad$ Cerkveni glasbenik 78/1985, 4-6, notna priloga 9-16. Vsebina: Beati immaculati (Psalm 118, 1), 9-12, Loquebar (Psalm 188, 46-47), 13-16.

Duo. Flavta, oboa. Ljubljana, 19.7.1991. Partitura, rkp., svinčnik, 5 str., 43 cm; čtp., flomaster, 11 str., 36 $\mathrm{cm}$. Naslov na čistopisu: Duo za flavto in oboo. Posvetilo: Milošu in Ireni!

Duo concertante za flavto, harfo, godala in tolkala. Rateče, 22.6.1979. Partitura, rkp., svinčnik, 35 str., 43 cm; čtp., črnilo, 73 str., $42 \mathrm{~cm}$. Čistopis se nahaja v Društvu slovenskih skladateljev.

Duo za oboo in orkester. Rateče, 17.11.1973. Partitura, rkp., svinčnik, 27 str., 43 cm; čtp., flomaster, 96 str., $42 \mathrm{~cm}$. Posvetilo: Dragu Golobu! Čistopis se nahaja v Društvu slovenskih skladateljev.

Duplex. Trombon, klavir. Ljubljana, 23.1.1991. Partitura, rkp., svinčnik, 6 str., 43 cm; čtp., flomaster, 16 str., $35 \mathrm{~cm}$. Naslov na čistopisu: Duplex za trombon in klavir. Posvetilo: Kirilu Ribarskemu!

$2 \times 2$ [Dva krat dva] za klavir štiriročno. Ljubljana, 9.9.1980. Partitura, rkp., svinčnik, 5 str., 43 cm; čtp., flomaster, 20 str., $36 \mathrm{~cm}$. Posvetilo: Alešu!

Dva nokturna za kitaro. Ljubljana, 22.7.1967. Rkp., svinčnik, 4 str., $31 \mathrm{~cm}$.

Natis: $\quad$ Zwei Nocturnes für Gitarre. Köln, Musikverlag Hans Gerig, 1968. 7 str., 30 cm. HG 635 . 


\section{MUZIKOLOŠKI ZBORNIK • MUSICOLOGICAL ANNUAL XXXV}

Dve koralni predigri za orgle. Ljubljana, 7.12.1963. Rkp., svinčnik, 7 str., $31 \mathrm{~cm}+$ zapis tonske serije, [1] str., 16 × $23 \mathrm{~cm}$; čtp. (matrica), 15 str., $33 \mathrm{~cm}$.

Natisa: Ljubljana, [samozaložba], 1963.15 str., $33 \mathrm{~cm}$. Reprodukcija skladateljevega rokopisa. Ljubljana, Društvo slovenskih skladateljev, 1994. 10 str., 35 cm. (Edicije Društva slovenskih skladateljev, 1369).

Dve šaljivki

gl. $1+1$ [Ena plus ena je ena] za klavir

Dve uspavanki za flavto in klavir. Ljubljana, 25.4.1958. Partitura, rkp., svinčnik, 4 str., 31 cm. Posvetilo: Jasni Merkùjevi!

Natis: $\quad$ Ljubljana, [samozaložba], 1962. Partitura, 8 str., $30 \mathrm{~cm}+1$ part, 2 str., $30 \mathrm{~cm}$. Posvetilo: Jasni Merkù.

Dvojčki. Dva violončela. Ljubljana, 21.11.1991. Partitura, rkp., svinčnik, 3 str., 43 cm; čtp., flomaster, 8 str., $36 \mathrm{~cm}$. Naslov na čistopisu: Dvojčki za dva violončela. Posvetilo: Ediju Majaronu!

Dvoje oči. Harfa, klavir. Ljubljana, 23.1.1988. Partitura, rkp., svinčnik, 6 str., 43 cm; čtp., flomaster, 24 str., $36 \mathrm{~cm}$. Naslov na čistopisu: Dvoje oči za harfo in klavir.

Dvojica za klavir. Ljubljana, 16.2.1971. Rkp., svinčnik, 6 str., 43 cm (str. 1-4), 36 cm (str. 5-6).

Eikón. Orgle. Rateče, 1.10.1985. Rkp., svinčnik, 5 str., 43 cm; čtp., flomaster, 14 str., 35 cm. Naslov na čistopisu: Eikón za orgle. Rokopis je popisan po kseroksni kopiji.

Eirene. Viola da gamba. Ljubljana, 13.3.1987. Rkp., svinčnik, 1 str., $43 \mathrm{~cm}$; čtp., flomaster, 4 str., $35 \mathrm{~cm}$. Naslov na čistopisu: Eirene za violo da gamba. Posvetilo: Ireni Pahor!

Ekspanzija za altousko flavto. Ljubljana, 10.8.1963. Rkp., svinčnik, 3 str., $31 \mathrm{~cm}$.

Natis: $\quad$ Ekspanzija za flavto. Ljubljana, Društvo slovenskih skladateljev, 1965. [2] str., $32 \mathrm{~cm}$. (Edicije Društva slovenskih skladateljev, 278). Reprodukcija skladateljevega rokopisa.

Ekstremi za solo violino. Ljubljana, 21.8.1970. Rkp., svinčnik, $5 \mathrm{str} ., 31 \mathrm{~cm}$; čtp., flomaster, 7 str., $36 \mathrm{~cm}$.

Elegija za violino in kontrabas. Ljubljana, 26.11.1974. Partitura, rkp., svinčnik, 2 str., $43 \mathrm{~cm}$.

Elementi. Kvintet trobil (mala trobenta, trobenta, rog, trombon, tuba). Ljubljana, 28.6.1977. Partitura, rkp., svinčnik, 12 str., 43 cm; čtp., črnilo, 20 str., 36 cm. Naslov na čistopisu: Elementi za kvintet trobil. Posvetilo: Komponirano po naročilu Društva slovenskih skladateljev za kvintet trobil Slovenske filharmonije. Čistopis se nahaja v Društvu slovenskih skladateljev.

$1+1=1$ [Ena plus ena je ena] za klavir. Ljubljana, 29.12.1969. Rkp., svinčnik, 2 str., 31 cm; čtp. (matrica), flomaster, 4 str., $34 \mathrm{~cm}$. Posvetilo: Za Polonco!

Natis: Ljubljana, [samozaložba], 1969. 4 str., $33 \mathrm{~cm}$. Reprodukcija skladateljevega rokopisa. Na izvodu, ki ga hrani Društvo slovenskih skladateljev je skladatelj s kemičnim svinčnikom dopisal podnaslov Dve šaljviki.

Enica. Klavir. Ljubljana, 30.9.1974. Rkp., svinčnik, [1] str., 43 cm.

Enneafonia. Komorni ansambel. Ljubljana, 25.1.1963. Partitura, rkp., svinčnik, 14 str., 31 cm; čtp., črnilo, 47 str., $36 \mathrm{~cm}$. Posvetilo na čistopisu: Ansamblu "Slavko Osterc" in njegovemu vodji Ivu Petriću!

Natis: Ljubljana, Društvo slovenskih skladateljev, 1967. Partitura, 44 str., 30 cm. (Edicije Društva slovenskih skladateljev, 250).

Epizoda. Tolkala (1 izvajalec). Rateče, 20.9.1974. Partitura, rkp., svinčnik, 3 str., 43 cm; čtp., flomaster, 7 str., $36 \mathrm{~cm}$. Naslov na čistopisu: Epizoda za tolkala.

Ernönek za harmoniko. Rateče, 19.6.1986. Rkp., svinčnik, [3] str., 43 cm; čtp., flomaster, 9 str., 36 cm.

Etuda za flavto solo. Rateče, 19.11.1973. Rkp., svinčnik, [1] str., 43 cm.

Ewig treu. Minnelied unbekannter Herkunft. Glas, klavir. Ljubljana, 15.9.1953. Partitura, rkp., svinčnik, 1 str., $31 \mathrm{~cm}$. Posvetilo: Moji Štefici!

Ex uno. Dva klavirja, tolkala (2 izvajalca). Ljubljana, 16.3.1973. Partitura, rkp., svinčnik, 15 str., 43 cm; čtp., flomaster, $41 \mathrm{str}$., $36 \mathrm{~cm}$. Naslov na čistopisu: Ex uno za 2 klavirja in 2 tolkalca. 


\section{MUZIKOLOŠKI ZBORNIK • MUSICOLOGICAL ANNUAL XXXV}

Extension. Basovski klarinet. Ljubljana, 19.8.1992. Rkp., svinčnik, 3 str., 43 cm; čtp., flomaster, 7 str., 36 $\mathrm{cm}$. Naslov na čistopisu: Extension za basovski klarinet. Posvetilo: À Ratko Vojtek.

\section{Fanfara}

gl. Sedem skladb za godalni orkester

Fanfara, trio flavt, činele, boben

gl. Mladinske skladbe za Orffov instrumentarij

Fanfara za orgle. Ljubljana, 30.4.1955. Rkp., svinčnik, 3 str., 31 cm; čtp., flomaster, 5 str., 36 cm. Posvetilo: Gospe Marti Merkùjevi za poroko!

Fantasia per pianoforte. Ljubljana, 12.9.1940. Čtp., črnilo, 8 str., 34 cm; čtp., črnilo, ? str., $34 \mathrm{~cm}$, nepopolno. Naslov na nepopolnem čistopisu: Fantazija za klavir. Posvetilo na nepopolnem čistopisu: Svojemu dobremu očetu za petdesetletnico.

Fantazija za čembalo. Rateče, 27.10.1977. Rkp., svinčnik, 4 str., 43 cm; čtp., flomaster, 10 str., 36 cm. Posvetilo: Hubertu Bergantu!

Fantazija za klavir. [Ljubljana, 1938]. Pogrešano. Popisano po: B. Loparnik, Biti skladatelj, pogovori s Primožem Ramovšem; Ljubljana, Slovenska matica, 1984; str. 255. Skladateljev seznam del skladbe ne navaja.

Fantazija za klavir(1940)

gl. Fantasia per pianoforte

Figura v miniaturah za violončelo in klavir. Ljubljana, 6.4.1967. Partitura, rkp., svinčnik, 6 str., $31 \mathrm{~cm}$.

Finale, flavta, zvončki, ksilofon, trikotnik, činele, paličice, boben, pavke gl. Mladinske skladbe za Orffov instrumentarij

Finale za orkester. Ljubljana, 25.8.1966. Particella, rkp., svinčnik, 18 str., 31 cm. Posvetilo: Prof. Vinku Šušteršiču!

Fluktuacije za komorni ansambel. Ljubljana, 14.8.1964. Partitura, rkp., svinčnik, 21 str., $31 \mathrm{~cm}+$ zapis tonske serije, [1] str., $16 \times 23 \mathrm{~cm}$ + navodila dirigentu in izvajalcem, 5 str., $30 \mathrm{~cm}$; čtp., črnilo, $58 \mathrm{str}$., $36 \mathrm{~cm}$. $\mathrm{Na}$ hrbtni strani naslovnice rokopisa: Za Muzički biennale Zagreb 1965. Čistopis se nahaja v Društvu slovenskih skladateljev.

Fonosaxia. Kvartet saksofonov. Ljubljana, 4.5.1996. Partitura, rkp., svinčnik, 5 str., 43 cm; čtp., flomaster, 16 str., $34 \mathrm{~cm}$. Naslov na čistopisu: Fonosaxia za kvartet saksofonov. Čistopis je popisan po kseroksni kopiji. Posvetilo: Glasbeni šoli Velenje!

Natis: $\quad$ Fonosaxia za kvartet saksofonov. Ljubljana, Društvo slovenskih skladateljev, 1997. Partitura, 15 str., 34 cm. (Edicije Društva slovenskih skladateljev, 1428). Reprodukcija skladateljevega rokopisa.

Forte - piano. Viola, klavir. Ljubljana, 14.2.1987. Partitura, rkp., svinčnik, 2 str., 43 cm; čtp., flomaster, 5 str., $35 \mathrm{~cm}$. Naslov na čistopisu: Forte - piano za violo in klavir.

Forte-piano. (TAKA-SO). Klavir. Ljubljana, 28.10.1997. Rkp., svinčnik, 2 str., 43 cm; čtp., flomaster, 6 str., $36 \mathrm{~cm}$. Naslov na čistopisu: Forte - piano za klavir.

Fragmenti za fagot. Ljubljana, Rateče, 9.10.1976. Rkp., svinčnik, 3 str., 43 cm; čtp., flomaster, 7 str., $36 \mathrm{~cm}$. Fuga in Do-maggiore, op. 12, no. 3. Flavta, fagot. Ljubljana, 9.2.1936; komponirano, 15.1.1936. Partitura, čtp., črnilo, 1 str., $25 \times 26 \mathrm{~cm}$.

Fuga in Do-maggiore, op. 13, no. 1. Godalni trio. Ljubljana, 8.2.1936; komponirano, 22.1.1936. Partitura, čtp., črnilo, str. 3-4. Priključeno k: Fuga in Re-maggiore, op. 12, no. 2.

Fuga in Do-maggiore, op. 13, no. 2. [Ljubljana, 1936]. Pogrešano. Popisano po: B. Loparnik, Biti skladatelj, pogovori s Primožem Ramovšem; Ljubljana, Slovenska matica, 1984; str. 254.

Fuga in Re-maggiore, op. 12, no. 1. Violina, violončelo. Ljubljana, 22.12.1935. Partitura, čtp., črnilo, str. 23; prepis str. [5]. Priključeno k: Fuga in Re-maggiore, op. 12, no. 2.

Fuga in Re-maggiore, op. 12, no. 2. Godalni trio. Ljubljana, 22.12.1935. Partitura, čtp., črnilo, str. 1-2. Priključeno: Fuga in Re-maggiore, op. 12, no. 1, Fuga in Do-maggiore, op. 13, no. 1. 


\section{MUZIKOLOŠKI ZBORNIK • MUSICOLOGICAL ANNUAL XXXV}

Fuga in Sol-maggiore con preludio, op. 13, no. 3. [Ljubljana, 1936]. Pogrešano. Popisano po: B. Loparnik, Biti skladatelj, pogovori s Primožem Ramovšem; Ljubljana, Slovenska matica, 1984; str. 254.

Fuga, [op. 26]. Orkester. Bled - Mlino, 9.8.1938. Particella, rkp., svinčnik, 12 str., 31 cm; partitura, čtp., črnilo, 44 str., $34 \mathrm{~cm}$. Naslov na čistopisu: Fuga za veliki orkester.

Fuga za veliki orkester

gl. Fuga, [op. 26]

Fyrir Rannveig - con amore. Oboa d'amore, viola d'amore. Ljubljana, 14.8.1996. Partitura, rkp., svinčnik, 3 str., $43 \mathrm{~cm}$; čtp., flomaster, 10 str., $34 \mathrm{~cm}$. Čistopis je popisan po kseroksni kopiji.

Gavotta, klavir štiriročno

gl. Suita za 2 violini, violončelo in godalni orkester

Gavotte

gl. Suita za 2 violini, violončelo in godalni orkester

Gibanja za klavir. Ljubljana, 19.12.1967. Rkp., svinčnik, 5 str., 31 cm; čtp. (matrica), flomaster, 8 str., 34 cm.

Natis: $\quad$ Ljubljana, [samozaložba], $1967.8 \mathrm{str}$., $33 \mathrm{~cm}$. Reprodukcija skladateljevega rokopisa.

Gigue

gl. Suita za 2 violini, violončelo in godalni orkester

Godalni kvartet. Ljubljana, 12.1.1939. Partitura, rkp., svinčnik, 16 str., 35 cm (str. 1-8), 31 cm (str. 9-16).

Godalni trio, op. 17 [a]. Ljubljana, 7.6.1937. Partitura, rkp., svinčnik (začetek črnilo), 8 str., 34 cm (str. 16), $31 \mathrm{~cm}$ (str. 7-8); čtp., črnilo, 9 str., $34 \mathrm{~cm}$.

Gratulatio. Klavir. Ljubljana, 27.7.1993. Rkp., svinčnik, 3 str., 43 cm; čtp., flomaster, 7 str., 34 cm. Naslov na čistopisu: Gratulatio za klavir. Čistopis je popisan po kseroksni kopiji. Posvetilo na rokopisu: Adriani Magdorski! Posvetilo na čistopisu: Adriani Magdorski s posebnimi čestitkami ob ameriški nagradi!

Gre zares. Dva klavirja. Ljubljana, 14.3.1995. Partitura, rkp., svinčnik, 3 str., 43 cm; čtp., flomaster, 9 str., $33 \mathrm{~cm}$. Naslov na čistopisu: Gre zares za 2 klavirja.

Gregorjev binkoštni preludij. Violina, klavir. Ljubljana, 28.5.1955. Partitura, rkp., svinčnik, [1] str., $31 \mathrm{~cm}$. Posvetilo: Gregorju Tozonu!

Gugalni stol za violino in klavir. Ljubljana, 4.1.1940. Partitura, čtp., črnilo, 5 str., $34 \mathrm{~cm}+1$ part, [1] str., 34 $\mathrm{cm}$.

Güttler: Ko sem pod oljkami. Kvintet (flavta, violina I, violina II, viola, violončelo). Ljubljana, instrumentiral 24.2.1982. Partitura, rkp., svinčnik, [1] str., $43 \mathrm{~cm}$.

Hagios Athanatos. Orgle. Ljubljana, 31.1.1989. Rkp., svinčnik, 5 str., 43 cm; čtp., flomaster, 13 str., 35 cm. Naslov na čistopisu: Hagios Athanatos za orgle.

$H E-A L$. Flavta, klavir. Ljubljana, 18.11.1981. Partitura, rkp., svinčnik, 5 str., 43 cm; čtp., flomaster, 14 str., $36 \mathrm{~cm}$. Naslov na čistopisu: HE - AL za flavto in klavir. Posvetilo: Heleni in Ảlešu!

Himna brigade. [Zemljo draga, obalo naša...]. Dvoglasni zbor. Besedilo Dušan Dožudić. Pogrešano. Popisano po: B. Loparnik, Biti skladatelj, pogovori s Primožem Ramovšem; Ljubljana, Slovenska matica, 1984; str. 257, skladateljevem seznamu del in natisu.

Natis: Glas naših jedinica. [Šibenik, samozaložba], 1947. Str. [3]. Naslov na ovoju: Kroz borbu i takmičenje, 1944-1947.

Improvizacije za harfo. Ljubljana, 10.4.1973. Rkp., svinčnik, 4 str., 43 cm; čtp., flomaster, 13 str., $36 \mathrm{~cm}$. Posvetilo: Pavli Uršičevi!

Natis: Ljubljana, Društvo slovenskih skladateljev, 1983. 12 str., $34 \mathrm{~cm}$. (Edicije Društva slovenskih skladateljev, 1038). Posvetilo: À Pavla Uršič.

Impulzi za oboo in harfo. Ljubljana, 30.10.1967. Partitura, rkp., svinčnik, 6 str., 31 cm; čtp. (matrica), flomaster, [11] str., $34 \mathrm{~cm}$. Čistopis je popisan po ohranjeni naslovni strani.

Natisa: Ljubljana, [samozaložba], 1967. Partitura, 11 str., $34 \mathrm{~cm}$. Reprodukcija skladateljevega rokopisa. 


\section{MUZIKOLOŠKI ZBORNIK • MUSICOLOGICAL ANNUAL XXXV}

Impulzi für Oboe und Harfe. Köln, Musikverlag Hans Gerig, 1969. Partitura, 12 str., 31 cm. HG 707.

In modo tedesco. Marimbafon. Ljubljana, 14.3.1996. Rkp., svinčnik, 2 str., 43 cm; čtp., flomaster, 7 str., 35 $\mathrm{cm}$. Naslov na čistopisu: In modo tedesco per marimba. Posvetilo: Al Maestro Fabian Perez Tedesco!

In piam memoriam. Oboa, viola, harfa. Ljubljana, 22.5.1992. Partitura, rkp., svinčnik, 10 str., $43 \mathrm{~cm}+$ list z motivi, kemični svinčnik, [1] str., $43 \mathrm{~cm}$; čtp., flomaster, $18 \mathrm{str}$., $42 \mathrm{~cm}$. Naslov na čistopisu: In piam memoriam za oboo, violo in harfo. Posvetilo: Ob 100-letnici Marija Kogoja!

Inavguracija. Harmonika, orgle. Ljubljana, 15.7.1992. Partitura, rkp., svinčnik, 11 str., 43 cm; čtp., flomaster, 17 str., $43 \mathrm{~cm}$. Naslov na čistopisu: Inavguracija za harmoniko in orgle. Čistopis je popisan po kseroksni kopiji.

Intermezzo

gl. Sedem skladb za godalni orkester

Intermezzo za violino in harfo. Ljubljana, 22.5.1959. Partitura, rkp., svinčnik, 3 str., $31 \mathrm{~cm}$.

Intrada. Orkester. Ljubljana, 11.8.1962. Particella, rkp., svinčnik, 20 str., 31 cm; partitura, čtp., črnilo, 44 str., $32 \mathrm{~cm}$. Naslov na čistopisu: Intrada za orkester. Čistopis se nahaja v arhivu Slovenske filharmonije.

Natis: Intrada za orkester. [Ljubljana, samozaložba], 1962.30 partov ([120] str.), $30 \mathrm{~cm}$.

Introitus solemnis. Kvintet trobil (trobenta, 2 rogova, 2 trombona), orgle. Ljubljana, 15.7.1977. Partitura, rkp., svinčnik, 4 str., $43 \mathrm{~cm}$; čtp., flomaster, 9 str., $36 \mathrm{~cm}$.

Inventiones pastorales. Orgle. Ljubljana, 13.1.1967. Rkp., svinčnik, 8 str., 31 cm; čtp. (matrica), flomaster, $15 \mathrm{~cm}$.

Natisa: Inventiones pastorales za orgle. Ljubljana, [samozaložba], 1967. 15 str., 33 cm. Reprodukcija skladateljevega rokopisa.

Inventiones pastorales für Orgel. Köln, Musikverlag Hans Gerig, 1970. 20 str., 24 x 31 cm. HG 773.

Inverzija za čelo in klavir. Ljubljana, 31.8.1971. Partitura, rkp., svinčnik, 8 str., 35 cm; čtp., flomaster, 16 str., $36 \mathrm{~cm}$; čtp., črnilo, 16 str., $36 \mathrm{~cm}$. Naslov na čistopisu: Inverzija za violončelo in klavir. Drugi čistopis se nahaja v Društvu slovenskih skladateljev.

Iz "Cicibana" za mladinski zbor. Besedilo Oton Župančič. Ljubljana, 11.-12.1.1956. Partitura, rkp., svinčnik, [3] str., $31 \mathrm{~cm}$. Vsebina: 1. Uspavanka, 2. Mehurčki, 3. Kroparji.

Iz Miniatur za klavir, violina, klavir

gl. Miniature za klavir

Izpolnjena želja. Dve harmoniki. Ljubljana, 6.9.1997. Partitura, rkp., svinčnik, 4 str., 43 cm; čtp., flomaster, 11 str., $33 \mathrm{~cm}$. Naslov na čistopisu: Izpolnjena želja za dve harmoniki.

Izpoved. Orkester. Rateče, 12.6.1986. Partitura, rkp., svinčnik, 24 str., 43 cm; čtp., črnilo, 61 str., 42 cm. Naslov na čistopisu: Izpoved za simfonični orkester. Čistopis se nahaja v Društvu slovenskih skladateljev.

Jubilejna uvertura. Orkester. Ljubljana, 17.1.1975. Partitura, rkp., svinčnik, 10 str., 43 cm. Posvetilo: Prof. Vinku Šušteršiču!

Jubilejni crescendo. Orkester. Rateče, 19.11.1997. Partitura, rkp., svinčnik, 32 str., 43 cm. Posvetilo: Srednji glasbeni in baletni šoli v Ljubljani!

Kadenca $k$ Tartinijevemu violinskemu koncertu v D-duru. Violina. [Ljubljana, 1957]. Rkp., svinčnik, [1] str., $31 \mathrm{~cm}$.

Kadenca za solo violončelo. Ljubljana, 20.12.1977. Rkp., svinčnik, 1 str., 43 cm; čtp., flomaster, 8 str., 36 $\mathrm{cm}$. Čistopis je popisan po kseroksni kopiji. Posvetilo: Cirilu Škerjancu!

Kako je pridna Micka prišla v nebesa, op. 1. Opera v treh dejanjih. Besedilo Primož Ramovš. [Ljubljana], 30.11.1932. Partitura, rkp., svinčnik, 1. zv. (12 str.), 2. zv. (16 str.), 3. zv. (12 str.), 16 x 24 cm (1. in 2. zv.), $35 \mathrm{~cm}$ (3. zv.).

Kanizij, Kanizij. Ženski zbor. [Ljubljana], 1956. Partitura, rkp., svinčnik, str. [2], $31 \mathrm{~cm}$. Priključeno k: Zvonovi zvonijo. 


\section{MUZIKOLOŠKI ZBORNIK • MUSICOLOGICAL ANNUAL XXXV}

Kanon

gl. Sedem skladb za godalni orkester

Kanon, zvončki, ksilofon

gl. Mladinske skladbe za Orffov instrumentarij

Kanoni za 2 ali 3 glasove. Mladinski zbor. Onomatopoetična besedila. Ljubljana, 8.1.1968. Partitura, rkp., svinčnik, 2 str., $31 \mathrm{~cm}$. Vsebina: Trobenta (onomatopoetično besedilo), Kurja družina (onomatopoetično besedilo), Ples (besedilo Primož Ramovš), Mestni promet (besedilo Primož Ramovš).

Delna natisa: Trobenta; Kurja družina. - v: Grlica 12/1968, 3, notni del 29-30.

Ples; Mestni promet. - v: Grlica 12/1968, 4-5, dodatek 5-6.

Kantilena. Violina, orgle. Ljubljana, 8.4.1982. Partitura, rkp., svinčnik, 6 str., 43 cm; čtp., flomaster, 16 str., $36 \mathrm{~cm}$. Naslov na čistopisu: Kantilena za violino in orgle. Posvetilo: Tomažu Lorenzu!

Natis: Kantilena za violino in orgle. Ljubljana, Društvo slovenskih skladateljev, 1986. Partitura, 16 str., $34 \mathrm{~cm}$. (Edicije Društva slovenskih skladateljev, 1125).

Keratofonia. Rog. Ljubljana, 16.2.1989. Rkp., svinčnik, 3 str., 43 cm; čtp., flomaster, 7 str., 36 cm. Naslov na čistopisu: Keratofonia für Horn. Čistopis je popisan po kseroksni kopiji.

$K I-R I-$ fonia. Trombon, pihalni kvintet. Ljubljana, 26.1.1990. Partitura, rkp., svinčnik, 9 str., 43 cm; čtp., flomaster, 26 str., $35 \mathrm{~cm}$. Naslov na čistopisu: KI - RI - fonia za trombon in pihalni kvintet.

$K I-R I-$ fonia variata. Trombon, kvintet trobil (trobenta I, trobenta II, rog, trombon, tuba). Ljubljana, 5.2.1991. Partitura, rkp., svinčnik, 9 str., $43 \mathrm{~cm}$; čtp., flomaster, 25 str., $36 \mathrm{~cm}$. Naslov na čistopisu: KI - RI fonia variata za trombon in trobilni kvintet.

Kitajska pesem, flavta, zvončki, metalofon gl. Mladinske skladbe za Orffov instrumentarij

Klar-kvar. Kvartet klarinetov. Ljubljana, 6.9.1995. Partitura, rkp., svinčnik, 4 str., 43 cm; čtp., flomaster, $13 \mathrm{str}$., $35 \mathrm{~cm}$. Naslov na čistopisu: Klar - kvar za kvartet klarinetov.

Klavir naj začne. Trio (klarinet, violončelo, klavir). Ljubljana, 25.11.1992. Partitura, rkp., svinčnik, 7 str., $43 \mathrm{~cm}$; čtp., flomaster, 13 str., $42 \mathrm{~cm}$. Naslov na čistopisu: Klavir naj začne za klarinet, violončelo in klavir.

Klavir za dva. Klavir štiriročno. Ljubljana, 13.8.1975. Partitura, rkp., svinčnik, 3 str., 43 cm. Posvetilo: Alenki in Igorju Dekleva!

Kolo. Klavirski trio (violina, violončelo, klavir). Ljubljana, 12.11.1941. Partitura, rkp., svinčnik, 6 str., 34 $\mathrm{cm}$.

Natis: Kolo za violino, violončelo in klavir. [Ljubljana], AccordiA, [s. a.]. Partitura, 11 str., $30 \mathrm{~cm}+2$ parta à 2 str., $30 \mathrm{~cm}$.

Kolovrat za orkester violin in klavir. Ljubljana, 19.11.1986. Partitura, rkp., svinčnik, 3 str., 43 cm; čtp., flomaster, 7 str., $42 \mathrm{~cm}$.

Kotysanka dla maleńkiego Marcina. Klavir. Ljubljana, 15.7.1997. Rkp., svinčnik, [1] str., 43 cm; čtp., flomaster, 3 str., $35 \mathrm{~cm}$. Čistopis je popisan po kseroksni kopiji.

Kombinacija za flavto in klavir. Ljubljana, 5.6.1964. Partitura, rkp., svinčnik, 5 str., $31 \mathrm{~cm}$.

Koncert za dva klavirja in godalni orkester. Ljubljana, 30.12.1949. Particella, rkp., svinčnik, 42 str., 31 cm; partitura, čtp., črnilo, 78 str., $43 \mathrm{~cm}$. Posvetilo na particelli: In memoriam Alfredo Casella.

Koncert za 2 klavirja in orkester. Ljubljana, 5.8.1981. Partitura, rkp., svinčnik, 56 str., 43 cm; čtp., črnilo, 88 str., 42 cm. Posvetilo: À Duo Dekleva! Čistopis se nahaja v Društvu slovenskih skladateljev.

Koncert za fagot in orkester. Rateče, 14.10.1978. Partitura, rkp., svinčnik, 63 str., 43 cm; čtp., črnilo, 90 str., $43 \mathrm{~cm}$.

Koncert za klavir in orkester. Ljubljana, 9.9.1946. Particella, rkp., svinčnik, 34 str., $31 \mathrm{~cm}+$ dodatki, [7] str. (a-h), [5] str. (A-E), $31 \mathrm{~cm}+$ listek z opombami, [1] str., 16 x $21 \mathrm{~cm}$; partitura, čtp., črnilo, 161 str., $32 \mathrm{~cm}$.

Koncert za klavir in veliki orkester, op. 14. Ljubljana, 1936. Partitura, čtp., črnilo, 112 str., 35 cm.

Koncert za kontrabas in orkester. Rateče, 28.5.1976. Partitura, rkp., svinčnik, 32 str., 43 cm; čtp., črnilo, 88 str., $43 \mathrm{~cm}$. Posvetilo: Ljupču Samardžiskemu! Čistopis se nahaja v Društvu slovenskih skladateljev. 


\section{MUZIKOLOŠKI ZBORNIK • MUSICOLOGICAL ANNUAL XXXV}

Koncert za kontrabasovsko tubo. Tuba, klavir. [Ljubjana], 1987. Pogrešano. Popisano po skladateljevem seznamu del.

Koncert za orgle in orkester. Ljubljana, 6.5.1983. Partitura, rkp., svinčnik, 32 str., 43 cm; čtp., črnilo, 80 str., $42 \mathrm{~cm}$. Čistopis se nahaja v Društvu slovenskih skladateljev.

Koncert za trobento in orkester. Rateče, 19.6.1985. Partitura, rkp., svinčnik, 32 str., 43 cm; čtp., flomaster, 81 str., 42 cm. Posvetilo: Stanku Arnoldu. Čistopis se nahaja v Društvu slovenskih skladateljev.

Natis: $\quad$ Ljubljana, Društvo slovenskih skladateljev, 1987. Partitura, 81 str., $33 \mathrm{~cm}$. (Edicije Društva slovenskih skladateljev, 1144). Posvetilo: À Stanko Arnold. Reprodukcija skladateljevega rokopisa.

Koncert za tubo in orkester. Rateče, 23.10.1976. Partitura, rkp., svinčnik, 23 str., 43 cm; klavirski izvleček, čtp., flomaster, 16 str., $35 \mathrm{~cm}$. Naslov na klavirskem izvlečku: Koncert za kontrabasovsko tubo.

Koncert za violino in violo. Z orkestrom. Ljubljana, 14.7.1961. Particella, rkp., svinčnik, 37 str., 31 cm; partitura, čtp., črnilo, 85 str., $42 \mathrm{~cm}$. Naslov na čistopisu: Koncert za violino, violo in orkester. Part za violončelo je prirejen iz solističnega parta viole. Ljubljana, 29.2.1988. Rkp., svinčnik, 3 str., 43 cm. Naslov na partu violončela: Koncert za violino, violončelo in orkester.

Natisa: Koncert za violino, violo in orkester. Ljubljana, Društvo slovenskih skladateljev, 1964. Partitura, $60 \mathrm{str}$., $33 \mathrm{~cm}$. (Edicije Društva slovenskih skladateljev, 187).

Koncert za violino, violo in orkester. [2. izd.]. Ljubljana, Društvo slovenskih skladateljev; Köln, Musikverlage Hans Gerig, 1978. Partitura, 60 str., $21 \mathrm{~cm}$. (Edicije Društva slovenskih skladateljev, 187). HG 1336. Prevzeto v založbo Breitkopf und Härtel, Wiesbaden.

Koncert za violino, violončelo in orkester

gl. Koncert za violino in violo

Koncert za violončelo in orkester. [Ljubljana, 1974]. Čtp., črnilo, 92 str., 42 cm. Posvetilo: Cirilu Škerjancu! Čistopis se nahaja v Društvu slovenskih sklädateljev.

Natis: $\quad$ Ljubljana, Društvo slovenskih skladateljev, 1982. Partitura, 92 str., $34 \mathrm{~cm}$. (Edicije Društva slovenskih skladateljev, 699). Posvetilo: Cirilu Škerjancu. Reprodukcija skladateljevega rokopisa.

Koncertantna glasba za pavke in orkester. Ljubljana, 16.11.1961. Particella, rkp., svinčnik, 19 str., $31 \mathrm{~cm}$. Natis: Klavirski izvleček. Rid. F. Perez Tedesco. [S. 1., s. n., s. a.]. Računalniški izpis, [16] str., $30 \mathrm{~cm}$.

Koncertantni diptih. Klavir, orkester. Ljubljana, 23.1.1996. Partitura, rkp., svinčnik, 64 str., 43 cm; čtp., črnilo, 84 str., $42 \mathrm{~cm}$. Posvetilo: Sonji Pahor-Torre! Naslov na čistopisu: Koncertantni diptih za klavir in orkester. Čistopis se nahaja v Društvu slovenskih skladateljev.

Kongresni avizo 98, flavta, klavir

gl. Kongresni avizo = Praeludium, flavta, harfa

Kongresni avizo = Praeludium. Flavta, harfa. Ljubljana, 21.3.1997. Partitura, rkp., svinčnik, 2 str., $43 \mathrm{~cm}$. Priredbi: Kongresni avizo za klarinet in harfo. Ljubljana, [1997]. Partitura, čtp., flomaster, 5 str., $35 \mathrm{~cm}$. Čistopis je popisan po kseroksni kopiji.

Kongresni avizo 98. Nova verzija za flavto in klavir. Ljubljana, 17.3.1998. Partitura, rkp., svinčnik, 2 str., $43 \mathrm{~cm}$; čtp., flomaster, 6 str., $36 \mathrm{~cm}$. Naslov na čistopisu: Kongresni avizo $98 \mathrm{za}$ flavto in klavir. Čistopis je popisan po kseroksni kopiji.

Kongresni avizo za klarinet in harfo

gl. Kongresni avizo = Praeludium, flavta, harfa

Konkretna študija št. 1 za magnetofonski trak. Ljubljana, 1961. Popisano po: B. Loparnik, Biti skladatelj, pogovori s Primožem Ramovšem; Ljubljana, Slovenska matica, 1984; str. 262 in skladateljevem seznamu del.

Konkretna študija št. 2 za magnetofonski trak. Ljubljana, 1961. Popisano po: B. Loparnik, Biti skladatelj, pogovori s Primožem Ramovšem; Ljubljana, Slovenska matica, 1984; str. 262 in skladateljevem seznamu del.

Konstanta in sekvence za klavir. Ljubljana, 23.4.1965. Rkp., svinčnik, 13 str., 31 cm. Posvetilo: J., zvesti poustvarjalki mojih del, v znak iskrene hvaležnosti ne samo za toliko krstnih izvedb, ampak predvsem za verno podajanje moje glasbe. 


\section{MUZIKOLOŠKI ZBORNIK • MUSICOLOGICAL ANNUAL XXXV}

Kontra B. Fagot, godalni kvintet. Ljubljana, 29.2.1996. Partitura, rkp., svinčnik, 6 str., 43 cm; čtp., flomaster, 19 str., $35 \mathrm{~cm}$. Naslov na čistopisu: Kontra B za fagot in godalni kvintet. Posvetilo: Zoranu Mitevu!

Kontra - koncert. Orgle, sekstet saksofonov, orkester. Ljubljana, 11.2.1997. Partititura, rkp., svinčnik, 45 str., $43 \mathrm{~cm}$; čtp., črnilo, 57 str., $42 \mathrm{~cm}$ (str. 1-52, 55-57), $53 \mathrm{~cm}$ (53-54) + nekaj napotkov za prosto improvizacijo, str. 58. Naslov na čistopisu: Kontra - koncert za orgle, 6 saxofonov in orkester. Čistopis se nahaja v Društvu slovenskih skladateljev.

Kontrafonia. Kvartet kontrabasov. Ljubljana, 19.4.1994. Partitura, rkp., svinčnik, 4 str., 43 cm; čtp., flomaster, 8 str., $43 \mathrm{~cm}$. Naslov na čistopisu: Kontrafonia za kvartet kontrabasov. Posvetilo: Zoranu Markoviću!

Kontrasti za klavirski trio. Ljubljana, 24.7.1961. Partitura, rkp., svinčnik, 7 str., $31 \mathrm{~cm}$. Posvetilo: Triu Lorenz!

Natisa: Kontrasti za violino, violončelo in klavir. Ljubljana, Društvo slovenskih skladateljev, 1966. Partitura, 12 str., 29 cm. + 2 parta, à 3 str., 29 cm. (Edicije Društva slovenskih skladateljev, 279). Posvetilo: Triu Lorenz.

Kontrasti za violino, violončelo in klavir. [2. izd.]. Ljubljana, Društvo slovenskih skladateljev, 1979. Partitura, 11 str., $34 \mathrm{~cm}+2$ parta à 2 str. (Edicije Društva slovenskih skladateljev, 279).

Koračnica

gl. Bagatele za klavir

Koračnica po napevih slovenskih narodnih pesmi, op. 9. Klavir. Ljubljana, 22.5.1935. Rkp., črnilo, str. 16$17,31 \mathrm{~cm}$. Priključeno k: Variacije na "An die Freude" iz IX. Beethovenove simphonije, op. 8.

Koračnica, trikotnik, činele, paličice, boben

gl. Mladinske skladbe za Orffov instrumentarij

Koračnica, violina, klavir

gl. Miniature za klavir

Korajža velja. Violončelo, klavir. Ljubljana, 1.4.1992. Partitura, rkp., svinčnik, 3 str., 43 cm; čtp., flomaster, 9 str., $36 \mathrm{~cm}$. Naslov na čistopisu: Korajža velja za violončelo in klavir.

Koral

gl. Bagatele za klavir

Koral

gl. Mala suita za klavir

Koral

gl. Sedem skladb za godalni orkester

Koral in tokata. Orkester. Ljubljana, 28.12.1955. Particella, rkp., svinčnik, 42 str., 31 cm; partitura, čtp., črnilo, 75 str., $42 \mathrm{~cm}$. Naslov na čistopisu: Koral in tokata za orkester. Čistopis se nahaja v Društvu slovenskih skladateljev.

Koral-Siciliana, klavir štiriročno

gl. Suita za 2 violini, violončelo in godalni orkester

Koral za citre v c-molu, op. 10a. [Ljubljana], 1935. Pogrešano. Popisano po: B. Loparnik, Biti skladatelj, pogovori s Primožem Ramovšem; Ljubljana, Slovenska matica, 1984; str. 254. Gl. tudi listek pri Orpheus in Euridika, op. 4: Koral v c-molu, à Dragica Repe, Canto ferno in Do-minore, op. 10a, 7 x 24 cm.

Kristalni gozd. Scenska glasba za komorni ansambel. Ljubljana, 29.11.1967. Partitura, rkp., svinčnik, 16 str., $31 \mathrm{~cm}$; čtp., flomaster, 19 str., $43 \mathrm{~cm}+12$ partov, à 4 str., $36 \mathrm{~cm}$. Za televizijsko dramo.

Križ- kraž. Klavir. Ljubljana, 27.8.1991. Rkp., svinčnik, [1] str., 43 cm; čtp., flomaster, 3 str., 36 cm.

Kroparji

gl. Iz "Cicibana" za mladinski zbor

Kurja družina, mladinski zbor

gl. Kanoni za 2 ali 3 glasove

Kvartet. Flavta, violina, violončelo, čembalo. Ljubljana, 20.9.1988. Partitura, rkp., svinčnik, 8 str., 43 cm; čtp., flomaster, 22 str., $35 \mathrm{~cm}$. Naslov na čistopisu: Kvartet za flavto, violino, violončelo in čembalo. 


\section{MUZIKOLOŠKI ZBORNIK • MUSICOLOGICAL ANNUAL XXXV}

Kvartet za rogove. Ljubljana, septembra 1939. Partitura brez naslova, rkp., črnilo, 5 str., $34 \mathrm{~cm}+5$ partov, à 2 str., $31 \mathrm{~cm}$; nedokončan čtp., črnilo brez naslova, 3 str., $34 \mathrm{~cm}$; čtp., črnilo, 14 str., $31 \mathrm{~cm}$. Posvetilo na čistopisu: Svojemu dragemu profesorju poklanja vdani Primož Ramovš. V Ljubljani, dne 20. maja 1940.

[Largo]. Godalni kvartet. [Ljubljana, okrog 1940]. Parti, rkp., črnilo, [1] str., 17 x 25 cm, (violončelo); čtp., črnilo, à [1] str., $31 \mathrm{~cm}$ (violina I, violončelo), $34 \mathrm{~cm}$ (violina II, viola).

Largo, klavir

gl. Tri skladbe

Lekcija za pihala, trobila in tolkala. Ljubljana, 31.1.1975. Partitura, rkp., svinčnik, 11 str., 43 cm; čtp., črnilo, 28 str., $42 \mathrm{~cm}$. Posvetilo: Igorju Karlinu! Čistopis se nahaja v Društvu slovenskih skladateljev.

$L J-O-T$. Orgle. Ljubljana, 3.9.1993. Rkp., svinčnik, 4 str., $43 \mathrm{~cm}$; čtp., flomaster, 11 str., $36 \mathrm{~cm}$. Naslov na čistopisu: LJerka - Očić - Turkulin. Posvetilo: Ljerki Očić Turkulin!

Loquebar za ženski zbor. Besedilo: Psalm 188,46-47. Ljubljana, 21.11.1945. Partitura, rkp., svinčnik, str. 12, $31 \mathrm{~cm}$. Priključeno: Beati immaculati za deški zbor; [Adagio, non troppo], klavir.

Loquebar, ženski zbor

gl. 2 [Due] moteti in honorem S. Caeciliae

Luwigana 1144. Trio (klarinet, violončelo, klavir). Ljubljana, 3.11.1994. Partitura, rkp., svinčnik, 7 str., 43 cm; čtp., flomaster, 13 str., $33 \mathrm{~cm}$. Naslov na čistopisu: Luwigana 1144 za klarinet, violončelo in klavir.

Mala suita za klavir. Ljubljana, 15.1.1946. Rkp., svinčnik, 4 str., 31 cm; čtp. (krtačni odtis), 13 str., 30 cm. Stavki: Preludij, Carillon, Pastorale, Scherzo, Koral.

Natis: Ljubljana, [samozaložba], 1958. 13 str., $30 \mathrm{~cm}$. Sprejeto v Edicije Društva slovenskih skladateljev, ed. št. 276.

Delna natisa: Allegretto (Pastorale); Vivace (Scherzo). - v: Slovenska glasbena revija 1/1951-52, 3-4, 5459.

Carillon; Pastorale. - v: Jugoslawisches Jugendalbum für Klavier 1. Herausgegeben Marijan Lipovšek. Leipzig, Edition Peters, 1975. Nr. 9633a. Str. 47-49.

Mala suita za klavir in godalni orkester. Ljubljana, 23.7.1957. Particella, rkp., svinčnik, 9 str., $31 \mathrm{~cm}$.

Mali Jožek. Otroški zbor. Besedilo Oton Župančič. [Ljubljana], 1944. Pogrešano. Popisano po skladateljevem seznamu del.

Mali nokturno za klavir. [Ljubljana, 1964]. Čtp. (matrica), flomaster, 3 str., $34 \mathrm{~cm}$.

Natis: [Ljubljana, samozaložba], 1964.3 str., $33 \mathrm{~cm}$. Čelni naslov.

Mali ples

gl. Tri skladbice za Polonco za klavir

Marcia funebre, op. 6. Klavir. Ljubljana, 23.3.1935. Osnutek rkp., svinčnik, [2] str., $22 \times 27$ cm; čtp., črnilo, str. 1-5, $21 \mathrm{~cm}$; čtp., črnilo, [3] str., $31 \mathrm{~cm}$. Naslov na rokopisu: Marche funebre, op. 9; na drugi strani v črtovju: Koračnica kavkaških poglavarjev. Prvemu čistopisu je priključena I. [Prva] sonata, op. 7. Posvetilo v kazalu prvega čistopisa: Dedicato al mio padre.

Med $G$ in H. Oboa, harfa. Rateče, 29.9.1982. Partitura, rkp., svinčnik, 4 str., 43 cm; čtp., flomaster, 14 str., $36 \mathrm{~cm}$. Naslov na čistopisu: Med G in H za oboo in harfo.

Meditatio de Sancta Trinitate. Orgle. Ljubljana, 24.11.1988. Rkp., svinčnik, 3 str., 43 cm; čtp., flomaster, 9 str., $35 \mathrm{~cm}$. Naslov na čistopisu: Meditatio de Sancta Trinitate za orgle.

Mehurčki

gl. Iz "Cicibana" za mladinski zbor

Menuet

gl. Suita za 2 violini, violončelo in godalni orkester

Menuet, klavir štiriročno

gl. Suita za 2 violini, violončelo in godalni orkester 


\section{MUZIKOLOŠKI ZBORNIK • MUSICOLOGICAL ANNUAL XXXV}

Mestni promet, mladinski zbor

gl. Kanoni za 2 ali 3 glasove

Miniature za flavto in gambo. Ljubljana, 15.3.1985. Partitura, rkp., svinčnik, 5 str., 43 cm; čtp., flomaster, 12 str., $36 \mathrm{~cm}$.

Miniature za klavir. Ljubljana, 7.11.1945. Rkp., svinčnik, 13 str., 31 cm; čtp., črnilo, 37 str., 34 cm; čtp., črnilo, 37 str., $32 \mathrm{~cm}$. Vsebina: Allegro, Largo, Allegretto, Vivace - Presto, Tempo di marcia, Andante moderato, Adagio molto, Maestoso, Vivacissimo, Presto.

Natis: $\quad$ Ljubljana, Savez kompozitora Jugoslavije - Društvo slovenskih skladateljev, 1955. 32 str., 32 $\mathrm{cm}$. (Edicije Društva slovenskih skladateljev, 5).

Delni natis: Miniatura (Allegretto). - v: Slovenske klavirske skladbe za mladino. VI. album. Izbrali in uredili Zorka Bradačeva in Silva Hrašovčeva. Ljubljana, Državna založba Slovenije, 1949. Str. 28-29.

Priredba: Iz Miniatur za klavir. Violina, klavir. Ljubljana, 12.11.1949. Partitura, rkp., svinčnik, 4 str., 31 cm. Vsebina: Pastoral (III., Allegretto), Uspavanka (VI., Andante moderato), Koračnica (V., Tempo di marcia). Naslov v B. Loparnik, Biti skladatelj, pogovori s Primožem Ramovšem; Ljubljana, Slovenska matica, 1984; str. 258: Tri miniature za violino in klavir.

Natis: $\quad$ Tri miniature za violino in klavir. - v: Slovenska glasbena revija 3/1955, 1-2, 72-78.

Delni natis: Pastoral; Koračnica. - v: Slovenski skladatelji mladim violinistom. Skladbe za violino in klavir. Zv. 1. Izbor in redakcija violinskega parta Tomaž Lorenz. Ljubljana, Državna založba Slovenije, 1982. Str. 27-31.

Miniature za solo violino. Roma, 5.5.1942. Rkp., svinčnik, 2 str., $33 \mathrm{~cm}$; čtp., črnilo, 5 str., $31 \mathrm{~cm}$.

Minnelied

gl. Ewig treu

Missa in Mi-mag[g]iore (E-dur), op. 9. Mešani zbor, orgle. [Ljubljana], ?. Nedokončano. Partitura, rkp., črnilo, 2 str., $31 \mathrm{~cm}$.

Mladinske pesmi. Besedilo ?. [Ljubljana], 1944. Pogrešano. Popisano po: B. Loparnik, Biti skladatelj, pogovori s Primožem Ramovšem; Ljubljana, Slovenska matica, 1984; str. 256.

Mladinske skladbe za Orffov instrumentarij. Ljubljana, 28.7.-1.8.1962. Partitura, rkp., svinčnik, 10 str., 31 $\mathrm{cm}$. Vsebina: Uspavanka, Kanon, Ura, Fanfara, Koračnica, Kitajska pesem, Afriški ples, Pastoral, Ples lutke, Finale, Dež, Žalna koračnica, Pesem iz Tuve.

Delni natis: Ples lutke; Ura. - v: Grlica, 9/1963, 2, notni del 21-23.

Molekule za klavir. Ljubljana, 21.11.1978. Rkp., svinčnik, 3 str., $43 \mathrm{~cm}$; čtp., flomaster, $8 \mathrm{str} ., 36 \mathrm{~cm}$.

Momenti riflessivi, op. 27. Orkester. Ljubljana, 25.12.1937. Partitura, čtp., črnilo, 52 str., 35 cm.

Monolog za violončelo solo. Ljubljana, 30.10.1962. Rkp., svinčnik, 2 str., $26 \mathrm{~cm}+$ zapis tonske serije, [1] str., $5 \times 17 \mathrm{~cm}$; čtp. (matrica), flomaster, 4 str., $34 \mathrm{~cm}$.

Natis: Monolog za violončelo. Ljubljana, [samozaložba], 1962.4 str., 33 cm. Posvetilo: Ediju Majaronu.

La mort de loup, op. 28. Simfonična pesnitev. Orkester. [Ljubljana, 1938]. Nedokončano. Partitura, čtp., črnilo, 8 str., $34 \mathrm{~cm}$.

Motet za bariton in orgle

gl. Deus Israël conjungat vos

Motetto

gl. Beati immaculati, ženski zbor, orgle

Mouvement musical con fuga, op. 16. Orkester. [Ljubljana], 1936. Partitura, čtp., črnilo, 66 str., $34 \mathrm{~cm}+3$ parti à 2 str., 2 parta à 3 str., 4 parti à 4 str., $32 \mathrm{~cm} ; 5$ partov à 5 str., $34 \mathrm{~cm}$.

Mouvement sonatique, op. 18. Klavir. [Ljubljana], 1937. Čtp., črnilo, $9 \mathrm{str}$., $31 \mathrm{~cm}$.

Mouvement symphonique no. 3, op. 20. Orkester. [Ljubljana], 1937. Partitura, čtp., črnilo, 38 str., $34 \mathrm{~cm}$.

Mouvements symphoniques no. 1 et 2, op. 15. Orkester. [Ljubljana], 1936. Partitura, čtp., črnilo, 84 str., 35 $\mathrm{cm}$. 


\section{MUZIKOLOŠKI ZBORNIK • MUSICOLOGICAL ANNUAL XXXV}

Mrak: Chrysippos. Scenska glasba za kljunasto flavto. Ljubljana, 30.5 .1987 . Rkp., svinčnik, 3 str., $43 \mathrm{~cm}$. Mrtvaški ples. [Filmska glasba]. Orkester. Ljubljana, 19.11.1957. Partitura, rkp., svinčnik, 23 str., $43 \mathrm{~cm}$. Režija France Kosmač.

Musica funebre. Orkester. Ljubljana, 7.11.1941. Particella, rkp., svinčnik, 5 str., 34 cm; partitura, čtp., črnilo, 27 str., $34 \mathrm{~cm}$.

Musiques funèbres. Orkester. Ljubljana, 18.3.1955. Particella, rkp., svinčnik, 20 str., 31 cm; partitura, čtp., 62 str., $35 \mathrm{~cm}$. Nadnaslov na čistopisu: Poeme dramatique. Posvetilo: Albi v spomin! Čistopis se nahaja v arhivu Slovenske filharmonije.

Natisa: Zagreb, Savez kompozitora Jugoslavije, 1963. Partitura, 50 str., $33 \mathrm{~cm}$. (Edicije kompozitora Jugoslavije). IZOD - 64 .

Ljubljana, Društvo slovenskih skladateljev; Köln, Musikverlage Hans Gerig, 1977. Partitura, 48 str., $21 \mathrm{~cm}$. (Edicije Društva slovenskih skladateljev, 426). HG 683. Prevzeto v založbo Breitkopf und Härtel, Wiesbaden.

Na Balkanu. Množična pesem. Dvoglasno. Besedilo Štefan Lazić. [Ljubljana, 1947]. Rkp., svinčnik, str. [1], 36 cm. Priključeno: Zidari; Na sve načine.

Na sve načine. Enoglasno. Osnutek? Besedilo?. [Ljubljana, 1947]. Rkp., svinčnik, str. [2], 36 cm. Priključeno k: Na Balkanu.

Nanga - Parbat za sopransko kljunasto flavto. Ljubljana, 23.5.1990. Rkp., svinčnik, [1] str., 43 cm; čtp., flomaster, [1] str., $36 \mathrm{~cm}$. Čistopis je popisan po kseroksni kopiji. Posvetilo: Urbanu Golobu!

Nasprotja za flavto in orkester. Ljubljana, 10.5.1969. Partitura, rkp., svinčnik, 62 str., 31 cm; čtp., črnilo, 122 str., $43 \mathrm{~cm}$. Čistopis se nahaja v Društvu slovenskih skladateljev.

Ne bojiva se. Dva klavirja. Ljubljana, 23.5.1995. Partitura, rkp., svinčnik, 4 str., 43 cm; čtp., flomaster, 11 str., $33 \mathrm{~cm}$. Naslov na čistopisu: Ne bojiva se za 2 klavirja.

(Ne) - simetrija za klavir. Ljubljana, 10.5.1965. Rkp., svinčnik, [1] str., 30 cm; čtp. (matrica), svinčnik, kemični svinčnik, [3] str., $35 \mathrm{~cm}$.

Natis: $\quad$ Ljubljana, [samozaložba], 1965. [3] str., $34 \mathrm{~cm}$. Čelni naslov: (Non)-Symetrie pour piano.

Nekoliko drugače. Pihalni orkester. Ljubljana, 4.8.1987. Partitura, rkp., svinčnik, 25 str., $43 \mathrm{~cm}$.

Natis: $\quad$ Maribor, Hartman, 1990. Partitura, 41 str., $30 \mathrm{~cm}+42$ partov ([87] str.). 01000435.

Nevihta, op. 19. Simfonična pesnitev. Orkester. [Ljubljana], 1937. Partitura, čtp., črnilo, 12 str., 35 cm.

Nezadostno

gl. Ocene za klavir

Nihanja. Flavta, komorni ansambel. Ljubljana, 28.2.1967. Partitura, rkp., svinčnik, 24 str., 31 cm; čtp., črnilo, 59 str., $31 \mathrm{~cm}$. Naslov na čistopisu: Nihanja za flavto, idiofone in kordofone. Čistopis se nahaja $\mathrm{v}$ Društvu slovenskih skladateljev.

Nihil obstat. Klavir. Ljubljana, 1.9.1984. Rkp., svinčnik, 3 str., 43 cm; čtp., flomaster, 7 str., 36 cm. Naslov na čistopisu: Nihil obstat za klavir.

NMF. Klavir. Ljubljana, 14.2.1990. Rkp., svinčnik, 4 str., 43 cm; čtp., flomaster, 12 str., 35 cm. Naslov na čistopisu: NMF za klavir.

NN. Klavir. [Ljubljana], 1958. Rkp., svinčnik, str. [2], $31 \mathrm{~cm}$. Priključeno k: Zvonovi zvonijo.

Noč prihaja, op. 22. Glas, klavir. Besedilo Ivan Cankar. Ljubljana, 2.7.1937. Partitura brez besedila, rkp., črnilo, [1] str., $35 \mathrm{~cm}$; čtp., črnilo, 3 str., $34 \mathrm{~cm}$; čtp., črnilo, 5 str., $31 \mathrm{~cm}+2$ parta za violino, à [1] str., 31 $\mathrm{cm}, 35 \mathrm{~cm}$ (na hrbtni strani vaja iz harmonije, svinčnik). Na hrbtni strani rokopisa: 4. stavek, Adagio maestoso - Allegro molto e vivace; prečrtano.

Prepesnitev: Cala la notte. Glas, klavir. Di Ivan Cankar. Traduzione di Silvester Škerl. Čtp., črnilo, 7 str., $34 \mathrm{~cm}$.

Nokturno

gl. Bagatele za klavir 


\section{MUZIKOLOŠKI ZBORNIK • MUSICOLOGICAL ANNUAL XXXV}

Nokturno. Komorni orkester. Ljubljana, 3.6.1977. Partitura, rkp., svinčnik, 14 str., $43 \mathrm{~cm}$.

Natis: $\quad$ Nokturno za komorni orkester. Ljubljana, Društvo slovenskih skladateljev, 1979. Partitura, 33 str., $29 \mathrm{~cm}$. (Edicije Društva slovenskih skladateljev, 885). Reprodukcija skladateljevega rokopisa.

Nokturno. Kvartet flavt. Ljubljana, 22.10.1983. Partitura, rkp., svinčnik, 3 str., 43 cm; čtp., flomaster, 10 str., $36 \mathrm{~cm}$. Naslov na čistopisu: Nokturno za 4 flavte.

Natis: $\quad$ Nokturno za 4 flavte. Ljubljana, Društvo slovenskih skladateljev; Leipzig - Dresden, Edition Peters, 1985. Partitura, 7 str., 30 cm. (Edicije Društva slovenskih skladateljev, 1140). EP 10446. Ponatis z novimi platnicami založbe Peters; naslov: Nokturno für 4 Flöten.

Nokturno für 4 Flöten

gl. Nokturno, kvartet flavt

Nokturno za violo in klavir. Ljubljana, 13.10.1959. Partitura, rkp., svinčnik, 3 str., 31 cm; čtp., črnilo, 11 str., $30 \mathrm{~cm}$.

Natis: Ljubljana, [samozaložba], 1963. Partitura, 8 str., $31 \mathrm{~cm}+1$ part, 3 str., $30 \mathrm{~cm}$. Na naslovnici parta viole: Redakcija Srečko Zalokar.

(Non)-Symetrie pour piano

gl. (Ne)-simetrija za klavir

Nuances za kontrabas in godalni kvartet. Ljubljana, 27.3.1975. Partitura, rkp., svinčnik, 9 str., 43 cm. Posvetilo: Ljupču Samardžiskemu!

Ob klavirju. Klavir. Ljubljana, 19.8.1989. Rkp., svinčnik, 3 str., 43 cm; čtp., flomaster, 8 str., 35 cm. Naslov na čistopisu: Ob klavirju za klavir.

Ob sliki Maksima Sedeja. Klavir. Ljubljana, 13.5.1997. Rkp., svinčnik, 1 str., $43 \mathrm{~cm}$.

Ocene za klavir. Ljubljana, 20.1.1968. Rkp., svinčnik, 5 str., 31 cm; čtp. (matrica), flomaster, 7 str., $34 \mathrm{~cm}$. Posvetilo: Klemenu! Stavki: Odlično, Prav dobro, Dobro, Zadostno, Nezadostno.

Natis: Ljubljana, [samozaložba], $1968.7 \mathrm{str} ., 33 \mathrm{~cm}$. Reprodukcija skladateljevega rokopisa.

Octoginta. Klavir. Ljubljana, 6.11.1989. Rkp., svinčnik, 2 str., 43 cm; čtp., flomaster, 8 str., 35 cm. Naslov na čistopisu: Octoginta za klavir. Posvetilo: Marijanu Lipovšku vezilo za 80 letnico!

Od - do. Klavir. Ljubljana, 20.7.1993. Rkp., svinčnik, 3 str., 43 cm; čtp., flomaster, 8 str., 35 cm. Naslov na čistopisu: Od - do za klavir. Posvetilo: Hinku Haasu!

Odgovori. Pihalni kvintet. Ljubljana, 23.8.1974. Partitura, rkp., svinčnik, 7 str., 43 cm; čtp., črnilo, 27 str., 36 $\mathrm{cm}$. Naslov na čistopisu: Odgovori za pihalni kvintet. Čistopis se nahaja v Društvu slovenskih skladateljev.

Natis: Odgovori za pihalni kvintet. Ljubljana, Društvo slovenskih skladateljev; Köln, Musikverlage Hans Gerig, 1978. Partitura, 12 str., 35 cm. (Edicije Društva slovenskih skladateljev, 854). HG 1337. Prevzeto v založbo Breitkopf und Härtel, Wiesbaden.

Odlično

gl. Ocene za klavir

Odmevi für Flöte und Orchester gl. Odmevi za flavto in orkester

Odmevi za flavto in orkester. Ljubljana, 3.8.1965. Partitura, rkp., svinčnik, 38 str., 31 cm; čtp., črnilo, 109 str., $31 \mathrm{~cm}$. Čistopis se nahaja v Društvu slovenskih skladateljev.

Natis: $\quad$ Ljubljana, Društvo slovenskih skladateljev; Köln, Musikverlage Hans Gerig, 1973. Partitura, 79 str., $33 \mathrm{~cm}$. (Edicije Društva slovenskih skladateljev, 532). HG 1048. Ponatis z novimi platnicami založbe H. Gerig; naslov: Odmevi für Flöte und Orchester. Prevzeto v založbo Breitkopf und Härtel, Wiesbaden.

Opus $X$. Komorni ansambel. Ljubljana, 6.2.1979. Partitura, rkp., svinčnik, $10 \mathrm{str}$., $43 \mathrm{~cm}+$ navodila, tipkopis, [1] str., $30 \mathrm{~cm}$; čtp., flomaster, 19 str., 22 x $30 \mathrm{~cm}$. Čistopis je popisan po kseroksni kopiji. Posvetilo: For Australia Felix! 


\section{MUZIKOLOŠKI ZBORNIK • MUSICOLOGICAL ANNUAL XXXV}

Ora et labora. Orgle. Ljubljana, 19.8.1991. Rkp., svinčnik, 5 str., 43 cm; čtp., flomaster, 14 str., 36 cm. Naslov na čistopisu: Ora et labora za orgle. Čistopis je popisan po kseroksni kopiji. Posvetilo na rokopisu: Dr. Andreju Capudru!

Organofonia. Orgle, orkester. Ljubljana, 8.7.1982. Partitura, rkp., svinčnik, 43 str., 43 cm; čtp., črnilo, 63 str., $43 \mathrm{~cm}$. Naslov na čistopisu: Organofonia za simfonični orkester. Čistopis se nahaja v Društvu slovenskih skladateljev.

Orpheus in Euridika, op. 4. Opera v dveh dejanjih. Besedilo Primož Ramovš. [Ljubljana, 1934]. Partitura, rkp., svinčnik, 1 zv., str. 1-4, 2. zv., str. 5-105, 3. zv., str. 106-125, 34 cm (1. zv.), $31 \mathrm{~cm}$ (2. in 3. zv.). Na platnicah tretjega zvezka: op. 10b. Na prvi strani tretjega zvezka: op. 10 b. Uvertura "Čudodelna roka" + listek: Koral v c-molu, à Dragica Repe, Canto ferno in Do-minore, op. 10a, 7 x 24 cm.

80 [Osemdeset]. Viola. Ljubljana, 29.4.1997. Rkp., svinčnik, 1 str., 43 cm; čtp., flomaster, 5 str., 35 cm. Naslov na čistopisu: 80 za violo. Čistopis je popisan po kseroksni kopiji. Posvetilo: Srečku Zalokarju!

Osmerica. Dva klavirja štiriročno. Ljubljana, 15.9.1995. Partitura, rkp., svinčnik, 11 str., 43 cm; čtp., flomaster, 35 str., 36 cm (str. 1-26 in 35), 33 cm (str. 27-34). Rokopis je popisan po kseroksni kopiji. Naslov na čistopisu: Osmerica za 2 klavirja štiriročno.

Ostinato

gl. Šest malih preludijev za klavir

Ostinato. Klarinet, klavir. Ljubljana, 21.12.1992. Partitura, rkp., svinčnik, 2 str., 43 cm; čtp., flomaster, 5 str., $36 \mathrm{~cm}$. Naslov na čistopisu: Ostinato za klarinet in klavir.

Natis: $\quad$ Slovenski skladatelji mladim klarinetistom. 1. natis. Radovljica, Didakta, 1993. Str. 27-29.

Ot'če naš. Moški zbor. Roma, 7.5.1943. Partitura, rkp., svinčnik, 3 str., 33 cm; čtp., črnilo, 9 str., 34 cm.

Naslov je v cirilici.

Natis: $\quad$ Cerkveni glasbenik 78/1985, 1-3, notna priloga 1-8.

Ouverture

gl. Suita za 2 violini, violončelo in godalni orkester

Partitura. Kvartet (kljunasta flavta, violina, violončelo, klavir). Ljubljana, 22.11.1975. Partitura, rkp., svinčnik, 16 str., $43 \mathrm{~cm}$.

Pastoral, 2 flavti, trikotnik, činele

gl. Mladinske skladbe za Orffov instrumentarij

Pastoral, violina, klavir

gl. Miniature za klavir

Pastoral za blokflavto in klavir. Ljubljana, 9.12.1971. Partitura, rkp., svinčnik, str. 1-2, 34 cm. Priključeno: Uspavanka.

Pastorale

gl. Mala suita za klavir

Pastorale. Klavir. Ljubljana, 1.3.1944. Rkp., svinčnik, str. 1-2, 34 cm. Priključeno k: Preludij.

Natis: $\quad$ Preludij, pastoral, tokata za klavir. V Ljubljani, Akademska založba, 1944. Str. 5-7, 31 cm. A. Z. 5.

P[atru] Martinu 50 not za 50 let. Orgle. Rateče, 18.9.1963. Rkp., svinčnik, [1] str., $31 \mathrm{~cm}$.

Pax et bonum. Orgle. Ljubljana, 2.12.1988. Rkp., svinčnik, 5 str., 43 cm; čtp., flomaster, 15 str., 35 cm. Naslov na čistopisu: Pax et bonum za orgle. Čistopis je popisan po kseroksni kopiji.

Paževa usoda, op. 3. Opera v štirih dejanjih. Besedilo Primož in Alba Ramovš. Ljubljana, 10.3.1934. Partitura, rkp., svinčnik, 62 str., 31 cm. Priključeno: Potpourri Bizet-jeve opere "Carmen".

Pedale tenuto. Klavir. Ljubljana, 29.5.1989. Rkp., svinčnik, 3 str., 43 cm; čtp., flomaster, 8 str., 35 cm. Naslov na čistopisu: Pedale tenuto za klavir.

Pentafonia. Kljunasta flavta, godalni kvartet. Ljubljana, 28.11.1990. Partitura, rkp., svinčnik, 11 str., 43 cm; čtp., flomaster, 33 str., $36 \mathrm{~cm}$. Naslov na čistopisu: Pentafonia za kljunasto flavto in godalni kvartet. 


\section{MUZIKOLOŠKI ZBORNIK • MUSICOLOGICAL ANNUAL XXXV}

Pentagon. Pihalni kvintet in 4 orkestrske skupine. Rateče, 21.10.1977. Partitura, rkp., svinčnik, 56 str., 43 cm; čtp., črnilo, 109 str., $42 \mathrm{~cm}$. Naslov na čistopisu: Pentagon za pihalni kvintet in 4 orkestrske skupine. Čistopis se nahaja v Društvu slovenskih skladateljev.

Pentektasis za klavir. Ljubljana, 15.2.1963. Rkp., svinčnik, 6 str., $31 \mathrm{~cm}+$ zapis tonskih serij, svinčnik, [1] str., 18 x $24 \mathrm{~cm}$; čtp., črnilo, 6 str., $36 \mathrm{~cm}$.

Natis: Ljubljana, [samozaložba], $1963.6 \mathrm{str} ., 31 \mathrm{~cm}$.

Per aspera ad astra. Orkester. Ljubljana, 29.4.1991. Partitura, rkp., svinčnik, 54 str., 43 cm; čtp., črnilo, 69 str., $42 \mathrm{~cm}$. Naslov na čistopisu: Per aspera ad astra za simfonični orkester. Čistopis se nahaja v Društvu slovenskih skladateljev.

Perchè. Klavir. Ljubljana, 6.11.1993. Rkp., svinčnik, 3 str., 43 cm; čtp., flomaster, 9 str., 36 cm. Naslov na čistopisu: Perchè per pianoforte. Posvetilo: À Paolo Restani!

Pesem iz Tuve, zvončki, trikotnik, činele, boben gl. Mladinske skladbe za Orffov instrumentarij

Pet miniatur za flavto in klarinet. Ljubljana, 11.2.1961. Partitura, rkp., svinčnik, $5 \mathrm{str} ., 31 \mathrm{~cm}+$ zapis tonske serije, [1] str., $31 \mathrm{~cm}$.

Pet minut za violončelo in čembalo. Rateče, 3.10.1979. Partitura, rkp., svinčnik, 4 str., 43 cm; čtp., flomaster, 13 str., $36 \mathrm{~cm}$. Naslov na čistopisu: Pet minut za violončelo in čembalo.

Petite phantasie, op. 24. Klavir. [Ljubljana], 1937. Čtp., črnilo, 2 str., $34 \mathrm{~cm}$.

Pianissimo. Komorni ansambel (flavta, rog, violončelo, kontrabas, klavir). Ljubljana, 9.11.1974. Partitura, rkp., svinčnik, 7 str., 43 cm. Posvetilo: Ansamblu "Slavko Ostercu!

Pièce symphonique

gl. Simfonija za godalni orkester, op. 17[b]

Pihalni diptih. Pihalni trio. Ljubljana, 9.10.1997. Partitura, rkp., svinčnik, 5 str., 43 cm; čtp., flomaster, 13 str., $33 \mathrm{~cm}$. Naslov na čistopisu: Pihalni diptih za pihalni trio.

Pihalni kvintet. Ljubljana, 18.4.1959. Partitura, rkp., svinčnik, 13 str., $31 \mathrm{~cm}$.

Natis: $\quad$ Ljubljana, Društvo slovenskih skladateljev, 1980. Partitura, 19 str., $21 \mathrm{~cm}$. (Edicije Društva slovenskih skladateljev, 891).

Pihalni kvintet, op. 21. [Ljubljana], 1937. Partitura, čtp., črnilo, 13 str., 34 cm.

Pihalni trio

gl. Trio za 2 oboi (oboo in klarinet) in fagot

Pika na i. Klavir. Ljubljana, 12.4.1995. Rkp., svinčnik, 2 str., 43 cm; čtp., flomaster, 6 str., 36 cm. Naslov na čistopisu: Pika na i za klavir.

Pismo. Orkester. Ljubljana, 19.9.1989. Partitura, rkp., svinčnik, 39 str., 43 cm; čtp., črnilo, 59 str., $42 \mathrm{~cm}$. Naslov na čistopisu: Pismo za simfonični orkester. Posvetilo: Andi! Čistopis se nahaja v Društvu slovenskih skladateljev.

PL. Klavir. [Ljubljana], 1995. Pogrešano. Popisano po skladateljevem seznamu del.

Plautus: Dvojčka. Scenska glasba. Komorni orkester. Ljubljana, 13.4.1955. Partitura, rkp., svinčnik, 35 str., $43 \mathrm{~cm}+12$ partov, čtp., črnilo, à 5, 6, oz. 9 str., $35 \mathrm{~cm}$. Režija Jože Gale.

Ples, mladinski zbor

gl. Kanoni za 2 ali 3 glasove

Ples lutke, zvončki, metalofon

gl. Mladinske skladbe za Orffov instrumentarij

Ples podzemskih duhov, op. 11. Simfonična pesnitev v štirih stavkih. Mali orkester. [Ljubljana], 1936. Partitura, čtp., črnilo, 92 str., $34 \mathrm{~cm}$.

+:- [Plus proti minus] za klavir in godala. Ljubljana, 17.6.1966. Partitura, rkp., svinčnik, 23 str., $31 \mathrm{~cm}+$ part za klavir, čtp., 13 str., $34 \mathrm{~cm}$. Čistopis je popisan po kseroksni kopiji.

Po koncertu. Harfa. Ljubljana, 20.9.1993. Rkp., svinčnik, 1 str., 43 cm; čtp., flomaster, 4 str., 36 cm. Naslov na čistopisu: Po koncertu za harfo. Posvetilo: Mojci Zalokar! 


\section{MUZIKOLOŠKI ZBORNIK • MUSICOLOGICAL ANNUAL XXXV}

Po tipkah. Klavir. Ljubljana, 9.11.1978. Rkp., svinčnik, 3 str., 43 cm; čtp., flomaster, 8 str., 36 cm. Naslov na čistopisu: Po tipkah za klavir. Čistopis je popisan po kseroksni kopiji. Posvetilo: Marini Horakovi!

Pod gradom. Glas, klavir. Besedilo Simon Jenko. [Ljubljana, 1936 ali 1937]. Partitura, rkp., črnilo, str. 2-3, $35 \mathrm{~cm}$. Priključeno k: Vprašanje.

Poeme dramatique

gl. Musiques funèbres

Pogled. Kljunasta flavta, čembalo. Ljubljana, 6.3.1971. Partitura, rkp., svinčnik, 4 str., 43 cm. Milošu Pahorju in Dini Slama!

Pogovor za godalni kvartet. Rateče, 29.9.1979. Partitura, rkp., svinčnik, 7 str., 43 cm; čtp., flomaster, 13 str., $43 \mathrm{~cm}$.

Pogumno naprej. Klarinet, klavir. Ljubljana, 2.4.1992. Partitura, rkp., svinčnik, 4 str., 43 cm; čtp., flomaster, 13 str., $36 \mathrm{~cm}$. Naslov na čistopisu: Pogumno naprej za klarinet in klavir.

Pojoče strune. Dve violini, klavir. Ljubljana, 7.5.1994. Partitura, rkp., svinčnik, 7 str., 43 cm; čtp., flomaster, 15 str., $33 \mathrm{~cm}$. Naslov na čistopisu: Pojoče strune za 2 violini in klavir.

Poletje

gl. I. [Prva] sonata, op. 7

Poliptih. Orkester. Ljubljana, 18.7.1978. Partitura, rkp., svinčnik, 51 str., 43 cm; čtp., črnilo, 64 str., $42 \mathrm{~cm}$. Čistopis se nahaja v Društvu slovenskih skladateljev.

Polygram za violo in klavir. Ljubljana, 15.2.1968. Partitura, rkp., svinčnik, 4 str., 31 cm; čtp. (matrica), flomaster, 7 str., $36 \mathrm{~cm}$. Naslov na čistopisu: Polygram for viola and piano.

Natis: Polygram for viola and piano. Ljubljana, [samozaložba], 1968. Partitura, 7 str., 35 cm. Reprodukcija skladateljevega rokopisa.

Pomlad

gl. I. [Prva] sonata, op. 7

Portret za harfo in komorni ansambel. Ljubljana, 5.11.1968. Partitura, rkp., svinčnik, 17 str., 31 cm; čtp., črnilo, 43 str., $31 \mathrm{~cm}$. Čistopis se nahaja v Društvu slovenskih skladateljev.

Natis: Portrait za harfo in komorni ansambel. Ljubljana, Društvo slovenskih skladateljev, 1974. Partitura, 39 str., $35 \mathrm{~cm}$. (Edicije Društva slovenskih skladateljev, 584).

Potoki. Flavta. Ljubljana, 13.11.1989. Rkp., svinčnik, 2 str., 43 cm; čtp., flomaster, 5 str., 35 cm. Naslov na čistopisu: Potoki za flavto. Posvetilo: Tadeji!

Potpourri Bizet-jeve opere "Carmen.. Violina, dva klavirja, tolkala. [Ljubljana, 1934?]. Partitura, nepopolno, rkp., svinčnik, 16 str. (od zadnje strani zvezka proti začetku), $31 \mathrm{~cm}+$ part za violino I, svinčnik, 2 str., $31 \mathrm{~cm}+$ part za violino II, svinčnik, 2 str., $31 \mathrm{~cm}$. Priključeno k: Paževa usoda, op. 3.

Potpourri slovenskih narodnih pesmi, op. 5. Dve violini, klavir štiriročno. [Ljubljana, 15.2.1934]. Partitura, rkp., svinčnik, 28 str., $16 \times 24 \mathrm{~cm}$.

Praeludium, flavta, harfa

gl. Kongresni avizo

Prav dobro

gl. Ocene za klavir

Preludij

gl. Mala suita za klavir

Preludij. Klavir. Ljubljana, 21.2.1944. Rkp., svinčnik, str. 1, 34 cm. Priključeno: Pastorale; Tokata.

Natis: $\quad$ Preludij, pastoral, tokata za klavir. V Ljubljani, Akademska založba, 1944. Str. 3-4, 31 cm. A. Z. 5.

Preludij in fuga za orgle. Ljubljana, 29.1.1951. Rkp., svinčnik, $6 \mathrm{str} ., 31 \mathrm{~cm}$.

Preludij in fuga za tolkala. Ljubljana, 5.2.1952. Partitura, rkp., svinčnik, 7 str., $31 \mathrm{~cm}$.

Preludij in vrnitve za klavir. Ljubljana, 11.1.1966 (I. stavek), 26.2.1966 (II.-VI. stavek). Rkp., svinčnik, 35 str., $31 \mathrm{~cm}$.

Delni natis: 


\section{MUZIKOLOŠKI ZBORNIK • MUSICOLOGICAL ANNUAL XXXV}

Präludium (I. stavek). - v: Neue Jugoslawische Klaviermusik. Heft 2. Herausgegeben Rudolf Lück. Köln, Musikverlag Hans Gerig, 1966. HG 552. Str. 15-17.

Preludij za violino in klavir. [Ljubljana], 1955. Pogrešano. Popisano po: B. Loparnik, Biti skladatelj, pogovori s Primožem Ramovšem; Ljubljana, Slovenska matica, 1984; str. 260 in po skladateljevem seznamu del.

Pro tribus. Trio (flavta, kontrabas, klavir). Ljubljana, 12.11.1992. Partitura, rkp., svinčnik, 8 str., 43 cm; čtp., flomaster, 13 str., $42 \mathrm{~cm}$. Naslov na čistopisu: Pro tribus za flavto, kontrabas in klavir.

Profili. Orkester. Ljubljana, 17.7.1964. Particella, rkp., svinčnik, 53 str., 31 cm; partitura, čtp., črnilo, 119 str., $42 \mathrm{~cm}$. Čistopis se nahaja v Društvu slovenskih skladateljev.

Prolog - dialog - epilog. Trio (flavta, klarinet, fagot). Ljubljana, 13.12.1966. Partitura, rkp., svinčnik, 8 str., $31 \mathrm{~cm}$; čtp. (matrica), flomaster, 15 str., $36 \mathrm{~cm}$. Naslov na čistopisu: Prolog, dia[log], epi[log] za flavto, klarinet, fagot.

Natis: $\quad$ Prolog, dia[log], epi[log] za flavto, klarinet, fagot. Ljubljana, [samozaložba], 1966. Partitura, 15 str., $33 \mathrm{~cm}$.

\section{1. [Prva] simfonija}

gl. Simfonija $I$.

I. [Prva] sonata, op. 7. Štirje letni časi. Klavir. Nedokončano. Ljubljana, [23.3.1935]. Čtp., črnilo, str. 5-19, $21 \mathrm{~cm}$. Stavka sonate: Pomlad, Poletje; tretji in četrti stavek nista bila napisana. Posvetilo v kazalu čistopisa: Dedicato alla mia madre. Priključeno k: Marcia funebre, op. 6.

Psalm 50 za ženski zbor in orgle. Ljubljana, 20.12.1948. Partitura, rkp., svinčnik, 6 str., $31 \mathrm{~cm}+$ odpev, črnilo, [1] str., $16 \times 22 \mathrm{~cm}$.

Natis: $\quad$ Psalm 50. [S. 1., s. n.], 1949. 3 parti à 2 str., $34 \mathrm{~cm}$.

Pušeljc. Klavir. Ljubljana, 6.9.1996. Rkp., svinčnik, 2 str., 43 cm; čtp., flomaster, 7 str., 36 cm. Naslov na čistopisu: Pušeljc za klavir. Posvetilo: Niki Lendero!

Quadruplum za orgle štiriročno. Rateče, 9.10.1982. Partitura, rkp., svinčnik, 8 str., 43 cm; čtp., flomaster, 25 str., $36 \mathrm{~cm}$. Čistopis je popisan po kseroksni kopiji. Posvetilo: Mariji Řihánkovi!

Quatre pièces symphoniques za godalni orkester, op. $17 b$

gl. Simfonija za godalni orkester, op. 17 [b]

Quatre thèmes pour M. Albrespic. Enoglasno. Ljubljana, 2.8.1970. Rkp., svinčnik, [1] str., 14 x $24 \mathrm{~cm}$.

Quinque sumus. Marimbafon, godalni kvartet. Ljubljana, 6.6.1997. Partitura, rkp., svinčnik, 7 str., 43 cm; čtp., flomaster, 12 str., $43 \mathrm{~cm}$. Naslov na čistopisu: Quinque sumus per marimba e quartetto d'archi. Posvetilo: À Fabian Perez Tedesco.

Radius sonans. Angleški rog, klavir. Ljubljana, 23.11.1994. Partitura, rkp., svinčnik, 4 str., 43 cm; čtp., flomaster, 10 str., $33 \mathrm{~cm}$. Naslov na čistopisu: Radius sonans za angleški rog in klavir. Posvetilo: Ireni Pahor!

Ravel: Bolero. Priredba za komorni ansambel. [Ljubljana, verjetno 1941]. Particella, čtp., črnilo, 3 str., 33 $\mathrm{cm}+1$ part za kljunasto flavto in rog, 2 str., $33 \mathrm{~cm}+1$ part za klarinet in fagot, 2 str., $33 \mathrm{~cm}+1$ part za violino?, 1 str., $25 \mathrm{~cm}+1$ part za kontrabas, [1] str., $22 \times 26 \mathrm{~cm}+1$ part za saksofon, 1 str., $17 \times 24 \mathrm{~cm}+1$ part za trobento, 1 str., $17 \times 24 \mathrm{~cm}+1$ part za trobento, [1] str., $8 \times 24 \mathrm{~cm}$.

Reminiscence 37 - 77. Godalni trio. Ljubljana, 30.12.1977. Partitura, rkp., svinčnik, 5 str., 43 cm; čtp., flomaster, 20 str., $36 \mathrm{~cm}$. Naslov na čistopisu: Reminiscence $37-77$ za godalni trio. Posvetilo: À Trio Labacense!

Natis: $\quad$ Reminiscences $37-77$ za violino, violo in violončelo. Ljubljana, Društvo slovenskih skladateljev, 1981. Partitura, 9 str., $35 \mathrm{~cm}$. (Edicije Društva slovenskih skladateljev, 990).

Repraesentatio. Trobenta, klavir. Ljubljana, 2.12.1992. Partitura, rkp., svinčnik, 6 str., 43 cm; čtp., flomaster, 15 str., $36 \mathrm{~cm}$. Naslov na čistopisu: Repraesentatio za trobento in klavir.

Requiem za deški glas, moški zbor in 11 instrumentov. Ljubljana, 20.2.1953. Partitura, rkp., svinčnik, 11 str., $31 \mathrm{~cm}$. Posvetilo: Atilu v spomin! 


\section{MUZIKOLOŠKI ZBORNIK • MUSICOLOGICAL ANNUAL XXXV}

Ricercare na Merküjevo temo za oboo in klavir. Ljubljana, 13.4.1957. Partitura, rkp., svinčnik, 7 str., $31 \mathrm{~cm}$ (str. 1-6), $25 \mathrm{~cm}$ (str. 7).

Natisa: Ricercare na témo Pavla Merkùja za oboo in klavir. Ljubljana, Savez kompozitora Jugoslavije Društvo slovenskih skladateljev, 1958. Partitura, 16 str., $32 \mathrm{~cm}+1$ part, 4 str., $32 \mathrm{~cm}$. (Edicije Društva slovenskih skladateljev, 59).

Ricercare na témo Pavla Merkùja za oboo in klavir. Ljubljana, Društvo slovenskih skladateljev, 1967. Partitura, 16 str., $30 \mathrm{~cm}+1$ part, 3 str., $29 \mathrm{~cm}$. (Edicije Društva slovenskih skladateljev, 172).

Ricercare per pianoforte. Roma, 5.1.1943. Rkp., svinčnik, 2 str., 34 cm; čtp., črnilo, 5 str., 34 cm.

Robbov vodnjak. Kljunasta flavta, zvončki, ksilofon. Ljubljana, 14.3.1998. Partitura, rkp., svinčnik, 1 str., 43 $\mathrm{cm}$; čtp., flomaster, [1] str., $43 \mathrm{~cm}$.

Rondeau za violino in kitaro. Ljubljana, 21.1.1978. Partitura, rkp., svinčnik, 4 str., 43 cm; čtp., flomaster, $14 \mathrm{str}$., $36 \mathrm{~cm}$.

Rondino za klavir. [Ljubljana], 1942. Pogrešano. Popisano po: B. Loparnik, Biti skladatelj, pogovori s Primožem Ramovšem; Ljubljana, Slovenska matica, 1984; str. 256.

Rondò variato za kontrabas in kitaro. Ljubljana, 8.4.1978. Partitura, rkp., svinčnik, 4 str., 43 cm; čtp., flomaster, 14 str., $36 \mathrm{~cm}$. Posvetilo: Ljupču Samardžiskemu!

Rondo za 2 klavirja in godalni orkester. Ljubljana, 9.8.1950. Particella, rkp., svinčnik, $11 \mathrm{str} ., 31 \mathrm{~cm}$.

Rondo za godalni orkester. Ljubljana, 13.11.1959. Particella, rkp., svinčnik, 4 str., $31 \mathrm{~cm}$.

Salpinx. Mala trobenta, klavir. Ljubljana, 30.8.1978. Partitura, rkp., svinčnik, 8 str., 43 cm; čtp., flomaster, 23 str., $36 \mathrm{~cm}$. Naslov na čistopisu: Salpinx za malo trobento in klavir.

Sarkazmi za klavir. Ljubljana, 30.4.1951. Rkp., svinčnik, [8] str., $31 \mathrm{~cm}$; čtp., črnilo, 29 str., $31 \mathrm{~cm}$.

Natisa: Ljubljana, samozaložba, 1953.20 str., $29 \mathrm{~cm}$.

Ljubljana, Društvo slovenskih skladateljev; Köln, Musikverlage Hans Gerig, 1976. 20 str., 35 cm. (Edicije Društva slovenskih skladateljev, 273). HG 1203. Prevzeto v založbo Breitkopf und Härtel, Wiesbaden.

Saxofonia. Kvartet saksofonov. Ljubljana, 27.9.1995. Partitura, rkp., svinčnik, 6 str., 43 cm; čtp., flomaster, 13 str., $35 \mathrm{~cm}$. Naslov na čistopisu: Saxofonia za kvartet saxofonov.

Scherzo

gl. Bagatele za klavir

Scherzo

gl. Mala suita za klavir

Scherzo

gl. Sedem skladb za godalni orkester

Scherzo za klavir. Roma, 21.5.1942. Rkp., svinčnik, 3 str., 33 cm (str. 1-2), 17 x 24 cm (str. 3).

Natis: V Ljubljani, Akademska založba, 1943.9 str., $31 \mathrm{~cm}$.

Scherzo za klavir in godalni orkester. Ljubljana, 22.9.1950. Particella, rkp., svinčnik, 7 str., $31 \mathrm{~cm}$; partitura, čtp., črnilo, 25 str., $35 \mathrm{~cm}$.

Natis: Ljubljana, Savez kompozitora Jugoslavije - Društvo slovenskih skladateljev, 1958. Partitura, 27 str., $32 \mathrm{~cm}$. (Edicije Društva slovenskih skladateljev, 62).

Sedem skladb za godalni orkester. Ljubljana, 4.6.1960. Particella, rkp., svinčnik, 12 str., 31 cm; partitura, čtp., črnilo, 25 str., $42 \mathrm{~cm}$. Naslov na čistopisu: Sedem skladb za godala. Posvetilo: Slovenskim orkestrom! Vsebina: Fanfara, Koral, Kanon, Scherzo, Arioso, Intermezzo, Tokata. Čistopis se nahaja v Društvu slovenskih skladateljev.

Delna priredba: Sonatina za godala. List z opombami za spremembe v instrumentaciji Sedmih skladb za godala. Ljubljana, 15.6.1962. Partitura, rkp., svinčnik, [1] str., $31 \mathrm{~cm}$. Stavki: Scherzo, Intermezzo, Tokata.

Septet. Pihalni septet (flavta, oboa, klarinet, fagot, trobenta, rog, trombon). Ljubljana, 30.9.1996. Partitura, rkp., svinčnik, 7 str., $43 \mathrm{~cm}$; čtp., flomaster, 21 str., $34 \mathrm{~cm}$. Čistopis je popisan po kseroksni kopiji. 


\section{MUZIKOLOŠKI ZBORNIK • MUSICOLOGICAL ANNUAL XXXV}

Septuaginta. Orgle. Ljubljana, 29.5.1990. Rkp., svinčnik, 6 str., $43 \mathrm{~cm}$ + navodila za uporabo registrov, svinčnik, $30 \mathrm{~cm}$; čtp., flomaster, 22 str., $36 \mathrm{~cm}$. Naslov na čistopisu: Septuaginta za orgle. Čistopis je popisan po kseroksni kopiji. Posvetilo na rokopisu: Nadškofu Alojziju Šuštarju!

Séquence des Séquences. Komorni ansambel. Ljubljana, 9.4.1974. Partitura, rkp., svinčnik, 11 str., $43 \mathrm{~cm}$. Posvetilo: À Cormel Ţaranu.

Shakespeare: Sen kresne noči. Prolog. Scenska glasba. Recitator, klavir. Ljubljana, 6.11., 11.12.1959. Rkp., svinčnik, 5 str., $31 \mathrm{~cm}$.

Signali za klavir in ansambel. Ljubljana, 17.4.1971. Partitura, rkp., svinčnik, 14 str., 43 cm; čtp., črnilo, 68 str., $36 \mathrm{~cm}$. Posvetilo na čistopisu: Aciju Bertonclju in ansamblu "Slavko Osterc" $Z$ Ivom Petrićem! Čistopis se nahaja v Društvu slovenskih skladateljev.

Simfonia orientale, op. 23. Orkester. Ljubljana, 1937. Partitura, čtp., črnilo, 28 str., $34 \mathrm{~cm}$.

Simfonični portret. Orkester. Ljubljana, 18.4.1972. Partitura, rkp., svinčnik, 39 str., 43 cm; čtp., flomaster, [115] str., $42 \mathrm{~cm}$. Posvetilo: Frideriku Baragi v vdanem prijateljskem spoštovanju! Čistopis se nahaja $\mathrm{v}$ Društvu slovenskih skladateljev.

Simfonietta. Orkester. Ljubljana, 12.11.1951. Particella, rkp., svinčnik, 43 str., 31 cm; partitura, čtp., 133 str., $31 \mathrm{~cm}$. Čistopis se nahaja v arhivu Slovenske filharmonije.

Natisa: $\quad$ Sinfonietta. Ljubljana, Savez kompozitora Jugoslavije - Društvo slovenskih skladateljev, 1956. Partitura, 112 str., $35 \mathrm{~cm}$. (Edicije Društva slovenskih skladateljev, 20).

Sinfonietta. Ljubljana, Savez kompozitora Jugoslavije - Društvo slovenskih skladateljev, 1965. Partitura, 112 str., $33 \mathrm{~cm}$. (Edicije Društva slovenskih skladateljev, 208).

Simfonija II. [druga]. Orkester. Ljubljana, 27.1.1944. Particella, rkp., svinčnik, 35 str., 34 cm; partitura, čtp., 181 str., 34 cm (str. 1-102), 31 cm (str. 103-181), vezano. "Naslov na platnicah čistopisa: 2. simfonija. Čistopis se nahaja v Društvu slovenskih skladateljev.

Simfonija med klavirjem in orkestrom. Ljubljana, 25.7.1970. Partitura, rkp., svinčnik, 51 str., 31 cm; čtp., črnilo, 115 str., $43 \mathrm{~cm}$. Čistopis se nahaja v Društvu slovenskih skladateljev.

Simfonija 68 [oseminšestdeset]. Orkester. Ljubljana, 23.7.1968. Particella, rkp., svinčnik, $61 \mathrm{str}, 31 \mathrm{~cm}$; čtp., črnilo, 111 str., $42 \mathrm{~cm}$. Čistopis se nahaja v Društvu slovenskih skladateljev.

Natis: $\quad$ Ljubljana, Društvo slovenskih skladateljev; Köln, Musikverlage Hans Gerig, 1975. Partitura, 90 str., $49 \mathrm{~cm}$. (Edicije Društva slovenskih skladateljev, 478). HG 793. Prevzeto v založbo Breitkopf und Härtel, Wiesbaden.

Simfonija Pietà. Orkester. Ljubljana, 9.2.1995. Partitura, rkp., svinčnik, 41 str., 43 cm; čtp., črnilo, 56 str., $42 \mathrm{~cm}$. Naslov na čistopisu: Simfonija Pieta za orkester. Čistopis se nahaja v Društvu slovenskih skladateljev.

Simfonija I. [prva]. Orkester. Ljubljana, 26.3.1940 (I. stavek), 1.8.1940 (II. stavek), Bled, 26.9.1940 (III. stavek), 9.1.1941 (IV. stavek). Particella, rkp., svinčnik, 46 str., 35 cm (str. 1-6, 27-28, 41-46), 31 cm (str. 722, 25-26), 23 x 24 cm (str. 23-24), 34 cm (str. 29-32, 39-40), 16 x 24 cm (str. 33-38); partitura, čtp., črnilo, 180 str., 34 cm; partitura (vezan skladateljev prepis, 10.4.1941), čtp., črnilo, 192 str., $35 \mathrm{~cm}$. Naslov na prvem čistopisu: Simfonija. Naslov na platnicah drugega čistopisa: 1. simfonija. Drugi čistopis se nahaja v Društvu slovenskih skladateljev.

Simfonija za godalni orkester, op. 17 [b]. Ljubljana, 1937. Partitura, čtp., črnilo, 17 str., $34 \mathrm{~cm}+5$ partov, čistopis, črnilo, 6, 5, 5, 6, 4 str., $34 \mathrm{~cm}$. Na naslovni strani čistopisa je dopisano s svinčnikom: Pièce symphonique. Naslov na partih viole, violončela in kontrabasa: Pièce symphonique. Verjetno isto kot Quatre pièces symphoniques za godalni orkester, op. 17b. Gl. B. Loparnik, Biti skladatelj, pogovori s Primožem Ramovšem; Ljubljana, Slovenska matica, 1984; str. 254.

Simpozij za tolkala (5 izvajalcev). Ljubljana, 19.12.1974. Partitura, rkp., svinčnik, 9 str., 43 cm; čtp., črnilo?, 20 str., $35 \mathrm{~cm}$. Čistopis je popisan po kseroksni kopiji v arhivu Slovenske filharmonije.

Sinfonietta

gl. Simfonietta 


\section{MUZIKOLOŠKI ZBORNIK • MUSICOLOGICAL ANNUAL XXXV}

Sintaksa. Violončelo, klavir. Ljubljana, 29.9.1987. Partitura, rkp., svinčnik, 4 str., $43 \mathrm{~cm}$.

Natis: $\quad$ Sintaksa za violončelo in klavir. Ljubljana, Društvo slovenskih skladateljev, 1992. Partitura, 11 str., $34 \mathrm{~cm}$. (Edicije Društva slovenskih skladateljev, 1315). Reprodukcija skladateljevega rokopisa.

Sinteze za rog in 3 orkestrske grupe. Ljubljana, 14.8.1971. Partitura, rkp., svinčnik, 27 str., 43 cm; čtp., črnilo, 88 str., $43 \mathrm{~cm}$. Čistopis se nahaja v Društvu slovenskih skladateljev.

Skice za violo in klavir. Ljubljana, 17.7.1958. Partitura, rkp., svinčnik, 6 str., 31 cm; čtp., črnilo, 21 str., 30 $\mathrm{cm}+1$ part ( 5 str.), $30 \mathrm{~cm}$. Na partu so redakcijske oznake Srečka Zalokarja.

Natis: $\quad$ Ljubljana, [samozaložba], 1963. Partitura, 14 str., $31 \mathrm{~cm}+1$ part, 7 str., $30 \mathrm{~cm}$. Na naslovnici parta: Redakcija Srečko Zalokar. Sprejeto v Edicije Društva slovenskih skladateljev, ed. št. 284.

SKT. Kvintet trobil. Ljubljana, 16.9.1988. Partitura, rkp., svinčnik, 6 str., 43 cm; čtp., flomaster, 22 str., 36 cm. Naslov na čistopisu: SKT za kvintet trobil.

Slovenski filharmoniji. Orkester. Ljubljana, 30.4.1988. Partitura, rkp., svinčnik, 48 str., 43 cm; čtp., črnilo, 70 str., $43 \mathrm{~cm}$. Posvetilo na čistopisu: Ko ste me ob Vašem letošnjem jubileju imenovali za častnega člana, sem Vam v svoji prvi zahvali za to izjemno priznanje sporočil, da bo moja popolna zahvala šele $\mathrm{v}$ tem, da bom skomponiral simfonično skladbo "Slovenski filharmoniji" in Vam je posvetil. Zdaj to obljubo izpolnjujem in Vam poklanjam skladbo v originalnem rokopisu. Z vsemi najboljšimi željami za Vaše nadaljnje uspešno delo in za plodno sodelovanje s slovenskimi skladatelji, Vaš Primož Ramovš. Ljubljana, 1.9.1988. Čistopis se nahaja v arhivu Slovenske filharmonije.

Solo da trombone. Ljubljana, 5.3.1984. Rkp., svinčnik, 2 str., 43 cm; čtp., flomaster, 5 str., 36 cm. Naslov na čistopisu: Solo da trombone za altovsko pozavno.

Solo za kontrabas. Ljubljana, 10.10.1972. Rkp., svinčnik, 4 str., $43 \mathrm{~cm}$.

Sol(tanto). Flavta, klavir. Ljubljana, 5.5.1993. Partitura, rkp., svinčnik, 7 str., 43 cm; čtp., flomaster, 19 str., $35 \mathrm{~cm}+$ razlaga znakov, [1] str., $30 \mathrm{~cm}$. Naslov na čistopisu: Sol(tanto) per flauto e pianoforte. Posvetilo: À Luisa Sello! Posvetilo na čistopisu: Un sincero omaggio alla Maestra Luisa Sello.

Sonata breve za violino in klavir. Ljubljana, 21.3.1956. Partitura, rkp., svinčnik, 19 str., $31 \mathrm{~cm}$.

Natis: $\quad$ Sonata za violino in klavir. Ljubljana, Društvo slovenskih skladateljev, 1957. Partitura, 38 str., $33 \mathrm{~cm}+1$ part, $12 \mathrm{str}$., $32 \mathrm{~cm}$. (Edicije Društva slovenskih skladateljev, 26). Naslov na partu: Sonata breve.

Sonata quasi una phantasia, [op. 25]. Klavir. Ljubljana, 13.9.1937. Čtp., črnilo, 4 str., 34 cm.

Sonata za klarinet in klavir. Ljubljana, 3.12.1953. Partitura, rkp., svinčnik, 14 str., 31 cm; čtp. (krtačni odtis), 33 str., $30 \mathrm{~cm}$.

Natis: Ljubljana, [samozaložba], 1958. Partitura, 33 str., $30 \mathrm{~cm}+1$ part, $11 \mathrm{str}$., $30 \mathrm{~cm}$. Sprejeto v Edicije Društva slovenskih skladateljev, ed. št. 244.

Sonata za klavir štiriročno. Rateče, 13.5.1987. Partitura, rkp., svinčnik, 7 str., 43 cm; čtp., flomaster, 19 str., $35 \mathrm{~cm}$. Posvetilo: Alenki in Igorju!

Sonata za violino in klavir

gl. Sonata breve za violino in klavir

Sonatina. Godalni orkester. Wolfgang Amadeus Mozart. [Ljubljana], 1955. Pogrešano. Popisano po skladateljevem seznamu del.

Sonatina. Klavir. [Ljubljana], 19.10.1953. Rkp., svinčnik, str. 4-7, $31 \mathrm{~cm}$. Priključeno k: Tema z variacijami.

Natis: $\quad$ Sonatina za klavir. Ljubljana, samozaložba, 1954. 10 str., 29 cm. Sprejeto v Edicije Društva slovenskih skladateljev, ed. št. 232.

Sonatina za godala

gl. Sedem skladb za godalni orkester

Sonatina za harfo. Ljubljana, 6.7.1955. Rkp., svinčnik, 9 str., $31 \mathrm{~cm}$.

Sonatina za klarinet in klavir. Ljubljana, 12.8.1959. Partitura, rkp., svinčnik, 8 str., $31 \mathrm{~cm}$.

Natisa: $\quad$ Ljubljana, Društvo slovenskih skladateljev, 1960. Partitura, 15 str., $32 \mathrm{~cm}+1$ part, 4 str., $32 \mathrm{~cm}$. (Edicije Društva slovenskih skladateljev, 85). Naslov na partu: Sonatina. 


\section{MUZIKOLOŠKI ZBORNIK • MUSICOLOGICAL ANNUAL XXXV}

[Ponatis.] Ljubljana, Društvo slovenskih skladateljev; Köln, Musikverlage Hans Gerig, 1977. Partitura, 13 str., $35 \mathrm{~cm}+1$ part, 4 str., $35 \mathrm{~cm}$. (Edicije Društva slovenskih skladateljev, 85). HG 1273. Prevzeto v založbo Breitkopf und Härtel, Wiesbaden.

Sonatina za klarinet, trobento in klavir. Ljubljana, 17.4.1953. Partitura, rkp., svinčnik, 4 str., 31 cm; čtp., flomaster, 11 str., $36 \mathrm{~cm}$.

Sonatina za rog in klavir. Ljubljana, 29.12.1959. Partitura, rkp., svinčnik, 9 str., 31 cm; čtp., črnilo, 27 str., $36 \mathrm{~cm}$.

Natis: $\quad$ Ljubljana, Društvo slovenskih skladateljev, 1962. Partitura, 23 str., $32 \mathrm{~cm}+1$ part, 6 str., $31 \mathrm{~cm}$. (Edicije Društva slovenskih skladateljev, 136).

Soneti nesreče. Recitator, kljunasta flavta. Besedilo France Prešeren. Ljubljana, 11.1.1992. Partitura, rkp., svinčnik, 10 str., $43 \mathrm{~cm}$; čtp., flomaster, 20 str., $43 \mathrm{~cm}$. Naslov na čistopisu: Soneti nesreče za kljunasto flavto in recitatorja.

Natis: Soneti nesreče za kljunasto flavto in recitatorja. [Besedilo France Prešeren]. Ljubljana, Koncertna agencija Klemen Ramovš Management, 1994. Partitura, 20 str., 24 cm. Reprodukcija avtorjevega rokopisa. Karel Brišnik, [Uvodna beseda]. Izdano kot programska knjižica za krstno izvedbo 8.2.1994.

Sounds. Flavta, harfa. Ljubljana, 30.8.1975. Partitura, rkp., svinčnik, 6 str., 43 cm; čtp., flomaster, 19 str., 36 $\mathrm{cm}$. Naslov na čistopisu: Sounds za flavto in harfo. Posvetilo: Tinki in Pavli! Posvetilo na čistopisu: Tinki Muradori in Pavli Uršič!

Sporočilo za violino solo. Rateče, 16.10.1976. Rkp., svinčnik, 3 str., 43 cm; čtp., flomaster, 7 str., $36 \mathrm{~cm}$. Posvetilo: Josipu Klimi!

Srečanje za harmonikarski orkester. Rateče, 18.6.1984. Partitura, rkp., svinčnik, 5 str., 43 cm; čtp., flomaster, 10 str., $42 \mathrm{~cm}$.

Natis: $\quad$ Srečanje za harmonikaški orkester. - v: Akkorden. Br. 1, sv. 5. Novi Sad, Savez muzičkih društava Vojvodine, 1988. Partitura, 10 str., $30 \mathrm{~cm}$. (Jugoslovenska edicija orkestri harmonika). Popisano po zapisu iz vzajemne baze COBIB.

STA - SPAR - ECK. Trio (flavta, basovski klarinet, klavir). Ljubljana, 27.7.1989. Partitura, rkp., svinčnik, 9 str., $43 \mathrm{~cm}$; čtp., flomaster, 28 str., $35 \mathrm{~cm}$. Naslov na čistopisu: STA - SPAR - ECK (per flauto, clarinetto basso, pianoforte). Posvetilo: À Het Trio!

Stavek za godalni kvartet. [Ljubljana], 1942. Pogrešano. Popisano po skladateljevem seznamu del.

Sto let za kljunasto flavto. Ljubljana, 20.6.1990. Rkp., svinčnik, 2 str., $43 \mathrm{~cm}$; čtp., flomaster, 6 str., $35 \mathrm{~cm}$.

Sto taktov. Godalni kvartet. Ljubljana, 6.4.1981. Partitura, rkp., svinčnik, 4 str., 43 cm; čtp., flomaster, 13 str., $36 \mathrm{~cm}$. Posvetilo: Zagrebškemu godalnemu kvartetu! Naslov na čistopisu: Sto taktov za godalni kvartet.

Studio. Kvartet (basovska kljunasta flavta, violina, violončelo, klavir). Ljubljana, 25.5.1982. Partitura, rkp., svinčnik, 6 str., 43 cm; čtp., flomaster, 12 str., 43 cm. Posvetilo Klemenu! Naslov na čistopisu: Studio za basovsko kljunasto flavto, violino, violončelo in klavir.

Suita za dva klavirja. [Ljubljana], 1961. Pogrešano. Popisano po skladateljevem seznamu del.

Suita za 2 violini, violončelo in godalni orkester. Ljubljana, 2.5.1950. Particella, rkp., svinčnik, 17 str., 31 cm; partitura, čtp., flomaster, 39 str., 42 cm; partitura, čtp., 58 str., 32 cm. Stavki: Ouverture, Menuet, Gavotte, Corale + Siciliana (v drugem čistopisu: Sicilienne), Gigue. Prvi čistopis se nahaja v Društvu slovenskih skladateljev, drugi čistopis je v arhivu Slovenske filharmonije.

Delna priredba: Suita za klavir štiriročno. Ljubljana, 17.11.1950. Partitura, rkp., svinčnik, 8 str., $31 \mathrm{~cm}$. Stavki: Menuet, Koral - Siciliana, Gavotta.

Suita za klavir. [Ljubljana, 1936 ali 1937]. Rkp., črnilo, str. 4-6, 35 cm. Priključeno k: Vprašanje.

Suita za klavir. Roma, 6.4.1942. Rkp., svinčnik, 13 str., 34 cm (str. 1-12), 20 x 28 cm (str. 13.).

Natis: $\quad$ Ljubljana, Akademska založba, 1943. 25 str., 34 cm. Posvetilo: Spominu Slavka Osterca.

Suita za klavir štiriročno

gl. Suita za 2 violini, violončelo in godalni orkester 


\section{MUZIKOLOŠKI ZBORNIK • MUSICOLOGICAL ANNUAL XXXV}

Sv. Benedikt [I]. Mešani zbor. Besedilo Roman Tominec. Ljubljana, 1.3.1954. Partitura, rkp., svinčnik, str. [1], $25 \mathrm{~cm}$. Priključeno: Sv. Benedikt [II].

Natis: 1. Sv. Benedikt. V Ljubljani, [samozaložba], 1954. Partitura, str. [1], $30 \mathrm{~cm}$. Priključeno: 2. Sv. Benedikt.

Sv. Benedikt [II]. Mešani zbor. [Besedilo Roman Tominec]. Ljubljana, 2.3.1954. Partitura, rkp., svinčnik, str. [2], $25 \mathrm{~cm}$. Priključeno k: Sv. Benedikt [I].

Natis: $\quad$ 2. Sv. Benedikt. V Ljubljani, [samozaložba], 1954. Partitura, str. [2], $30 \mathrm{~cm}$. Priključeno k: 1 . Sv. Benedikt.

Svobodni dialog. Orkester. Ljubljana, 24.9.1987. Partitura, rkp., svinčnik, 46 str., 43 cm + zapis koralne melodije, kemični svinčnik, $8 \times 11 \mathrm{~cm}$; čtp., črnilo, 63 str., $43 \mathrm{~cm}$. Naslov na čistopisu: Svobodni dialog za simfonični orkester. Čistopis se nahaja v Društvu slovenskih skladateljev.

Syrigma. Kljunasta flavta. Ljubljana, 8.2.1984. Rkp., svinčnik, 2 str., $43 \mathrm{~cm}$; čtp., flomaster, $6 \mathrm{str}$., $36 \mathrm{~cm}$. Naslov na čistopisu: Syrigma za kljunasto flavto. Posvetilo: Klemenu!

Natis: $\quad$ Syrigma za kljunasto flavto. Ljubljana, Inferno, cop. $1990.3 \mathrm{str} ., 31 \mathrm{~cm}$. (Edition Ramovš). Inferno ER 1001.

Šest etud. Kljunasta flavta. Ljubljana, 30.3.1989. Rkp., svinčnik, 6 str., 43 cm; čtp., flomaster, 15 str., $35 \mathrm{~cm}$. Naslov na čistopisu: Šest etud za kljunasto flavto. Posvetilo: Klemenu! Čistopis se nahaja v Društvu slovenskih skladateljev.

Šest malih preludijev za klavir. Ljubljana, 12.4.1949. Rkp., svinčnik, 6 str., 31 cm; čtp., črnilo, 19 str., 32 $\mathrm{cm}$. Vsebina: V oktavah, V kvartah, V kvintah, V sekundah, V skalah, Ostinato.

Natis: Ljubljana, samozaložba, 1954. 16 str., 29 cm. Sprejeto v Edicije Društva slovenskih skladateljev, ed. št. 218.

Šest miniatur. Pihalni trio. Ljubljana, 1.12.1982. Partitura, rkp., svinčnik, 6 str., 43 cm; čtp., flomaster, 14 str., $36 \mathrm{~cm}$. Naslov na čistopisu: Šest miniatur za pihalni trio. Posvetilo: Zagrebškemu puhačkemu triu!

Natis: $\quad$ Šest miniatur za pihalni trio. Ljubljana, Društvo slovenskih skladateljev, 1984. Partitura, 10 str., $35 \mathrm{~cm}$. (Edicije Društva slovenskih skladateljev, 1093).

Štiri invencije. Kvartet trombonov. Ljubljana, 22.2.1984. Partitura, rkp., svinčnik, 4 str., $43 \mathrm{~cm}+$ razlage znakov, svinčnik, [1] str., $22 \mathrm{~cm}$; čtp., flomaster, 12 str., $36 \mathrm{~cm}+$ razlage znakov, tipkopis, [1] str., $30 \mathrm{~cm}$. Naslov na čistopisu: Štiri invencije za štiri trombone.

Štiri za štiri. Kvartet kljunastih flavt. Ljubljana, 31.1.1987. Partitura, rkp., svinčnik, 3 str., 43 cm; čtp., flomaster, 10 str., $35 \mathrm{~cm}$. Naslov na čistopisu: Štiri za štiri za kvartet kljunastih flavt.

Štirikrat štiri strune. Godalni kvartet. Ljubljana, 9.3.1998. Partitura, rkp., svinčnik, 5 str., 43 cm; čtp., flomaster, 8 str., $43 \mathrm{~cm}$. Naslov na čistopisu: Štirikrat štiri strune za godalni kvartet. Posvetilo: Kvartetu Feguš!

Štiriročno za klavir. Ljubljana, 11.1.1972. Partitura, rkp., svinčnik, 7 str., 34 cm; čtp., flomaster, 21 str., 36 $\mathrm{cm}$. Naslov na čistopisu: Štiriročno. Čistopis je popisan po kseroksni kopiji. Posvetilo na rokopisu: Alenki in Igorju Dekleva! Posvetilo na čistopisu: Alenki in Igorju!

Štirje letni časi

gl. I. [Prva] sonata, op. 7

Štirje utrinki. Violina, harfa. Rateče, 2.10.1985. Partitura, rkp., svinčnik, 4 str., 43 cm; čtp., flomaster, 11 str., $35 \mathrm{~cm}$. Naslov na čistopisu: Štirje utrinki za violino in harfo.

Tako in tako. Kontrabas, klavir. Ljubljana, 4.9.1992. Partitura, rkp., svinčnik, 4 str., 43 cm; čtp., flomaster, 13 str., $36 \mathrm{~cm}$. Naslov na čistopisu: Tako in tako za kontrabas in klavir. Podnaslov na čistopisu: ZaŽIGAlna skladba. Posvetilo na rokopisu: Žigi! Posvetilo na čistopisu: Žigi Golobu!

Tako naj bo. Trio (klarinet, fagot, klavir). Ljubljana, 5.2.1987. Partitura, rkp., svinčnik, 3 str., 43 cm; čtp., flomaster, 10 str., $36 \mathrm{~cm}$. Naslov na čistopisu: Tako naj bo za klarinet, fagot in klavir.

Natis: $\quad$ Tako naj bo za klarinet, fagot in klavir. Ljubljana, Društvo slovenskih skladateljev, 1988. Partitura, 6 str., $35 \mathrm{~cm}$. (Edicije Društva slovenskih skladateljev, 1213). 


\section{MUZIKOLOŠKI ZBORNIK • MUSICOLOGICAL ANNUAL XXXV}

Tebe ljubi moja duša. Ženski zbor, orgle. Brez besedila. [S. l., okrog 1940]. Partitura, čtp., črnilo, [1] str., $35 \mathrm{~cm}+3$ parti, črnilo, à [1] str., 14 x $26 \mathrm{~cm}$ (sopran I), 10 x $26 \mathrm{~cm}$ (sopran II), 11 x $26 \mathrm{~cm}$ (alt).

Tema z variacijami. Klavir. [Ljubljana], 13.10.1953. Rkp., svinčnik, str. 1-2, $31 \mathrm{~cm}$. Priključeno: Carillon; Sonatina; Bagatele za klavir.

Natis: $\quad$ Slovenske klavirske skladbe za mladino. I. album (A). Izbrali in uredili Zorka Bradačeva in Silva Hrašovčeva. 3. pomnožena izdaja. Ljubljana, Državna založba Slovenije, 1956. Str. 34-36.

Tetrafonia. Godalni kvartet. Ljubljana, 17.2.1998. Partitura, rkp., svinčnik, 7 str., 43 cm; čtp., flomaster, 9 str., $43 \mathrm{~cm}$. Naslov na čistopisu: Tetrafonia za godalni kvartet.

Thème donné za pozavno in ansambel. Ljubljana, 29.7.1972. Partitura, rkp., svinčnik, 12 str., 43 cm; čtp., flomaster, 28 str., $43 \mathrm{~cm}$. Posvetilo: Ansamblu "Slavko Osterc" ob njegovi 10-letnici! Čistopis se nahaja v Društvu slovenskih skladateljev.

$T I L-E D$. Rog, violončelo. Ljubljana, 28.5.1985. Partitura, rkp., svinčnik, 3 str., 43 cm; čtp., flomaster, 7 str., $36 \mathrm{~cm}$. Naslov na čistopisu: TIL - ED za rog in violončelo. Posvetilo: Tilnu in Ediju Majaronu!

To je možno. Kljunasta flavta, kontrabasovska tuba. Ljubljana, 9.5.1988. Partitura, rkp., svinčnik, 2 str., 43 cm; čtp., flomaster, 6 str., $35 \mathrm{~cm}$. Naslov na čistopisu: To je možno za kljunasto flavto in kontrabasovsko tubo.

Toccata. Klavir. Recoaro, 3.7.1942. Rkp., svinčnik, 4 str., 33 cm; čtp., črnilo, 4 str., 34 cm. Naslov na čistopisu: Tokata za klavir.

Toccata za klavir. Ljubljana, 2.7.1980. Rkp., svinčnik, 4 str., 43 cm; čtp., flomaster, 11 str., 36 cm. Čistopis je popisan po kseroksni kopiji. Posvetilo: Igorju Deklevi!

Tokata

gl. Sedem skladb za godalni orkester

Tokata. Klavir. Ljubljana, 19.2.1944. Rkp., svinčnik, str. 3-6, 34 cm. Priključeno k: Preludij.

Natis: $\quad$ Preludij, pastoral, tokata za klavir. V Ljubljani, Akademska založba, 1944. Str. 8-16, 31 cm. A.Z. 5.

Tokata. Ksilorimba, vibrafon, klavir. Ljubljana, 29.11.1985. Partitura, rkp., svinčnik, 4 str., 43 cm; čtp., flomaster, $11 \mathrm{str}$., $35 \mathrm{~cm}$. Naslov na čistopisu: Tokata za ksilorimbo, vibrafon in klavir. Posvetilo na rokopisu: Dragemu Urbanu! Posvetilo na čistopisu: Urbanu Golobu!

Tokata za klavir

gl. Toccata

Tokata za orgle. Ljubljana, 17.11.1960. Rkp., svinčnik, 7 str., $31 \mathrm{~cm}$.

Totus tuus. Orgle. Ljubljana, 15.2.1996. Rkp., svinčnik, 4 str., 43 cm; čtp., flomaster, 12 str., 36 cm. Naslov na čistopisu: Totus tuus za orgle. Čistopis je popisan po kseroksni kopiii.

Priredba: Ves Tvoj. Klavir. Ljubljana, 18.4.1996. Rkp., svinčnik, 2 str., 43 cm; čtp., flomaster, 6 str., $35 \mathrm{~cm}$. Naslov na čistopisu: Ves tvoj za klavir.

Transferences za harfo in tolkala. Ljubljana, 9.1.1973. Partitura, rkp., svinčnik, 9 str., 43 cm; čtp., flomaster, 25 str., $36 \mathrm{~cm}$.

Transformacije (na Merkùjevo voščilo) za 2 violi in 10 godal. Ljubljana, 5.8.1963. Particella, rkp., svinčnik, 15 str., $31 \mathrm{~cm}+$ zapis tonske serije, svinčnik, [1] str., $9 \times 14 \mathrm{~cm}$.

III. [Tretja] simfonija. Orkester. Ljubljana, 23.7.1948. Particella, rkp., svinčnik, 37 str., 31 cm; partitura, čtp., črnilo, 216 str., $31 \mathrm{~cm}$. Čistopis se nahaja v Društvu slovenskih skladateljev.

Tri miniature za violino in klavir

gl. Miniature za klavir

Tri misli. Harfa. Ljubljana, 1.8.1991. Rkp., svinčnik, 3 str., 43 cm; čtp., flomaster, 11 str., 35 cm. Naslov na čistopisu: Tri misli za harfo. Posvetilo: Mojci Zlobko!

3: 2 [ Tri proti dva] za tolkala. Ljubljana, 30.7.1964. Partitura, rkp., svinčnik, 2 str., $31 \mathrm{~cm}$. 


\section{MUZIKOLOŠKI ZBORNIK • MUSICOLOGICAL ANNUAL XXXV}

Tri skladbe. Klavir. Ljubljana, 29.11.1945. Rkp., svinčnik, 7 str., 31 cm; čtp., črnilo, 20 str., 34 cm. Stavki: Allegro molto, Largo non troppo, Presto.

Delni natis: Largo (Largo non troppo). - v: Slovenske klavirske skladbe za mladino. VI. album. Izbrali in uredili Zorka Bradačeva in Silva Hrašovčeva. Ljubljana, Državna založba Slovenije, 1949. Str. 30-31.

Tri skladbice za Polonco za klavir. Ljubljana, 22.2.1966. Rkp., svinčnik, 2 str., 24 x 30 cm. Vsebina: Budilka, Mali ples, Uspavanka.

Tri srca. Trio (violina, rog, klavir). Ljubljana, 5.4.1984. Partitura, rkp., svinčnik, 7 str., 43 cm; čtp., flomaster, 26 str., $36 \mathrm{~cm}$. Naslov na čistopisu: Tri srca za violino, rog in klavir.

Tri za tri. Trio kljunastih flavt. Ljubljana, 2.5.1987. Partitura, rkp., svinčnik, 4 str., 43 cm; Tri za tri za tercet kljunastih flavt. Posvetilo: Klemenu!

\section{Triangulum}

gl. Trikotnik

Trije kolegi. Trio (flavta, violončelo, klavir). Ljubljana, 16.2.1988. Partitura, rkp., svinčnik, 7 str., $43 \mathrm{~cm}$; čtp., flomaster, 21 str., $35 \mathrm{~cm}$. Naslov na čistopisu: Trije kolegi za flavto, violončelo in klavir.

Trije nokturni za flavto in vibrafon. Ljubljana, 5.12.1964. Partitura, rkp., svinčnik, 3 str., $31 \mathrm{~cm}+$ zapis tonske serije, svinčnik, [1] str., $8 \times 24 \mathrm{~cm}$.

Trije nokturni za kontrabas. Ljubljana, 24.4.1972. Rkp., svinčnik, 4 str., 36 cm.

Trije pari. Rog, tuba. Ljubljana, 30.8.1994. Partitura, rkp., svinčnik, 4 str., 43 cm; čtp., flomaster, 8 str., 36 $\mathrm{cm}$. Naslov na čistopisu: Trije pari za rog in tubo.

Trije pastoralčki. Flavta, čembalo. [Ljubljana], 1966. Pogrešano. Popisano po skladateljevem seznamu del.

Trije pastoralčki za altovsko flavto in harfo. Rateče, 19.9.1963. Partitura, rkp., svinčnik, 3 str., $31 \mathrm{~cm}+$ zapis tonske serije, svinčnik, [1] str., $10 \times 24 \mathrm{~cm}$.

Natis: Trije pastoralčki za flavto in harfo. Ljubljana, Društvo slovenskih skladateljev, 1965. Partitura, 6 str., $32 \mathrm{~cm}+1$ part, [3] str., $32 \mathrm{~cm}$. (Edicije Društva slovenskih skladateljev, 277).

3 [Trije] pastorali za oboo d'amore in klavir. Ljubljana, 2.10.1953. Partitura, rkp., svinčnik, 5 str., $31 \mathrm{~cm}$ (str. 1-4), 5 x $24 \mathrm{~cm}$ (str. 5); čtp., flomaster, 10 str., $36 \mathrm{~cm}$. Posvetilo na rokopisu: Reginaldu de Bragu.

Trije preludiji za čembalo. Ljubljana, 14.6.1973. Rkp., svinčnik, 5 str., 43 cm; čtp., flomaster, 13 str., $36 \mathrm{~cm}$. Posvetilo: Oliveri Đorđevićevi!

Trije preludiji za harfo. Ljubljana, 21.4.1959. Rkp., svinčnik, $5 \mathrm{str}, 31 \mathrm{~cm}$.

Trije preludiji za klavir. Ljubljana, 19.12.1972. Rkp., svinčnik, 2 str., 43 cm; čtp., črnilo, 7 str., 36 cm. Čistopis se nahaja v Društvu slovenskih skladateljev.

Trije trenutki za kitaro. Ljubljana, 31.3.1990. Rkp., svinčnik, 2 str., $43 \mathrm{~cm}$; čtp., flomaster, 7 str., $35 \mathrm{~cm}$. Posvetilo na rokopisu: Marinku Opaliću!

(Trikotnik) Triangulum. Marimbafon. Ljubljana, 3.8.1988. Rkp., svinčnik, 2 str., 43 cm; čtp., flomaster, 8 str., $35 \mathrm{~cm}$; čtp., flomaster, $8 \mathrm{str}$., $35 \mathrm{~cm}$. Naslov na prvem čistopisu: Trikotnik za marimbafon. Naslov na drugem čistopisu: Triangulum for marimbaphon, Redaction Nebojša Živković. Posvetilo na rokopisu: Nebojši Živkoviću! Posvetilo na prvem čistopisu: Mojstru Nebojši Živkoviću! Posvetilo na drugem čistopisu: For Nebojša J. Živković!

Trikrat. Violončelo, kitara. Ljubljana, 30.3.1987. Partitura, rkp., svinčnik, 3 str., 43 cm; čtp., flomaster, 9 str., $35 \mathrm{~cm}$. Naslov na čistopisu: Trikrat za violončelo in kitaro.

Trio za 2 oboi (oboo in klarinet) in fagot. Recoaro, 21.9.1942. Particella, rkp., svinčnik, 6 str., 33 cm; partitura, čtp., črnilo, 24 str., $33 \mathrm{~cm}$. Naslov na čistopisu: Pihalni trio.

Natis: $\quad$ Pihalni trio. V Ljubljani, Akademska založba, 1943. Partitura, 19 str., $31 \mathrm{~cm}$. A. Z. 4.

Trio za 2 violini in violo. Ljubljana, 12.6.1954. Partitura, rkp., svinčnik, 9 str., $31 \mathrm{~cm}$.

Trio za flavto, violo in kitaro. Ljubljana, 6.7.1989. Partitura, rkp., svinčnik, 5 str., 43 cm; čtp., flomaster, 10 str., $35 \mathrm{~cm}$. Priredba za flavto, violino in kitaro. Ljubljana, 22.9.1989. Partitura, čtp. (kseroksna kopija z nalepljenimi popravki), flomaster, $10 \mathrm{str}$., $35 \mathrm{~cm}+$ part za violino, rkp., svinčnik, [1] str., $43 \mathrm{~cm}$. 


\section{MUZIKOLOŠKI ZBORNIK • MUSICOLOGICAL ANNUAL XXXV}

Trio za klarinet, violončelo in klavir. Ljubljana, 18.12.1957. Partitura, rkp., svinčnik, 17 str., 31 cm. Posvetilo: Al Trio "Ars nova" in segno di stima e sincere ammirazione.

Trio za pikolo, trobento in kontrafagot. Ljubljana, 29.1.1952. Partitura, rkp., svinčnik, 8 str., $31 \mathrm{~cm}$.

Triplum. Pihala, trobila, tolkala. Rateče, 25.10.1980. Partitura, rkp., svinčnik, 50 str., 43 cm; čtp., črnilo, 71 str., $43 \mathrm{~cm}$. Naslov na čistopisu: Triplum za pihala, trobila in tolkala. Čistopis se nahaja v Društvu slovenskih skladateljev.

Triptychon za godalni kvartet. Ljubljana, 21.11.1969. Partitura, rkp., svinčnik, 14 str., 31 cm; čtp., črnilo, 20 str., 36 cm. Posvetilo: Komponirano po naročilu Društva slovenskih skladateljev, posvečeno Josipu Klimi in Zagrebškemu godalnemu kvartetu! Čistopis se nahaja v Društvu slovenskih skladateljev.

Natis: Ljubljana, Društvo slovenskih skladateljev; [Köln, Musikverlag Hans Gerig], 1972. Partitura, 20 str., $36 \mathrm{~cm}$. (Edicije Društva slovenskih skladateljev, 324). HG 973. Prevzeto v založbo Breitkopf und Härtel, Wiesbaden. Pri dnu prve strani: Ed.DSS 479.

Trobenta, mladinski zbor

gl. Kanoni za 2 ali 3 glasove

Trojica. Klavir. Rateče, 19.9.1974. Rkp., svinčnik, 3 str., 43 cm.

Trojka. Trio (flavta, angleški rog, triangel). Ljubljana, 25.7.1988. Partitura, rkp., svinčnik, 3 str., 43 cm; čtp., flomaster, 7 str., $35 \mathrm{~cm}$. Naslov na čistopisu: Trojka za flavto, angleški rog in triangel. Posvetilo na rokopisu: Milošu, Dini, Ireni!

Trojni koncert. Oboa, klarinet, fagot, orkester. Ljubljana, 22.8.1990. Partitura, rkp., svinčnik, 56 str., 43 cm; čtp., črnilo, 77 str., $42 \mathrm{~cm}$. Naslov na čistopisu: Trojni koncert za oboo, klarinet, fagot in orkester. Posvetilo: Novemu ljubljanskemu pihalnemu triu! Čistopis se nahaja v Društvu slovenskih skladateljev.

Trošt: Stati inu obstati. Preludij [in] postludij. Orgle. Ljubljana, 26.1.1998. Rkp., svinčnik, [1] str., 22 x 30 $\mathrm{cm}$.

Unda maris. Trio (flavta, klarinet, klavir). Ljubljana, 18.8.1997. Partitura, rkp., svinčnik, 6 str., 43 cm; čtp., flomaster, 16 str., $33 \mathrm{~cm}$. Naslov na čistopisu: Unda maris za flavto, klarinet in klavir.

Ura, flavta, zvončki, ksilofon, palice

gl. Mladinske skladbe za Orffov instrumentarij

Uspavanka. [À bocca chiusa]. Mladinski zbor. Ljubljana, 6.2.1973. Partitura, rkp., svinčnik, str. 1, $43 \mathrm{~cm}$. Priključeno: Žabe.

Natis: $\quad$ Grlica 17/1974-75, 1-2, notni del 12-13.

Uspavanka, dve flavti, metalofon

gl. Mladinske skladbe za Orffov instrumentarij

Uspavanka

gl. Bagatele za klavir

Uspavanka

gl. Iz "Cicibana" za mladinski zbor

Uspavanka

gl. Tri skladbice za Polonco za klavir

Uspavanka. Kljunasta flavta, klavir. Ljubljana, 13.12.1971. Partitura, rkp., svinčnik, 2-3 str., 34 cm. Priključeno k: Pastoral za blokflavto in klavir.

Uspavanka, violina, klavir gl. Miniature za klavir

Uspavanka za 2 violini in klavir. Ljubljana, 3.12.1960. Partitura, rkp., svinčnik, 2 str., $31 \mathrm{~cm}$.

Uspavanka za Nevo. Klavir. Ljubljana, 9.5.1990. Rkp., svinčnik, [1] str., 43 cm; čtp., flomaster, [2] str., 36 $\mathrm{cm}$. Čistopis je popisan po kseroksni kopiji. 


\section{MUZIKOLOŠKI ZBORNIK • MUSICOLOGICAL ANNUAL XXXV}

Utrinki ob Bachovem imenu za klavir. [Ljubljana], 30.12.1963 (I.-IV.), 31.12.1963 (V.), 11.6.1964 (VI.), 28.7.1964 (VII.-IX.), 6.10.1964 (X.-XI.), 9.10.1964 (XII.-XIII.), 27.10.1964 (XIV.-XV.). Rkp., svinčnik, 9 str., $31 \mathrm{~cm}$.

Natis: Ljubljana, [samozaložba], $1965.14 \mathrm{str} ., 30 \mathrm{~cm}$.

Uvertura Bizetjeve opere „Carmen za violino, klavir, trobento in tolkala. [Ljubljana, okrog 1933]. Partitura, rkp., svinčnik, 3. zv., str. 102-112, 31 cm. Priključeno k: Čudodelna roka, op. 2.

Uvertura "Cudodelna roka"

gl. Orpheus in Euridika, op. 4

V dvoje. Dve violini. Ljubljana, 20.2.1997. Partitura, rkp., svinčnik, 3 str., 43 cm; čtp., flomaster, 11 str., 36 $\mathrm{cm}$. Naslov na čistopisu: V dvoje za dve violini.

Vkvartah

gl. Šest malih preludijev za klavir

Vkvintah

gl. Šest malih preludijev za klavir

V mesečini. Mešani zbor. Besedilo Anton Podbevšek. Ljubljana, 10.1.1956. Partitura, rkp., svinčnik, [2] str., $31 \mathrm{~cm}$.

Natis: $\quad$ Slovenska pesmarica. Prvi del. Uredila Luka Kramolc in Matija Tomc. Celje, Mohorjeva družba, 1963. Str. 92-94.

Voktavah

gl. Šest malih preludijev za klavir

V sekundah

gl. Šest malih preludijev za klavir

Vskalah

gl. Šest malih preludijev za klavir

$V$ soglasju. Klarinet, harmonika. Ljubljana, 1.7.1996. Partitura, rkp., svinčnik, 4 str., 43 cm; čtp., flomaster, $13 \mathrm{~cm}, 36 \mathrm{~cm}$. Naslov na čistopisu: V soglasju za klarinet in harmoniko.

V soglasju. Trio (orgle, tenorska gamba, basovska gamba). Ljubljana, 13.7.1995. Partitura, rkp., svinčnik, 3 str., $43 \mathrm{~cm}$; čtp., flomaster, 7 str., $33 \mathrm{~cm}$. Naslov na čistopisu: V soglasju za orgle, tenorsko in basovsko gambo. Posvetilo na rokopisu: Pahorjem! Posvetilo na čistopisu: Dragim Pahorjem!

Variacije. Violina, klavir. [Ljubljana, 1950]. Partitura, rkp., svinčnik, 3 str., $31 \mathrm{~cm}$.

Variacije na "An die Freude" iz IX. Beethovenove simphonije, op. 8. Flavta, violina, dva klavirja. Ljubljana, 22.5.1935. Rkp., črnilo, str. 1-15, $31 \mathrm{~cm}$. Priključeno: Koračnica po napevih slovenskih narodnih pesmi, op. 9.

Variacije na pesem "Tito naš tovariš". Kljunasta flavta, klavir. Ljubljana, 29.10.1983. Partitura, rkp., svinčnik, 5 str., $43 \mathrm{~cm}$. Naslov v skladateljevem seznamu del in v B. Loparnik, Biti skladatelj, pogovori s Primožem Ramovšem; Ljubljana, Slovenska matica, 1984; str. 268: Variacije za kljunasto flavto in klavir.

Variacije za klavir. Ljubljana, 13.12.1960. Rkp., svinčnik, 4 str., $31 \mathrm{~cm}$.

Natis: Ljubljana, [samozaložba], 1961.9 str., $30 \mathrm{~cm}$.

Variacije za kljunasto flavto in klavir

gl. Variacije na pesem "Tito naš tovariš", kljunasta flavta, klavir

Vedno znova. Fagot, klavir. Ljubljana, 21.8.1987. Partitura, rkp., svinčnik, 2 str., 43 cm; čtp., flomaster, 8 str., $35 \mathrm{~cm}$. Naslov na čistopisu: Vedno znova za fagot in klavir.

Veni Sancte Spiritus. Ženski zbor, dve violi, violončelo. Ljubljana, 11.6.1946. Partitura, rkp., svinčnik, 4 str., $31 \mathrm{~cm}$; čtp., črnilo, 7 str., $31 \mathrm{~cm}$. Naslov na čistopisu: Veni Sancte Spiritus za sopran, alt, 2 violi in violoncello.

Natis: $\quad$ Cerkveni glasbenik 78/1985, 7-9, notna priloga 17-24.

Venturini: Jagnje božje. Mešani zbor. [Ljubljana], ?. Partitura, rkp., svinčnik, [1] str., 22 x 30 cm. 


\section{MUZIKOLOŠKI ZBORNIK • MUSICOLOGICAL ANNUAL XXXV}

Ves Tvoj, klavir

gl. Totus tuus, orgle

Violoncello solo. Ljubljana, 23.8.1979. Rkp., svinčnik, 2 str., 43 cm; čtp., flomaster, 6 str., 36 cm.

Viribus unitis. Trio (violina, kitara, harmonika). Ljubljana, 18.4.1986. Partitura, rkp., svinčnik, 6 str., 43 cm; čtp., flomaster, 18 str., $35 \mathrm{~cm}$. Naslov na čistopisu: Viribus unitis za violino, kitaro in harmoniko.

Vis vim vi superat. Klavir, tolkala. Ljubljana, 21.8.1996. Partitura, rkp., svinčnik, 8 str., 43 cm; čtp., flomaster, $24 \mathrm{str}$, $36 \mathrm{~cm}$. Naslov na čistopisu: Vis vim vi superat za klavir in tolkala.

Viva memoria. Violončelo, klavir. Ljubljana, 7.7.1998. Partitura, rkp., svinčnik, 4 str., 43 cm; čtp., flomaster, 10 str., $36 \mathrm{~cm}$. Naslov na čistopisu: Viva memoria per violoncello e pianoforte.

Vivat, crescat, floreat. Klavir. Ljubljana, 17.8.1995. Rkp., svinčnik, 2 str., 43 cm; čtp., flomaster, 8 str., 35 $\mathrm{cm}$. Naslov na čistopisu: Vivat, crescat, floreat za klavir. Posvetilo: Juretu Rozmanu!

Vprašanje. Glas, klavir. Besedilo Simon Jenko. [Ljubljana, 1936 ali 1937]. Partitura, rkp., črnilo, str. 1-2, 35 cm. Priključeno: Pod gradom; Suita za klavir.

[Vse najboljše, dragi Eto]. Allegro moderato. Triglasni moški zbor. Ljubljana, 30.12.1948. Rkp., svinčnik, str. 16, $31 \mathrm{~cm}$. Priključeno k: Concertino per pianoforte ed orchestra d'archi.

Vzporedja za klavir in godalni orkester. Ljubljana, 12.12.1964. Partitura, rkp., svinčnik, 45 str., $31 \mathrm{~cm}+$ zapis tonske serije, svinčnik, [1] str., $18 \times 24 \mathrm{~cm}+$ navodila v slovenščini, tipkopis, [1] str., $22 \mathrm{~cm}+$ navodila v angleščini, tipkopis, [1] str., $30 \mathrm{~cm}$; čtp., črnilo, 63 str., $31 \mathrm{~cm}+5$ partov, čtp. (matrica), flomaster, à 10 str. (violina I), 8 str. (violina II, viola, kontrabas), 9 str. (violončelo). Čistopis partiture se nahaja v Društvu slovenskih skladateljev.

XY. Klavir. [Ljubljana], 1996. Pogrešano. Popisano po skladateljevem seznamu del.

Za harmoniko. Rateče, 21.9.1983. Rkp., svinčnik, 3 str., 43 cm; čtp., flomaster, 8 str., 36 cm.

Zadostno

gl. Ocene za klavir

Zahvala za kljunasto flavto. Ljubljana, 27.11.1989. Rkp., svinčnik, 2 str., 43 cm; čtp., flomaster, 4 str., 36 $\mathrm{cm}$. Čistopis je popisan po kseroksni kopiji. Posvetilo: Klemenu za 50 izvedb Syrigme.

Natis: $\quad$ Ljubljana, Inferno, cop. 1990. 3 str., 31 cm. (Edition Ramovš). Inferno, ER 1011.

Zakaj pa ne. Harmonikarski orkester. Ljubljana, 4.3.1986. Partitura, rkp., svinčnik, 15 str., 43 cm; čtp., flomaster, 20 str., $42 \mathrm{~cm}$. Naslov na čistopisu: Zakaj pa ne za harmonikarski orkester.

Natis: Zakaj pa ne za harmonikaški orkester. - v: Akkorden. Br. 1, sv. 4. Novi Sad, Savez muzičkih društava Vojvodine, 1988. Partitura, 20 str., $30 \mathrm{~cm}$. (Jugoslovenska edicija orkestri harmonika). Popisano po zapisu iz vzajemne baze COBIB.

Zares in za šalo. Klavir. Ljubljana, 11.7.1995. Rkp. svinčnik, 2 str., 43 cm; čtp., flomaster, 7 str., 35 cm. Naslov na čistopisu: Zares in za šalo za klavir. Rokopis je popisan po kseroksni kopiji.

ZaŽIGAlna skladba

gl. Tako in tako

Zemljo draga, obalo naša...

gl. Himna brigade

Zidari. Enoglasno. Besedilo?. [Ljubljana, 1947]. Rkp., svinčnik, str. [2], 36 cm. Priključeno k: Na Balkanu.

ZOMI. Fagot, klavir. Ljubljana, 16.10.1992. Partitura, rkp., svinčnik, 4 str., 43 cm; čtp., flomaster, 12 str., 36 $\mathrm{cm}$. Naslov na čistopisu: ZOMI za fagot in klavir. Posvetilo na rokopisu: À Zoran Mitev! Posvetilo na čistopisu: Mojstru Zoranu Mitevu!

Zvočna slika za rog in klavir. [Ljubljana], 7.4.1962. Partitura, rkp., svinčnik, 4 str., $31 \mathrm{~cm}+$ zapis tonske serije, svinčnik, [1] str., $10 \times 23 \mathrm{~cm}$.

Natis: Ljubljana, [samozaložba], 1962. Partitura, 8 str., $30 \mathrm{~cm}+1$ part, 2 str., $30 \mathrm{~cm}$.

Zvočni svet dveh klavirjev in orkestra. Ljubljana, 10.12.1993. Partitura, rkp., svinčnik, 59 str., 43 cm; čtp., črnilo, 70 str., 42 cm. Posvetilo: À Duo Dekleva! Čistopis se nahaja v Društvu slovenskih skladateljev. 


\section{MUZIKOLOŠKI ZBORNIK • MUSICOLOGICAL ANNUAL XXXV}

Zvonovi zvonijo. Ženski zbor. Ljubljana, 18.4.1959. Partitura, rkp., svinčnik, str. [1], $31 \mathrm{~cm}$. Priključeno: Kanizij, kanizij; NN.

Žabe. Mladinski zbor. Onomatopoetično besedilo. Ljubljana, 6.2.1973. Partitura, rkp., svinčnik, str. 2, 43 $\mathrm{cm}$. Priključeno k: Uspavanka.

Natis: $\quad G r l i c a$ 15/1972-73, 3-4, 26-28.

Žalna koračnica, duo flavt, pavke, boben

gl. Mladinske skladbe za Orffov instrumentarij

Živio SGŠ! Trobenta, orkester. Ljubljana, 21.7.1994. Partitura, rkp., svinčnik, 19 str., 43 cm; čtp., flomaster, 50 str., $43 \mathrm{~cm}$. Naslov na čistopisu: Živio SGŠ! za trobento in orkester. 


\section{KRONOLOŠKI SEZNAM DEL}

30. november

26. junij

?

15. februar

10. marec

?

?

23. marec

23. marec

22. maj

?

22. maj

?

22. december

22. december

?

15. januar

22. januar

?

?

?

?

7. junij

?

?

?

2. julij

13. september

25. december

?

?

5. junij
1932

Kako je pridna Micka prišla v nebesa, op. 1 (opera)

1933

Cudodelna roka, op. 2 (opera)

Uvertura Bizetjeve opere "Carmen" za violino, klavir, trobento in tolkala

1934

Potpourri slovenskih narodnih pesmi, op. 5(dve violini, klavir štiriročno)

Paževa usoda, op. 3 (opera)

Orpheus in Euridika, op. 4 (opera)

Potpourri Bizet-jeve opere "Carmen" (violina, dva klavirja, tolkala)

\section{5}

Marcia funebre, op. 6 (klavir)

I. sonata, op. 7(klavir; nedokončano)

Variacije na "An die Freude" iz IX. Beethounove simphonije, op. 8 (flavta, violina, dva klavirja)

Missa in Mi-mag[g]iore (E-dur), op. 9 (mešani zbor, orgle; nedokončano)

Koračnica po napevih slovenskih narodnih pesmi, op. 9 (klavir)

Koral za citre $v$ c-molu, op. $10 a$ (pogrešano)

Čudodelna roka, op. $10 b$ (uvertura; orkester)

Fuga in Re-maggiore, op. 12, no. 1 (violina, violončelo)

Fuga in Re-maggiore, op. 12, no. 2 (godalni trio)

\section{6}

Ples podzemskih duhov, op. 11 (mali orkester)

Fuga in Do-maggiore, op. 12, no. 3 (flavta, fagot)

Fuga in Do-maggiore, op. 13, no. 1 (godalni trio)

Fuga in Do-maggiore, op. 13, no. 2 (pogrešano)

Fuga in Sol-maggiore con preludio, op. 13, no. 3 (pogrešano)

Koncert za klavir in veliki orkester, op. 14

Mouvements symphoniques no. 1 et 2, op. 15 (orkester)

Mouvement musical con fuga, op. 16 (komorni ansambel)

1937

Godalni trio, op. 17 [a]

Simfonija za godalni orkester, op. 17[b]

Mouvement sonatique, op. 18 (klavir)

Nevihta, op. 19 (orkester)

Mouvement symphonique no. 3, op. 20 (orkester)

Pihalni kvintet, op. 21.

Noč prihaja, op. 22 (glas, klavir)

Simfonia orientale, op. 23 (orkester)

Petite phantasie, op. 24 (klavir)

Sonata quasi una phantasia, [op. 25] (klavir)

Momenti riflessivi, op. 27(orkester)

Vprašanje (glas, klavir; skladba je morda nastala že leta 1936)

Pod gradom (glas, klavir; skladba je morda nastala že leta 1936)

Suita za klavir (skladba je morda nastala že leta 1936)

1938

Balada za violino, rog in klavir, op. 29 


\section{MUZIKOLOŠKI ZBORNIK • MUSICOLOGICAL ANNUAL XXXV}

9. avgust

?

\section{2. januar \\ 12. april \\ ? september}

\section{4. januar \\ 12. september \\ 23. oktober \\ ? \\ ?}

9. januar

30. avgust

7. november

12. november

?

\section{7. januar}

6. april

5. maj

21. maj

3. julij

21. september

\section{5. januar \\ 21. januar \\ 7. $\mathrm{maj}$}

27. januar

19. februar

21. februar

1. marec

3. julij

17. oktober

7. november

21. november

22. november

21./22. november

? november
Fuga, [op. 26] (orkester)

La mort du loup, op. 28 (orkester; nedokončano)

Fantazija za klavir (pogrešano)

$$
1939
$$

Godalni kvartet

Dies irae (kantata; mešani zbor, orkester)

Kvartet za rogove

$$
1940
$$

Gugalni stol za violino in klavir

Fantasia per pianoforte

Andante za violo in klavir

[Largo] (godalni kvartet; skladba je nastala okrog 1940)

Tebe ljubi moja duša (ženski zbor, orgle; skladba je nastala okrog 1940)

\section{1}

Simfonija I. (orkester)

Divertimento per 2 cornetti, timpani ed archi

Musica funebre (orkester)

Kolo (klavirski trio)

Andante za violo in mali orkester (pogrešano; gl. Andante za violo in klavir)

Ravel: Bolero (priredba za komorni ansambel)

$$
1942
$$

II. godalni kvartet

Suita za klavir

Miniature za solo violino

Scherzo za klavir

Toccata (klavir)

Trio za 2 oboi (oboo in klarinet) in fagot

Rondino za klavir (pogrešano)

Stavek za godalni kvartet (pogrešano)

\section{3}

Ricercare per pianoforte

Divertimento za 2 oboi, fagot in godalni orkester

Ot'če naš' (moški zbor)

\section{4}

Simfonija II. (orkester)

Tokata (klavir)

Preludij(klavir)

Pastorale (klavir)

Divertimento št. 3 za godalni orkester

Mladinske pesmi (pogrešano)

Mali Jožek (otroški zbor; pogrešano)

\section{5}

Bagatela (flavta, dve violi)

Miniature za klavir

Loquebar za ženski zbor

Beati immaculati za deški zbor

2 moteti in honorem S. Caeciliae (ženski zbor)

[Adagio, non troppo] (klavir) 


\section{MUZIKOLOŠKI ZBORNIK • MUSICOLOGICAL ANNUAL XXXV}

29. november

15. januar

11. junij

9. september

12. november

23. julij

28. oktober

20. december

30. december

12. april

12. november

30. december

2. maj

9. avgust

?

22. september

17. november

29. januar

30. april

22. junij

12. november

29. januar

5. februar

17. november

20. februar

17. april

15. september

2. oktober

13. oktober

14. oktober

19. oktober

3. december

1. marec
Tri skladbe (klavir)

\section{6}

Mala suita za klavir

Veni Sancte Spiritus (ženski zbor, dve violi, violončelo)

Koncert za klavir in orkester

Beati immaculati (Ženski zbor, orgle)

\section{7}

Himna brigade (množična pesem; dvoglasni zbor; pogrešano)

$\mathrm{Na}$ Balkanu (množična pesem; dvoglasno)

Na sve načine (množična pesem; enoglasno)

Zidari (množična pesem; enoglasno)

$$
1948
$$

III. simfonija (orkester)

Concertino per pianoforte ed orchestra d'archi

Psalm 50 za ženski zbor in orgle

[Vse najboljše, dragi Eto] (triglasni moški zbor)

1949

Šst malih preludijev za klavir

Iz Miniatur za klavir (violina, klavir; gl. Miniature za klavir)

Koncert za dva klavirja in godalni orkester

$$
1950
$$

Suita za 2 violini, violončelo in godalni orkester

Rondo za 2 klavirja in godalni orkester

Variacije (violina, klavir)

Scherzo za klavir in godalni orkester

Suita za klavir štiriročno (gl. Suita za 2 violini, violončelo in godalni orkester)

\section{1}

Preludij in fuga za orgle

Sarkazmi za klavir

Diptychon orationis (mešani zbor)

Simfonietta (orkester)

\section{2}

Trio za pikolo, trobento in kontrafagot

Preludij in fuga za tolkala

Cantabo Domino (glas, orgle)

\section{3}

Requiem za deški glas, moški zbor in 11 instrumentov

Sonatina za klarinet, trobento in klavir

Ewig Treu (glas, klavir)

3 pastorali za oboo d'amore in klavir

Tema $z$ variacijami za klavir

Carillon (klavir štiriročno)

Sonatina (klavir)

Sonata za klarinet in klavir

1954

Sv. Benedikt [I] (mešani zbor) 
2. marec

12. junij

8. julij

16. november

18. marec

13. april

27. april

30. april

28. maj

6. julij

28. december

?

?
13. april
23. julij
19. november
18. december ?
25. april
17. julij
5. november
13. december ?
18. april
18. april
21. april
22. maj
12. avgust
13. oktober
13. november
11. december
29. december
1. april
4. junij
13. julij
17. november
3. december
13. december

Sv. Benedikt [II] (mešani zbor)

Trio za 2 violini in violo

Bagatele za violo

II. suita za klavir

\section{5}

Musiques funèbres (orkester)

Plautus: Dvojčka (scenska glasba; komorni orkester)

Deus Israël conjungat vos (motet za bariton in orgle)

Fanfara za orgle

Gregorjev binkoštni preludij (violina, klavir)

Sonatina za harfo

Koral in tokata (orkester)

Preludij za violino in klavir

Sonatina (godalni orkester; pogrešano)

$$
1956
$$

$V$ mesečini (mešani zbor)

Iz "Cicibana" za mladinski zbor

Sonata breve za violino in klavir

Bagatele za klavir

Kanizij, Kanizij(ženski zbor)

\section{7}

Ricercare na Merkùjevo temo za oboo in klavir

Mala suita za klavir in godalni orkester

Mrtvaški ples (filmska glasba; orkester)

Trio za klarinet, violončelo in klavir

Kadenca $k$ Tartinijevemu violinskemu koncertu v D-duru

\section{8}

Dve uspavanki za flavto in klavir

Skice za violo in klavir

Adagio za violončelo in godalni orkester

Concerto piccolo za fagot in godalni orkester

$N N$ (klavir)

\section{9}

Pihalni kvintet

Zvonovi zvonijo (ženski zbor)

Trije preludiji za harfo

Intermezzo za violino in harfo

Sonatina za klarinet in klavir

Nokturno za violo in klavir

Rondo za godalni orkester

Shakespeare: Sen kresne noči (scenska glasba; recitator, klavir)

Sonatina za rog in klavir

$$
1960
$$

Burleska za fagot in klavir

Sedem skladb za godalni orkester

Concertino za trobento in orkester

Tokata za orgle

Uspavanka za 2 violini in klavir

Variacije za klavir 


\section{MUZIKOLOŠKI ZBORNIK • MUSICOLOGICAL ANNUAL XXXV}

1961

11. februar

29. marec

14. julij

24. julij

?

16. november ?
24. februar
7. april
15. junij
1. avgust
11. avgust
30. oktober

18. januar

25. januar

15. februar

5. avgust

10. avgust

18. september

19. september

23. november

7. december
5. junij
17. julij
30. julij
14. avgust
27. oktober
5. december
12. december

23. april

10. maj

3. avgust

16. oktober

3. februar

22. februar

26. februar

19. april

17. junij

31. julij

25. avgust

13. december
Pet miniatur za flavto in klarinet

Aforizmi za violo in klavir

Koncert za violino in violo (z orkestrom)

Kontrasti za klavirski trio

Konkretna študija št. 1 za magnetofonski trak

Konkretna študija št. 2 za magnetofonski trak

Koncertantna glasba za pavke in orkester

Suita za dva klavirja

1962

Dialogi za dva klavirja

Zvočna slika za rog in klavir

Sonatina za godala (gl. Sedem skladb za godalni orkester)

Mladinske skladbe za Orffov instrumentarij

Intrada (orkester)

Monolog za violončelo solo

\section{3}

Áphixis (Andreiou) (trombon, tuba)

Enneafonia (komorni ansambel)

Pentektasis za klavir

Transformacije (na Merkùjevo voščilo) za 2 violi in 10 godal

Ekspanzija za altousko flavto

P. Martinu 50 not za 50 let (orgle)

Trije pastoralckki za altovsko flavto in harfo

Apel za rog in komorni ansambel

Dve koralni predigri za orgle

$$
1964
$$

Kombinacija za flavto in klavir

Profili (orkester)

3: 2 za tolkala

Fluktuacije za komorni ansambel

Utrinki ob Bachovem imenu za klavir

Mali nokturno za klavir

Trije nokturni za flavto in vibrafon

Vzporedja za klavir in godalni orkester

\section{5}

Konstanta in sekvence za klavir

(Ne)-simetrija za klavir

Odmevi za flavto in orkester

Circulations za harfo

\section{6}

Dialog in simfonija (flavta, čembalo)

Tri skladbice za Polonco za klavir

Preludij in vrnitve za klavir

Ciklus za klavir

$+:-z a$ klavir in godala

Antiparalele za klavir in orkester

Finale za orkester

Prolog - dialog - epilog (flavta, klarinet, fagot)

Trije pastoralčki (flavta, čembalo; pogrešano) 
1967

13. januar

28. februar

6. april

14. april

22. julij

30. oktober

29. november

19. december

8. januar

20. januar

15. februar

23. julij

5. november

10. maj

12. avgust

21. november

12. december

29. december

25. julij

2. avgust

21. avgust

18. december

16. februar

6. marec

17. april

14. avgust

31. avgust

3. december

9. december

13. december

11. januar

18. april

24. april

29. julij

10. oktober

19. december

9. januar

6. februar

6. februar

16. marec

10. april

14. junij
Inventiones pastorales (orgle)

Nihanja (flavta, komorni ansambel)

Figura $v$ miniaturah za violončelo in klavir

Breve za klarinet in klavir

Dva nokturna za kitaro

Impulzi za oboo in harfo

Kristalni gozd (scenska glasba; komorni ansambel)

Gibanja za klavir

\section{8}

Kanoni za 2 ali 3 glasove (mladinski zbor)

Ocene za klavir

Polygram za violo in klavir

Simfonija 68 (orkester)

Portret za harfo in komorni ansambel

$$
1969
$$

Nasprotja za flavto in orkester

Con sordino za trobento, pozavno in klavir

Triptychon za godalni kvartet

Akrostih za klavir

$1+1=1$ za klavir

1970

Simfonija med klavirjem in orkestrom

Quatre thèmes pour M. Albrespic (enoglasno)

Ekstremi za solo violino

Colloquium (harfa, godalni kvartet)

1971

Dvojica za klavir

Pogled (kljunasta flavta, čembalo)

Signali za klavir in ansambel

Sinteze za rog in 3 orkestrske grupe

Inverzija za čelo in klavir

Acuta za orgle

Pastoral za blokflavto in klavir

Uspavanka (kljunasta flavta, klavir)

\section{2}

Štiriročno za klavir

Simfonični portret (orkester)

Trije nokturni za kontrabas.

Thème donné za pozauno in ansambel

Solo za kontrabas

Trije preludiji za klavir

\section{3}

Transferences za harfo in tolkala

Uspavanka (mladinski zbor)

Žabe (mladinski zbor)

Ex uno (dva klavirja, tolkala)

Improvizacije za harfo

Trije preludiji za čembalo 


\section{MUZIKOLOŠKI ZBORNIK • MUSICOLOGICAL ANNUAL XXXV}

17. november

19. november

9. april

23. avgust

19. september

20. september

30. september

9. november

26. november

19. december

17. januar

31. januar

27. marec

31. julij

13. avgust

30. avgust

22. november

31. januar

28. maj

6. oktober

9. oktober

16. oktober

23. oktober

3. junij

28. junij

15. julij

21. oktober

27. oktober

30. november

20. december

30. december

21. januar

3. marec

8. april

18. julij

30. avgust

14. oktober

9. november

21. november

6. februar

22. junij

23. avgust

29. september
Duo za oboo in orkester

Etuda za flavto solo

\section{4}

Séquence des séquences (komorni ansambel)

Koncert za violončelo in orkester

Odgovori (pihalni kvintet)

Trojica (klavir)

Epizoda (tolkala)

Enica (klavir)

Pianissimo (komorni ansambel)

Elegija za violino in kontrabas

Simpozij za tolkala

1975

Jubilejna uvertura (orkster)

Lekcija za pihala, trobila in tolkala

Nuances za kontrabas in godalni kvartet

Aulofonia (oboa ali angleški rog, klavir)

Klavir za dva (klavir štiriročno)

Sounds (flavta, harfa)

Partitura (kljunasta flavta, violina, violončelo, klavir)

1976

Diagram za tolkala

Koncert za kontrabas in orkester

Coniunctio za trombon in orgle

Fragmenti za fagot

Sporočilo za violino solo

Koncert za tubo in orkester

1977

Nokturno (komorni orkester)

Elementi (kvintet trobil)

Introitus solemnis (kvintet trobil, orgle)

Pentagon (pihalni kvintet in 4 orkestrske skupine)

Fantazija za čembalo

Bravničar: Kralj Matjaž ( 3 trobente, 4 rogovi, 3 tromboni, tuba)

Kadenca za solo violončelo

Reminiscence 37- 77(godalni trio)

$$
1978
$$

Rondeau za violino in kitaro

À quattro (kvartet violončelov)

Rondò variato za kontrabas in kitaro

Poliptih (orkester)

Salpinx (mala trobenta, klavir)

Koncert za fagot in orkester

Po tipkah (klavir)

Molekule za klavir

1979

Opus $X$ (komorni ansambel)

Duo concertante za flavto, harfo, godala in tolkala

Violoncello solo

Pogovor za godalni kvartet 


\section{MUZIKOLOŠKI ZBORNIK • MUSICOLOGICAL ANNUAL XXXV}

3. oktober

4. februar

2. junij

2. julij

9. september

25 . oktober

22. november

22. november

6. april

16. maj

5. avgust

10. oktober

18. november

24. februar

8. april

25. maj

8. julij

29. september

9. oktober

1. december

6. maj

15. junij

21. september

5. oktober

22. oktober

29. oktober

8. februar

22. februar

5. marec

5. april

18. junij

1. september

16. oktober

15. marec

28. maj

19. junij

1. oktober

2. oktober

29. november

4. marec

18. april

12. junij
Pet minut za violončelo in čembalo

1980

Concerto à becco (kljunasta flavta, komorni orkester)

Dialog za klavir in orkester

Toccata za klavir

$2 \times 2$ za klavir štiriročno

Triplum (pihala, trobila, tolkala)

Diminuendo (klarinet, klavir)

Crescendo (klarinet, klavir)

\section{1}

Sto taktov (godalni kvartet)

Chordophonia (klavirski kvartet)

Koncert za 2 klavirja in orkester

A-CIs-fonia (klavir)

$H E-A L$ (flavta, klavir)

\section{2}

Güttler: Ko sem pod oljkami (flavta, violina I, violina II, viola, violončelo)

Kantilena (violina, orgle)

Studio (basovska kljunasta flavta, violina, violončelo, klavir)

Organofonia (orgle, orkester)

Med $G$ in $H$ (oboa, harfa)

Quadruplum za orgle štiriročno

Šest miniatur (pihalni trio)

\section{3}

Koncert za orgle in orkester

Dual (trobenta, orgle)

Za harmoniko

Concerto doppio (kljunasta, prečna flavta, orkester)

Nokturno (kvartet flavt)

Variacije na pesem "Tito naš tovariš" (kljunasta flavta, klavir)

\section{4}

Syrigma (kljunasta flavta)

Stiri invencije (kvartet trombonov)

Solo da trombone

Tri srca (violina, rog, klavir)

Srečanje za harmonikarski orkester

Nihil obstat (klavir)

Concerto profano (orgle, orkester)

$$
1985
$$

Miniature za flavto in gambo

$T I L-E D$ (rog, violončelo)

Koncert za trobento in orkester

Eikón (orgle)

Štirje utrinki (violina, harfa)

Tokata (ksilorimba, vibrafon, klavir)

\section{6}

Zakaj pa ne (harmonikarski orkester)

Viribus unitis (violina, kitara, harmonika)

Izpoved (orkester) 


\section{MUZIKOLOŠKI ZBORNIK • MUSICOLOGICAL ANNUAL XXXV}

\section{9. junij \\ 27. september \\ 24. oktober \\ 19. novemebr}

31. januar

5. februar

14. februar

13. marec

30. marec

2. maj

13. maj

30. maj

4. avgust

21. avgust

24. september

29. september

?

\section{3. januar \\ 16. februar \\ 29. februar}

30. april

9. maj

25. julij

3. avgust

16. avgust

16. september

20. september

24. november

2. december

31. januar

16. februar

7. marec

30. marec

27. april

29. maj

6. julij

27. julij

19. avgust

19. september

22. september

6. november

13. november

27. november

26. januar

14. februar

8. marec
Ernönek za harmoniko

Apantesis (trobenta, rog, klavir)

A. D. 1986 (orgle)

Kolovrat za orkester violin in klavir

\section{7}

Štiri za štiri (kvartet kljunastih flavt)

Tako naj bo (klarinet, fagot, klavir)

Forte-piano (viola, klavir)

Eirene (viola da gamba)

Trikrat (violončelo, kitara)

Tri za tri (trio kljunastih flavt)

Sonata za klavir štiriročno

Mrak: Chrysippos (scenska glasba; kljunasta flavta)

Nekoliko drugače (pihalni orkester)

Vedno znova (fagot, klavir)

Svobodni dialog (orkester)

Sintaksa (violončelo, klavir)

Koncert za kontrabasovsko tubo (tuba, klavir; pogrešano)

\section{8}

Dvoje oči (harfa, klavir)

Trije kolegi (flavta, violončelo, klavir)

Koncert za violino, violončelo in orkester (part za violončelo je prirejen iz solističnega parta viole)

Slovenski filharmoniji (orkester)

To je možno (kljunasta flavta, kontrabasovska tuba)

Trojka (flavta, angleški rog, triangel)

(Trikotnik) Triangulum (marimbafon)

Clar-perc (klarinet, tolkala)

$S K T$ (kvintet trobil)

Kvartet (flavta, violina, violončelo, čembalo)

Meditatio de Sancta Trinitate (orgle)

Pax et bonum (orgle)

$$
1989
$$

Hagios Athanatos (orgle)

Keratofonia (rog)

Avizo (orgle)

Šest etud (kljunasta flavta)

Doživetje (orgle, tolkala)

Pedale tenuto (klavir)

Trio za flavto, violo in kitaro

$S T A-S P A R-E C K$ (flavta, basovski klarinet, klavir)

Ob klavirju (klavir)

Pismo (orkester)

Trio za flavto, violino in kitaro (predelava parta viole za violino; gl.

Trio za flavto, violo in kitaro)

Octoginta (klavir)

Potoki (flavta)

Zahvala za kljunasto flavto

1990

$K I-R I-$ fonia (trombon, pihalni kvintet)

$N M F$ (klavir)

$D D Z$ (pihalni trio) 
31. marec

27. april

9. maj

23. maj

29. maj

20. junij

25. junij

22. avgust

28. november

23. januar

5. februar

28. februar

29. april

19. julij

1. avgust

19. avgust

27. avgust

21. november

27. november

11. januar

3. februar

4. marec

1. april

2. april

30. april

22. maj

15. julij

19. avgust

4. september

16. oktober

12. november

25. november

2. december

21. december

20. februar

13. marec

5. maj

22. maj

20. julij

27. julij

17. avgust

3. september

20. september

6. november

10. december

14. januar

7. marec

7. april
Trije trenutki za kitaro

ABSSA (kljunasta flavta)

Uspavanka za Nevo (klavir)

Nanga - Parbat za sopransko kljunasto flavto

Septuaginta (orgle)

Sto let za kljunasto flavto

$D D$ : 70 (klavir štiriročno)

Trojni koncert (oboa, klarinet, fagot, orkester)

Pentafonia (kljunasta flavta, godalni kvartet)

\section{1}

Duplex (trombon, klavir)

$K I-R I$-fonia variata (trombon, kvintet trobil)

Dilema (klarinet, klavir)

Per aspera ad astra (orkester)

Duo (flavta, oboa)

Tri misli (harfa)

Ora et labora (orgle)

Križ- kraž (klavir)

Dvojčki (dva violončela)

Arcofonia (violina, klavir)

\section{2}

Soneti nesreče (recitator, kljunasta flavta)

Cum jubilo (kvintet trobil)

AVS (trobenta, rog, trombon)

Korajža velja (violončelo, klavir)

Pogumno naprej (klarinet, klavir)

Confinium (orgle)

In piam memoriam (oboa, viola, harfa)

Inavguracija (harmonika, orgle)

Extension (basovski klarinet)

Tako in tako (kontrabas, klavir)

ZOMI (fagot, klavir)

Pro tribus (flavta, kontrabas, klavir)

Klavir naj začne (klarinet, violončelo, klavir)

Repraesentatio (trobenta, klavir)

Ostinato (klarinet, klavir)

\section{3}

Discessus ( 3 trobente, 3 rogovi, 3 tromboni)

Celeia laboribus suis gaudens (godalni orkester)

Sol(tanto) (flavta, klavir)

Cinque o quattro (kvartet oz. kvintet flavt)

Od-do (klavir)

Gratulatio (klavir)

Brez strahu (klarinet)

$L J-O-T$ (orgle)

Po koncertu (harfa)

Perchè (klavir)

Zvočni svet dveh klavirjev in orkestra

1994

$A S A E$ (orgle)

$A S$ (pihala, trobila, tolkala)

Ancia doppia (angleški rog) 
19. april

7. maj

28. maj

21. julij

30. avgust

13. september

3. novemebr

9. november

23. november

9. februar

14. marec

8. april

12. april

4. maj

23. maj

11. julij

13. julij

26. julij

17. avgust

6. september

15. september

27. september ?
23. januar
15. februar
29. februar
14. marec
18. april
4. maj
? maj
29. maj
1. julij
14. avgust
21. avgust
6. september
30. septemebr ?

\section{1. februar \\ 20. februar \\ 21. marec \\ ?}

18. april

29. april

13. maj

6. junij

15. julij

18. avgust

6. september

9. oktober
Kontrafonia (kvartet kontrabasov)

Pojoče strune (dve violini, klavir)

Brez meja (kvartet flavt, angleški rog)

Živio SGS̆! (trobenta, orkester)

Trije pari (rog, tuba)

$D-S$ (klarinet, klavir)

Luwigana 1144 (klarinet, violončelo, klavir)

$A m-B e$ (klavir štiriročno)

Radius sonans (angleški rog, klavir)

$$
1995
$$

Simfonija Pietà (orkester)

Gre zares (dva klavirja)

Dovolj za zdaj (violončelo, klavir)

Pika na $i$ (klavir)

Caesar vincit (fagot)

Ne bojiva se (dva klavirja)

Zares in za šalo (klavir)

$V$ soglasju (orgle, tenorska gamba, basovska gamba)

Concerto da camera (orgle, godalni orkester)

Vivat, crescat, floreat (klavir)

Klar-kvar (kvartet klarinetov)

Osmerica (dva klavirja štiriročno)

Saxofonia (kvartet saksofonov)

$P L$ (klavir; pogrešano)

\section{6}

Koncertantni diptih (klavir, orkester)

Totus tuus (orgle)

Kontra $B$ (fagot, godalni kvintet)

In modo tedesco (marimba)

Ves Tvoj (klavir; gl. Totus tuus)

Fonosaxia (kvartet saksofonov)

Credo (orgelske improvizacije posvečene papežu Janezu Pavlu II)

Decem anni prospere peracti (klavirski kvartet)

$V$ soglasju (klarinet, harmonika)

Fyrir Rannveig - con amore (oboa d'amore, viola d'amore)

Vis vim vi superat (klavir, tolkala)

Pušeljc (klavir)

Septet (flavta, oboa, klarinet, fagot, trobenta, rog, trombon)

$X Y$ (klavir; pogrešano)

1997

Kontra-koncert (orgle, sekstet saksofonov, orkester)

$\checkmark$ dvoje (dve violini)

Kongresni avizo = Praeludium (flavta, harfa)

Kongresni avizo za klarinet in harfo (gl. Kongresni avizo $=$

Praeludium)

Akatombo (godalni kvartet)

80 (viola)

Ob sliki Maksima Sedeja (klavir)

Quinque sumus (marimbafon, godalni kvartet)

Kołysanka dla maleńkiego Marcina (klavir)

Unda maris (flavta, klarinet, klavir)

Izpolnjena želja (dve harmoniki)

Pihalni diptih (pihalni trio) 
MUZIKOLOŠKI ZBORNIK • MUSICOLOGICAL ANNUAL XXXV

28. oktober

19. november

26. januar

17. februar

9. marec

14. marec

17. marec

7. julij

28. oktober
Forte-piano (TAKA-SO) (klavir)

Jubilejni crescendo (orkester)

$$
1998
$$

Trošt: Stati inu obstati (orgle)

Tetrafonia (godalni kvartet)

Štirikrat štiri strune (godalni kvartet)

Robbov vodnjak (kljunasta flavta, zvončki, ksilofon)

Kongresni avizo 98(flavta, klavir; gl. Kongresni avizo = Praeludium)

Viva memoria (violončelo, klavir)

Colloquium quinquae virorum (klavirski kvintet) 
KAZALO ZASEDB

\section{INŠTRUMENTALNE ZASEDBE}

- angleški rog:

- citre:

- čembalo:

- fagot:

- flavta:

- harfa:

- harmonika:

- kitara:

- klarinet:

- klavir:

\section{Posamezni inštrumenti}

\author{
Ancia doppia
}

Koral za citre $v$ c-molu, op. $10 a$

Fantazija za čembalo

Trije preludiji za čembalo

Caesar vincit

Fragmenti za fagot

Ekspanzija za altovsko flavto

Etuda za flavto solo

Potoki

Circulations za harfo

Improvizacije za harfo

Po koncertu

Sonatina za harfo

Tri misli

Trije preludiji za harfo

Ernönek za harmoniko

Za harmoniko

Dva nokturna za kitaro

Trije trenutki za kitaro

Brez strahu

Extension (basovski klarinet)

A-CIs-fonia

[Adagio, non troppo]

Akrostih za klavir

Bagatele za klavir

Ciklus za klavir

II. suita za klavir

Dvojica

$1+1=1$ za klavir

Enica

Fantasia per pianoforte

Fantazija za klavir

Forte-piano (TAKA-SO)

Gibanja za klavir

Gratulatio

Kotysanka dla maleńkiego Marcina

Konstanta in sekvence za klavir

Koračnica po napevih slovenskih narodnih pesmi, op. 9

Križ- kraž

Mala suita za klavir

Mali nokturno za klavir

Marcia funebre, op. 6

Miniature za klavir

Molekule za klavir

Mouvement sonatique, op. 18

(Ne) - simetrija za klavir

Nihil obstat

$N M F$ 
$N N$

Ob klavirju

Ob sliki Maksima Sedeja

Ocene za klavir

Octoginta

Od-do

Pastorale

Pedale tenuto

Pentektasis za klavir

Perchè

Petite phantasie, op. 24

Pika na $i$

$P L$

Po tipkah

Preludij

Preludij in vrnitve za klavir

I. sonata, op. 7

Pušeljc

Ricercare per pianoforte

Rondino za klavir

Sarkazmi za klavir

Scherzo za klavir

Shakespeare: Sen kresne noči, scenska glasba (z recitatorjem)

Sonata quasi una phantasia, [op. 25]

Sonatina

Suita za klavir (1936 ali 1937)

Suita za klavir (1942)

Šest malih preludijev za klavir

Tema z variacijami

Toccata

Toccata za klavir

Tokata

Tri skladbe

Tri skladbice za Polonco za klavir

Trije preludiji za klavir

Trojica

Uspavanka za Nevo

Utrinki ob Bachovem imenu za klavir

Variacije za klavir

Ves tvoj (gl. Totus tuus)

Vivat, crescat, floreat

$X Y$

Zares in za šalo

- klavir štiriročno:

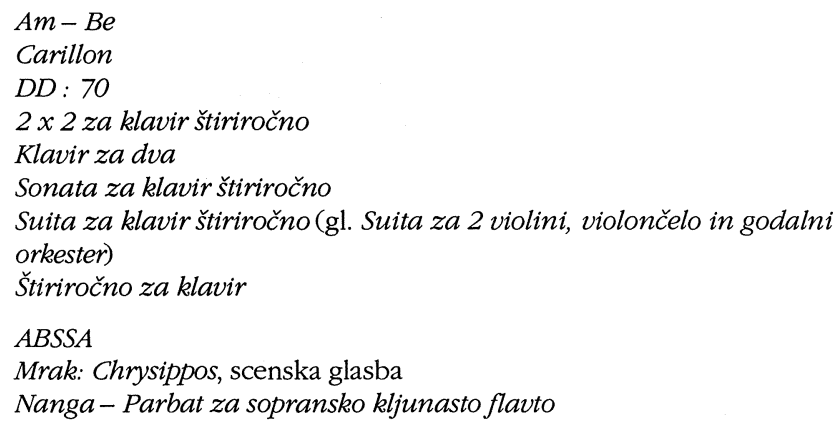

ABSSA

Mrak: Chrysippos, scenska glasba

Nanga-Parbat za sopransko kljunasto flavto

- kljunasta flavta: 


\section{MUZIKOLOŠKI ZBORNIK • MUSICOLOGICAL ANNUAL XXXV}

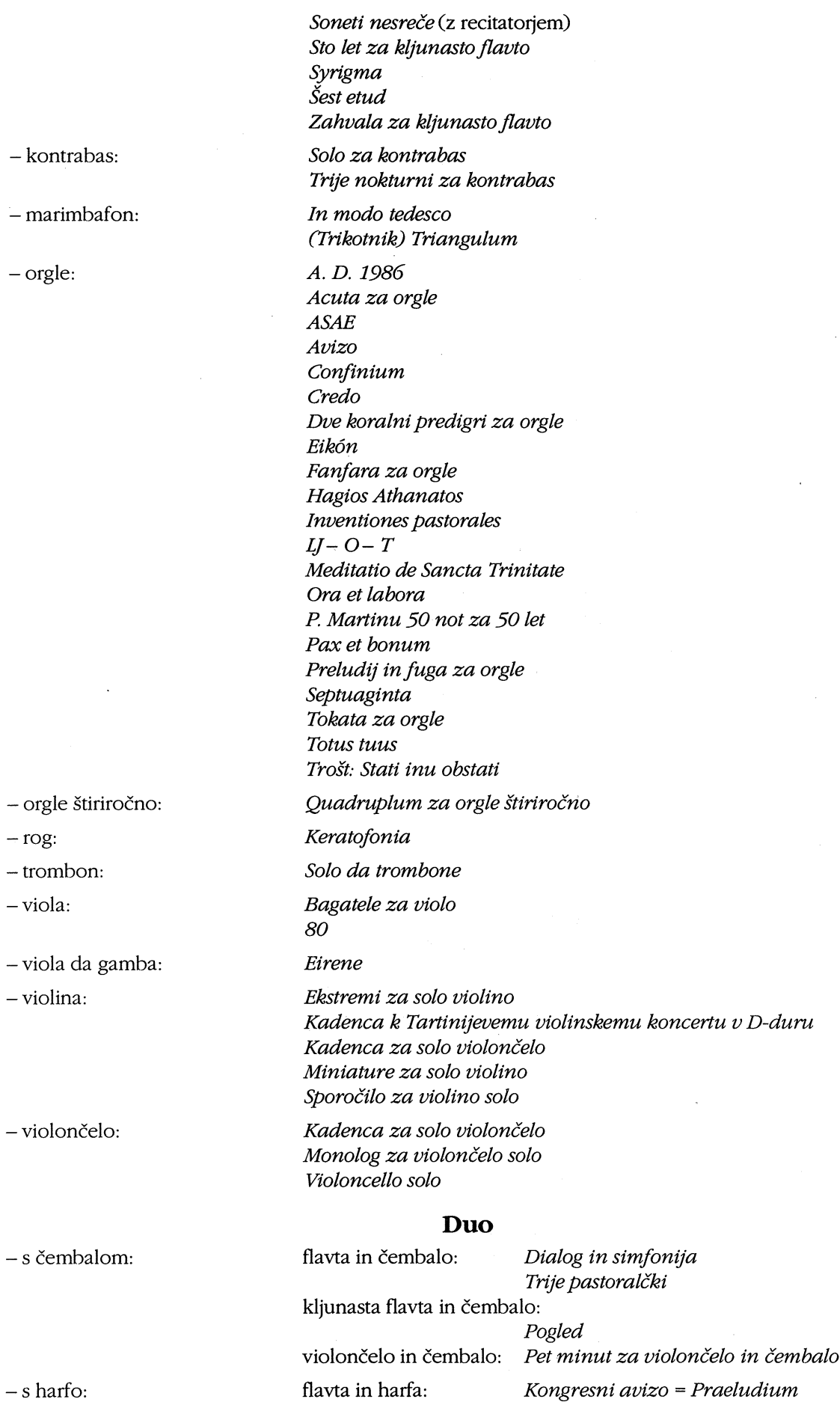




\section{MUZIKOLOŠKI ZBORNIK • MUSICOLOGICAL ANNUAL XXXV}

\begin{tabular}{|c|c|c|}
\hline & & Sounds \\
\hline & & Trije pastoralčki za altovsko flavto in harfo \\
\hline & klarinet in harfa: & $\begin{array}{l}\text { Kongresni avizo za klarinet in harfo } \\
\text { (gl. Kongresni avizo = Praeludium) }\end{array}$ \\
\hline & oboa in harfa: & Impulzi za oboo in harfo \\
\hline & & Med $G$ in $H$ \\
\hline & violina in harfa: & $\begin{array}{l}\text { Intermezzo za violino in harfo } \\
\text { Štirje utrinki }\end{array}$ \\
\hline - s kitaro: & $\begin{array}{l}\text { kontrabas in kitara: } \\
\text { violina in kitara: } \\
\text { violončelo in kitara: }\end{array}$ & $\begin{array}{l}\text { Rondò variato za kontrabas in kitaro } \\
\text { Rondeau za violino in kitaro } \\
\text { Trikrat }\end{array}$ \\
\hline -s klavirjem: & angleški rog in klavir: & $\begin{array}{l}\text { Aulofonia (oboa ali angleški rog) } \\
\text { Radius sonans }\end{array}$ \\
\hline & fagot in klavir: & Burleska za fagot in klavir \\
\hline & & Vedno znova \\
\hline & & ZOMI \\
\hline & flavta in klavir: & Dve uspavanki za flavto in klavir \\
\hline & & $H E-A L$ \\
\hline & & Kombinacija za flavto in klavir \\
\hline & & $\begin{array}{l}\text { Kongresni avizo } 98 \text { (gl. Kongresni avizo }= \\
\text { Praeludium) }\end{array}$ \\
\hline & & Sol(tanto) \\
\hline & harfa in klavir: & Dvoje oči \\
\hline & klarinet in klavir: & Breve za klarinet in klavir \\
\hline & & Crescendo \\
\hline & & $D-S$ \\
\hline & & Dilema \\
\hline & & Diminuendo \\
\hline & & Ostinato \\
\hline & & Pogumno naprej \\
\hline & & Sonata za klarinet in klavir \\
\hline & & Sonatina za klarinet in klavir \\
\hline & kljunasta flavta in klavir: & Pastoral za blokflavto in klavir \\
\hline & & Uspavanka \\
\hline & & Variacije na pesem "Tito naš tovariš" \\
\hline & kontrabas in klavir: & Tako in tako \\
\hline & oboa in klavir: & Aulofonia (oboa ali angleški rog) \\
\hline & & Ricercare na Merkùjevo temo za oboo in klavir \\
\hline & oboa d'amore in klavir: & 3 pastorali za oboo d'amore in klavir \\
\hline & rog in klavir: & Sonatina $z a$ rog in klavir \\
\hline & & Zvočna slika za rog in klavir \\
\hline & trobenta in klavir: & Repraesentatio \\
\hline & & Salpinx (mala trobenta) \\
\hline & trombon in klavir: & Duplex \\
\hline & tuba in klavir: & Koncert za kontrabasovsko tubo \\
\hline & viola in klavir: & Aforizmi za violo in klavir \\
\hline & & Andante za violo in klavir \\
\hline & & Forte-piano \\
\hline & & Nokturno za violo in klavir \\
\hline & & Polygram za violo in klavir \\
\hline & & Skice za violo in klavir \\
\hline & violina in klavir: & Arcofonia \\
\hline & & Cudodelna roka, op. $10 b$, uvertura \\
\hline & & Gregorjev binkoštni preludij \\
\hline
\end{tabular}




\section{MUZIKOLOŠKI ZBORNIK • MUSICOLOGICAL ANNUAL XXXV}

\begin{tabular}{|c|c|c|}
\hline & violončelo in klavir: & $\begin{array}{l}\text { Gugalni stol za violino in klavir } \\
\text { Iz Miniatur za klavir (gl. Miniature za klavir) } \\
\text { Preludij za violino in klavir } \\
\text { Sonata breve za violino in klavir } \\
\text { Variacije } \\
\text { Dovolj za zdaj } \\
\text { Figura v miniaturah za violončelo in klavir } \\
\text { Inverzija za čelo in klavir } \\
\text { Korajža velja } \\
\text { Sintaksa } \\
\text { Viva memoria }\end{array}$ \\
\hline - z orglami: & $\begin{array}{l}\text { harmonika in orgle: } \\
\text { trobenta in orgle: } \\
\text { trombon in orgle: } \\
\text { violina in orgle: }\end{array}$ & $\begin{array}{l}\text { Inavguracija } \\
\text { Dual } \\
\text { Coniunctio za trombon in orgle } \\
\text { Kantilena }\end{array}$ \\
\hline - drugo: & $\begin{array}{l}\text { dva violončela: } \\
\text { dve harmoniki: } \\
\text { dve violini: } \\
\text { flavta in fagot: } \\
\text { flavta in klarinet: } \\
\text { flavta in oboa: } \\
\text { flavta in vibrafon: } \\
\text { flavta in viola da gamba: } \\
\text { klarinet in harmonika: } \\
\text { kljunasta flavta in tuba: } \\
\text { oboa d'amore in viola d' } \\
\text { rog in tuba: } \\
\text { rog in violončelo: } \\
\text { trombon in tuba: } \\
\text { violina in kontrabas: } \\
\text { violina in violončelo: }\end{array}$ & $\begin{array}{l}\text { Dialogi za dva klavirja } \\
\text { Gre zares } \\
\text { Ne bojiva se } \\
\text { Osmerica (dva klavirja štiriročno) } \\
\text { Suita za dva klavirja } \\
\text { Dvojčki } \\
\text { Izpolnjena želja } \\
\text { V dvoje } \\
\text { Fuga in Do-maggiore, op. 12, no. } 3 \\
\text { Pet miniatur za flavto in klarinet } \\
\text { Duo } \\
\text { Trije nokturni za flavto in vibrafon } \\
\text { Miniature za flavto in gambo } \\
\text { V soglasju } \\
\text { To je možno (kontrabasovska tuba) } \\
\text { amore: } \\
\text { Fyrir Rannveig - con amore } \\
\text { Trije pari } \\
\text { TIL-ED } \\
\text { Áphiksis (Andreíou) } \\
\text { Elegija za violino in kontrabas } \\
\text { Fuga in Re-maggiore, op. 12, no. } 1\end{array}$ \\
\hline
\end{tabular}

\section{Trio}

- godalni trio (violina, viola, violončelo): $\quad$ Fuga in Do-maggiore, op. 13, no. 1 Fuga in Re-maggiore, op. 12, no. 2 Godalni trio, op. 17[a] Reminiscence 37- 77

- klavirski trio (violina, violončelo, klavir): Kolo

- klavirski trio (violina, rog, klavir): $\quad$ Balada za violino, rog in klavir, op. 29 Tri srca

- klavirski trio (klarinet, violončelo, klavir): Klavir naj začne Luwigana 1144

Trio za klarinet, violončelo in klavir

- pihalni trio (oboa, klarinet, fagot): $\quad D D Z$

Pihalni diptih

Šest miniatur

Trio za 2 oboi (oboo in klarinet) in fagot 


\section{MUZIKOLOŠKI ZBORNIK • MUSICOLOGICAL ANNUAL XXXV}

- pihalni trio (flavta, klarinet, fagot):

- trobilni trio (trobenta, rog, trombon):

- različne zasedbe s klavirjem:

- različne zasedbe:

- godalni kvartet:

- godalni kvartet + harfa:

+ kljunasta flavta:

+ kontrabas:

+ marimbafon:
Prolog - dialog - epilog

AVS

Apantesis (trobenta, rog, klavir)

Con sordino za trobento, pozavno in klavir

Pojoče strune (dve violini, klavir)

Pro tribus (flavta, kontrabas, klavir)

Sonatina za klarinet, trobento in klavir

$S T A-S P A R-E C K$ (flavta, basovski klarinet, klavir)

Tako naj bo (klarinet, fagot, klavir)

Tokata (ksilorimba, vibrafon, klavir)

Trije kolegi (flavta, violončelo, klavir)

Unda maris (flavta, klarinet, klavir)

Uspavanka za 2 violini in klavir

Bagatela (flavta, dve violi)

In piam memoriam (oboa, viola, harfa)

Tri za tri (trio kljunastih flavt)

Trio za 2 oboi (oboo in klarinet) in fagot

Trio za 2 violini in violo

Trio za flavto, violo in kitaro

Trio za pikolo, trobento in kontrafagot

Trojka (flavta, angleški rog, triangel)

$V$ soglasju (orgle, tenorska gamba, basovska gamba)

Viribus unitis (violina, kitara, harmonika)

\section{Kvartet}

Akatombo

II. godalni kvartet

Godalni kvartet

[Largo]

Pogovor za godalni kvartet

Stavek za godalni kavartet

Sto taktov

Štirikrat štiri strune

Tetrafonia

Triptychon za godalni kvartet

Colloquium

Pentafonia

Nuances za kontrabas in godalni kvartet

Quinque sumus

- klavirski kvartet (violina, viola, violončelo, klavir):

Chordophonia

Decem anni prospere peracti

- klavirski kvartet (kljunasta flavta, violina, violončelo, klavir):

Partitura

Studio (basovska kljunasta flavta)

- različne zasedbe:

Cinque o quattro (kvartet oz. kvintet flavt)

Fonosaxia (kvartet saksofonov)

Klar-kvar (kvartet klarinetov)

Kontrafonia (kvartet kontrabasov)

Kvartet (flavta, violina, violončelo, čembalo)

Kvartet $z$ a rogove

Nokturno (kvartet flavt) 


\section{MUZIKOLOŠKI ZBORNIK • MUSICOLOGICAL ANNUAL XXXV}

Potpourri Bizet-jeve opere "Carmen" (violina, dva klavirja, tolkala)

Potpourri slovenskih narodnih pesmi, op. 5 (dve violini, klavir štiriročno)

Robbov vodnjak (kljunasta flavta, zvončki, ksilofon)

Saxofonia (kvartet saksofonov)

Štiri invencije (kvartet trombonov)

Štiri za štiri (kvartet kljunastih flavt)

Uvertura Bizetjeve opere "Carmen za violino, klavir, trobento in tolkala

Variacije na "An die Freude" iz IX. Beethovenove simphonije, op. 8 (flavta, violina, dva klavirja)

\section{Kvintet}

- godalni kvintet + fagot:

Kontra B

- klavirski kvintet (violina I, violina II, viola, violončelo, klavir):

Colloqium quinquae virorum

- kvintet trobil:

Cum jubilo (trobenta I, trobenta II, rog, trombon, tuba) Elementi (mala trobenta, trobenta, rog, trombon, tuba) $S K T$ (mala trobenta, trobenta, rog, trombon, tuba)

- kvintet trobil + orgle:

$$
+ \text { trombon: }
$$

Introitus solemnis (trobenta, 2 rogova, 2 trombona)

$K I-R I-$ fonia variata (trobenta I, trobenta II, rog, trombon, tuba)

- pihalni kvintet (flavta, oboa, klarinet, rog, fagot):

Odgovori

Pihalni kvintet

Pihalni kvintet, op. 21

- pihalni kvintet (flavta, oboa, klarinet, rog, fagot) + trombon:

$K I-R I-$ fonia

- različne zasedbe:

Brez meja (kvartet flavt, angleški rog)

Cinque o quattro (kvartet oz. kvintet flavt)

Güttler: Ko sem pod oljkami (flavta, violina I, violina II, viola, violončelo)

Pianissimo (flavta, rog, violončelo, kontrabas, klavir)

\section{Septet}

- pihalni septet (flavta, oboa, klarinet, fagot, trobenta, rog, trombon):

Septet

\section{Nonet}

- nonet trobil ( 3 trobente, 3 rogovi, 3 tromboni):

\section{Discessus}

\section{Tolkala}

Epizoda

Preludij in fuga za tolkala

Simpozij za tolkala

3: 2 za tolkala

- harfa in tolkala:

Transferences za harfo in tolkala

- klarinet in tolkala:

Clar-perc

- klavir in tolkala:

Diagram za tolkala

Ex uno (dva klavirja)

Vis vim vi superat 


\section{MUZIKOLOŠKI ZBORNIK • MUSICOLOGICAL ANNUAL XXXV}

- orgle in tolkala:

- trobila:

- pihala, trobila, tolkala:

- godalni orkester

- godalni orkester

- harmonikarski orkster:

- komorni orkester:
Doživetje

\section{Orffov inštrumentarij}

Mladinske skladbe za Orffov instrumentarij

\section{Različne inštrumentalne skupine}

Bravničar: Kralj Matjaž ( 3 trobente, 4 rogovi, 3 tromboni, tuba)

AS

Lekcija za pihala, trobila in tolkala

Triplum

\section{Orkester}

Celeia laboribus suis gaudens

Divertimento.št. 3 za godalni orkester

Rondo za godalni orkester

Sedem skladb za godalni orkester

Simfonija za godalni orkester, op. 17 [b]

Sonatina

Sonatina za godala (gl. Sedem skladb za godalni orkester)

+ fagot:

Concerto piccolo za fagot in godalni orkester

+ klavir:

Concertino per pianoforte ed orchestra d'archi Kolovrat za orkester violin in klavir Mala suita za klavir in godalni orkester $+:-z a$ klavir in godala

Scherzo za klavir in godalni orkester Vzporedja za klavir in godalni orkester

+ orgle:

Concerto da camera

+ violončelo:

Adagio za violončelo in godalni orkester

+ dva klavirja:

Koncert za dva klavirja in godalni orkester Rondo za 2 klavirja in godalni orkester

+ dve violi: $\quad$ Transformacije (na Merkùjevo voščilo) za 2 violi in 10 godal

+ dve violini, violončelo:

Suita za 2 violini, violončelo in godalni orkester

Srečanje za harmonikarski orkester Zakaj pa ne

Divertimento per 2 cornetti, timpani ed archi Divertimento za 2 oboi, fagot in godalni orkester Enneafonia (flavta, klarinet, fagot, harfa, klavir, tolkala, godala) Fluktuacije za komorni ansambel (flavta, oboa, klarinet, rog, klavir, godala)

Kristalni gozd (flavta, oboa, angleški rog, klarinet, harfa, vibrafon, tolkala, godala)

Nokturno (oboa, klarinet, fagot, godala)

Opus $X$ (oboa, klarinet, rog, violina, kitara, klavir, tolkala)

Plautus: Dvojčka (flavta, klarinet, 2 fagota, 3 trobente, harfa, viola, 3 violončeli)

Ravel: Bolero, priredba (kljunasta flavta, klarinet, fagot, rog, saksofon, trobenta, violina, kontrabas)

Séquence des Séquences (flavta, klarinet, rog, boben, godala) 


\section{MUZIKOLOŠKI ZBORNIK • MUSICOLOGICAL ANNUAL XXXV}

\begin{tabular}{|c|c|c|}
\hline \multirow[t]{7}{*}{ - komorni orkester } & + flavta: & Nihanja (tolkala, harfa, godala) \\
\hline & + harfa: & $\begin{array}{l}\text { Portret za harfo in komorni ansambel (flavta, } \\
\text { klarinet, rog, tolkala, godala) }\end{array}$ \\
\hline & + kljunasta flavta: & Concerto à becco (rogova, godala) \\
\hline & + klavir: & $\begin{array}{l}\text { Signali za klavir in ansambel (flavta, oboa, } \\
\text { klarinet, fagot, rog, godala) }\end{array}$ \\
\hline & + rog: & $\begin{array}{l}\text { Apel za rog in komorni ansambel (flavta, } \\
\text { klarinet, harfa, godala) }\end{array}$ \\
\hline & + trombon: & $\begin{array}{l}\text { Theme donné za pozavno in ansambel (flavta, } \\
\text { klarinet, fagot, tolkala, violina, viola, violončelo) }\end{array}$ \\
\hline & + viola: & Andante za violo in mali orkester(?) \\
\hline - komorni orkester & + flavta, harfa: & $\begin{array}{l}\text { Duo concertante za flavto, harfo, godala in } \\
\text { tolkala }\end{array}$ \\
\hline - pihalni orkester: & \multicolumn{2}{|l|}{ Nekoliko drugače } \\
\hline - simfonični orkester: & $\begin{array}{l}\text { Finale za orkester } \\
\text { Fuga, [op. 26] } \\
\text { Intrada } \\
\text { Izpoved } \\
\text { Jubilejna uvertura } \\
\text { Jubilejni crescendo } \\
\text { Koral in tokata } \\
\text { Momenti riflessivi, op. } 2 \\
\text { La mort de loup, op. } 28 \\
\text { Mouvement musical cor } \\
\text { Mouvement symphoniqu } \\
\text { Mouvements symphoniq } \\
\text { Mrtvaški ples } \\
\text { Musica funebre } \\
\text { Musiques funèbres } \\
\text { Nevihta, op. 19 } \\
\text { Per aspera ad astra } \\
\text { Pismo } \\
\text { Ples podzemskih duhov, } \\
\text { Poliptih } \\
\text { Profili } \\
\text { Simfonia orientale, op. } \\
\text { Simfonični portret } \\
\text { Simfonietta } \\
\text { Simfonija II. } \\
\text { Simfonija } 68 \\
\text { Simfonija Pietà } \\
\text { Simfonija I. } \\
\text { Slovenski filharmoniji } \\
\text { Svobodni dialog } \\
\text { III. simfonija }\end{array}$ & $\begin{array}{l}7 \\
\text { fuga, op. } 16 \\
\text { ues no. } 3 \text {, op. } 20 \\
\text { et } 2, \text { op. } 15 \\
\text { op. } 11, \text { mali orkester } \\
23\end{array}$ \\
\hline \multirow[t]{3}{*}{ - simfonični orkester } & + fagot: & Koncert za fagot in orkester \\
\hline & + flavta: & $\begin{array}{l}\text { Nasprotja za flavto in orkester } \\
\text { Odmevi za flavto in orkester }\end{array}$ \\
\hline & + klavir: & $\begin{array}{l}\text { Antiparalele za klavir in orkester } \\
\text { Dialog za klavir in orkester } \\
\text { Koncert za klavir in orkester } \\
\text { Koncert za klavir in veliki orkester, op. } 14\end{array}$ \\
\hline
\end{tabular}




\section{MUZIKOLOŠKI ZBORNIK • MUSICOLOGICAL ANNUAL XXXV}

\begin{tabular}{|c|c|c|}
\hline & & $\begin{array}{l}\text { Koncertantni diptih } \\
\text { Simfonija med klavirjem in orkestrom }\end{array}$ \\
\hline & + kontrabas: & Koncert za kontrabas in orkester \\
\hline & + oboa: & Duo za oboo in orkester \\
\hline & + orgle: & $\begin{array}{l}\text { Concerto profano } \\
\text { Koncert za orgle in orkester } \\
\text { Organofonia }\end{array}$ \\
\hline & + rog: & Sinteze za rog in 3 orkestrske grupe \\
\hline & + tolkala: & Koncertantna glasba za pavke in orkester \\
\hline & + trobenta: & $\begin{array}{l}\text { Concertino za trobento in orkester } \\
\text { Koncert za trobento in orkester } \\
\text { Živio SGS̆! }\end{array}$ \\
\hline & + tuba: & Koncert za tubo in orkester \\
\hline & + violončelo: & Koncert za violončelo in orkester \\
\hline - simfonični orkester & + dva klavirja: & $\begin{array}{l}\text { Koncert za } 2 \text { klavirja in orkester } \\
\text { Zvočni svet dveh klavirjev in orkestra }\end{array}$ \\
\hline & + kljunasta flavta, preč & $\begin{array}{l}\text { Clavta: } \\
\text { Concerto doppio }\end{array}$ \\
\hline & + orgle, sekstet saksof & Kontra-koncert \\
\hline & + violina, viola: & Koncert $z$ a violino in violo \\
\hline & + violina, violončelo: & $\begin{array}{l}\text { Koncert za violino, violončelo in orkester (gl. } \\
\text { Koncert za violino in violo) }\end{array}$ \\
\hline & + oboa, klarinet, fagot & $\begin{array}{l}\text { ihalni trio): } \\
\text { Trojni koncert }\end{array}$ \\
\hline & + pihalni kvintet: & $\begin{array}{l}\text { Pentagon (pihalni kvintet in } 4 \text { orkestrske } \\
\text { skupine) }\end{array}$ \\
\hline VOKALI & V VOKALNOINŠTI & UMENTALNE ZASEDBE \\
\hline - dvoglasno: & $\begin{array}{l}\text { Himna brigade } \\
\text { Na Balkanu }\end{array}$ & \\
\hline - enoglasno: & $\begin{array}{l}\text { Na sve načine } \\
\text { Quatre thèmes pour } M \\
\text { Zidari }\end{array}$ & Albrespic \\
\hline - glas in klavir: & $\begin{array}{l}\text { Cala la notte (gl. Noč } \\
\text { Ewig treu } \\
\text { Noč prihaja, op. } 22 \\
\text { Pod gradom } \\
\text { Vprašanje }\end{array}$ & ihaja, op. 22) \\
\hline - glas in orgle: & $\begin{array}{l}\text { Cantabo Domino } \\
\text { Deus Israël conjungat }\end{array}$ & \\
\hline - mešani zbor: & $\begin{array}{l}\text { Diptychon orationis } \\
\text { Sv. Benedikt [I] } \\
\text { Sv. Benedikt [II] } \\
\text { V mesečini } \\
\text { Venturini: Jagnje božj }\end{array}$ & \\
\hline - mešani zbor in orgle: & Missa in Mi-mag[g]ior & (E-dur), op. 9 \\
\hline - mešani zbor in orkester: & Dies irae & \\
\hline
\end{tabular}




\section{MUZIKOLOŠKI ZBORNIK • MUSICOLOGICAL ANNUAL XXXV}

- mladinski zbor:

- moški zbor:

- otroški zbor:

- solisti, ansambel:

- solisti, zbor, orkester:

- ženski zbor:

- Ženski zbor in orgle:
Beati immaculati za deški zbor

Iz "Cicibana" za mladinski zbor

Kanoni za 2 ali 3 glasove

Mladinske pesmi (pogrešano)

Uspavanka

Žabe

Ot'če naš'

[Vse najboljše, dragi Eto]

Mali Jožek (pogrešano)

Čudodelna roka, op. 2 (fagot, trobenta, mandolina, violina, klavir) Kako je pridna Micka prišla v nebesa, op. 1 (trobenta občasno, klavir) Orpheus in Euridika, op. 4 (violina I, violina II ad libitum, klavir I, klavir II, pavke)

Paževa usoda, op. 3 (klavir, pavke)

Requiem za deški glas, moški zbor in 11 instrumentov

2 moteti in honorem $S$. Caeciliae

Kanizij, Kanizij

Loquebar za ženski zbor

Zvonovi zvonijo

Beati immaculati

Psalm 50 za ženski zbor in orgle

Tebe ljubi moja duša

- ženski zbor, dve violi, violončelo: Veni Sancte Spiritus 


\section{KAZALO OBLIK IN ZVRSTI}

- bagatela:
- balada:
- burleska:
- divertimento:
- elegija:
- elektroakustična glasba:
- etuda:
- fanfara:
- fantazija:

- filmska glasba:

- finale:

- fuga:

- improvizacija:

- intermezzo:

- intrada:

- invencija:

- kadenca:

- kanon:

- kantata:
Bagatela (flavta, dve violi)

Bagatele za klavir

Bagatele za violo

Balada za violino, rog in klavir, op. 29

Burleska za fagot in klavir

Divertimento per 2 cornetti, timpani ed archi

Divertimento št. 3 za godalni orkester

Divertimento za 2 oboi, fagot in godalni orkester

Elegija za violino in kontrabas

Konkretna študija št. 1 za magnetofonski trak Konkretna študija št. 2 za magnetofonski trak

Etuda za flavto solo

Šest etud (kljunasta flavta)

Fanfara (gl. Sedem skladb za godalni orkester)

Fanfara (trio flavt, činele, boben; gl. Mladinske skladbe za Orffov

instrumentarij)

Fanfara za orgle

Fantasia per pianoforte

Fantazija za čmbalo

Fantazija za klavir

Petite phantasie, op. 24 (klavir)

Mrtvaški ples (orkester)

Finale (flavta, zvončki, ksilofon, trikotnik, činele, paličice, boben, pavke; gl. Mladinske skladbe za Orffov instrumentarij)

Finale za orkester

Fuga, [op. 26] (orkester)

Fuga in Do-maggiore, op. 12, no. 3 (flavta, fagot)

Fuga in Do-maggiore, op. 13, no. 1 (godalni trio)

Fuga in Do-maggiore, op. 13, no. 2 (?)

Fuga in Re-maggiore, op. 12, no. 1 (violina, violončelo)

Fuga in Re-maggiore, op. 12, no. 2 (godalni trio)

Fuga in Sol-maggiore con preludio, op. 13, no. 3 (?)

Mouvement musical con fuga, op. 16 (komorni ansambel)

Preludij in fuga za orgle

Preludij in fuga za tolkala

Credo (orglelske improvizacije)

Improvizacije za harfo

Intermezzo (gl. Sedem skladb za godalni orkester)

Intermezzo za violino in harfo

Intrada (orkester)

Inventiones pastorales (orgle)

Štiri invencije (kvartet trombonov)

Kadenca $k$ Tartinijevemu violinskemu koncertu v D-duru (violina)

Kadenca za solo violončelo

Kanon (gl. Sedem skladb za godalni orkester)

Kanon (zvončki, ksilofon; gl. Mladinske skladbe za Orffov instrumentarij)

Kanoni za 2 ali 3 glasove (mladinski zbor)

Dies irae (mešani zbor, orkester) 
- kolo:

- koncert:

- koncertantna glasba:

- koračnica:

- koral:

- maša:

- miniatura:

- množična pesem:
Kolo (klavirski trio)

Concertino per pianoforte ed orchestra d'archi Concertino za trobento in orkester Concerto à becco (kljunasta flavta, komorni orkester) Concerto da camera (orgle, godalni orkester) Concerto doppio (kljunasta flavta, prečna flavta, orkester) Concerto piccolo za fagot in godalni orkester Concerto profano (orgle, orkester) Koncert za dva klavirja in godalni orkester Koncert za 2 klavirja in orkester Koncert za fagot in orkester Koncert za klavir in orkester Koncert za klavir in veliki orkester, op. 14 Koncert za kontrabas in orkester Koncert za kontrabasovsko tubo Koncert za orgle in orkester Koncert za trobento in orkester Koncert za tubo in orkester Koncert za violino in violo Koncert za violino, violončelo in orkester (gl. Koncert za violino in violo) Koncert za violončelo in orkester

Kontra-koncert (orgle, sekstet saksofonov, orkester) Simfonija med klavirjem in orkestrom Trojni koncert (oboa, klarinet, fagot, orkester)

Duo concertante za flavto, harfo, godala in tolkala Koncertantna glasba za pavke in orkester Koncertantni diptih

Koračnica (gl. Bagatele za klavir) Koračnica (violina, klavir; gl. Miniature za klavir)

Koračnica (trikotnik, činele, paličice, boben; gl. Mladinske skladbe za Orffov instrumentarij)

Koračnica po napevih slovenskih narodnih pesmi, op. 9(klavir) Marcia funebre, op. 6 (klavir)

Žalna koračnica (duo flavt, pavke, boben; gl. Mladinske skladbe za Orffov instrumentarij)

Corale + Siciliana (gl. Suita za 2 violini, violončelo in godalni orkester) Koral (gl. Bagatele za klavir)

Koral (gl. Mala suita za klavir)

Koral (gl. Sedem skladb za godalni orkester)

Koral-Siciliana (klavir štiriročno; gl. Suita za 2 violini, violončelo in godalni orkester)

Koral in tokata (orkester)

Koral za citre $v$ c-molu, op. $10 a$

Missa in Mi-mag[g]iore (E-dur), op. 9 (mešani zbor, orgle; nedokončano)

Figura $v$ miniaturah za violončelo in klavir Iz Miniatur za klavir (violina, klavir; gl. Miniature za klavir) Miniature za flavto in gambo

Miniature za klavir

Miniature za solo violino

Pet miniatur za flavto in klarinet

Šest miniatur (pihalni trio)

Himna brigade (dvoglasni zbor) Na Balkanu (dvoglasno) 


\section{MUZIKOLOŠKI ZBORNIK • MUSICOLOGICAL ANNUAL XXXV}

Na sve načine (enoglasno)

Zidari (enoglasno)

- motet:

Beati immaculati (ženski zbor, orgle)

Beati immaculati za deški zbor

Deus Israël conjungat vos (bariton, orgle)

2 moteti in honorem S. Caeciliae (ženski zbor)

Loquebar za ženski zbor

- nabožna glasba:

- nokturno:

- odrska glasba:

- opera:

- pastorala:

- ples:

Cantabo Domino (glas, orgle)

Ot'če naš' (moški zbor)

Sv. Benedikt [I] (mešani zbor)

Sv. Benedikt [II] (mešani zbor)

Tebe ljubi moja duša (ženski zbor, orgle)

Venturini: Jagnje božje (mešani zbor)

Dva nokturna za kitaro

Mali nokturno za klavir

Nokturno (gl. Bagatele za klavir)

Nokturno (komorni orkester)

Nokturno (kvartet flavt)

Nokturno za violo in klavir

Trije nokturni za flavto in vibrafon

Trije nokturni za kontrabas

Kristalni gozd (komorni ansambel)

Mrak: Chrysippos (kljunasta flavta)

Plautus: Dvojčka (komorni orkester)

Shakespeare: Sen kresne noči (recitator, klavir)

Čudodelna roka, op. 2

Kako je pridna Micka prišla v nebesa, op. 1

Orpheus in Euridika, op. 4

Paževa usoda, op. 3 instrumentarij)

Pastoral za blokflavto in klavir

Pastorale (gl. Mala suita za klavir)

Pastorale (klavir)

Trije pastoralčki (flavta, čembalo)

Trije pastoralčki za altovsko flavto in harfo

3 pastorali za oboo d'amore in klavir
Veni Sancte Spiritus (ženski zbor, dve violi, violončelo)

Pastoral (dve flavti, trikotnik, činele; gl. Mladinske skladbe za Orffov

Pastoral (violina, klavir; gl. Miniature za klavir)

Afriški ples (flavta, ksilofon, paličice, boben; gl. Mladinske skladbe za Orffov instrumentarij)

Corale + Siciliana (gl. Suita za 2 violini, violončelo in godalni orkester) Gavotta (klavir štiriročno; gl. Suita za 2 violini, violončelo in godalni orkester)

Gavotte (gl. Suita za 2 violini, violončelo in godalni orkester)

Gigue (gl. Suita za 2 violini, violončelo in godalni orkester)

Koral - Siciliana (klavir štiriročno; gl. Suita za 2 violini, violončelo in godalni orkester)

Mali ples (gl. Tri skladbice za Polonco za klavir)

Menuet (gl. Suita za 2 violini, violončelo in godalni orkester)

Menuet (klavir štiriročno; gl. Suita za 2 violini, violončelo in godalni

orkester)

Ples (mladinski zbor; gl. Kanoni za 2 ali 3 glasove) 


\section{MUZIKOLOŠKI ZBORNIK • MUSICOLOGICAL ANNUAL XXXV}

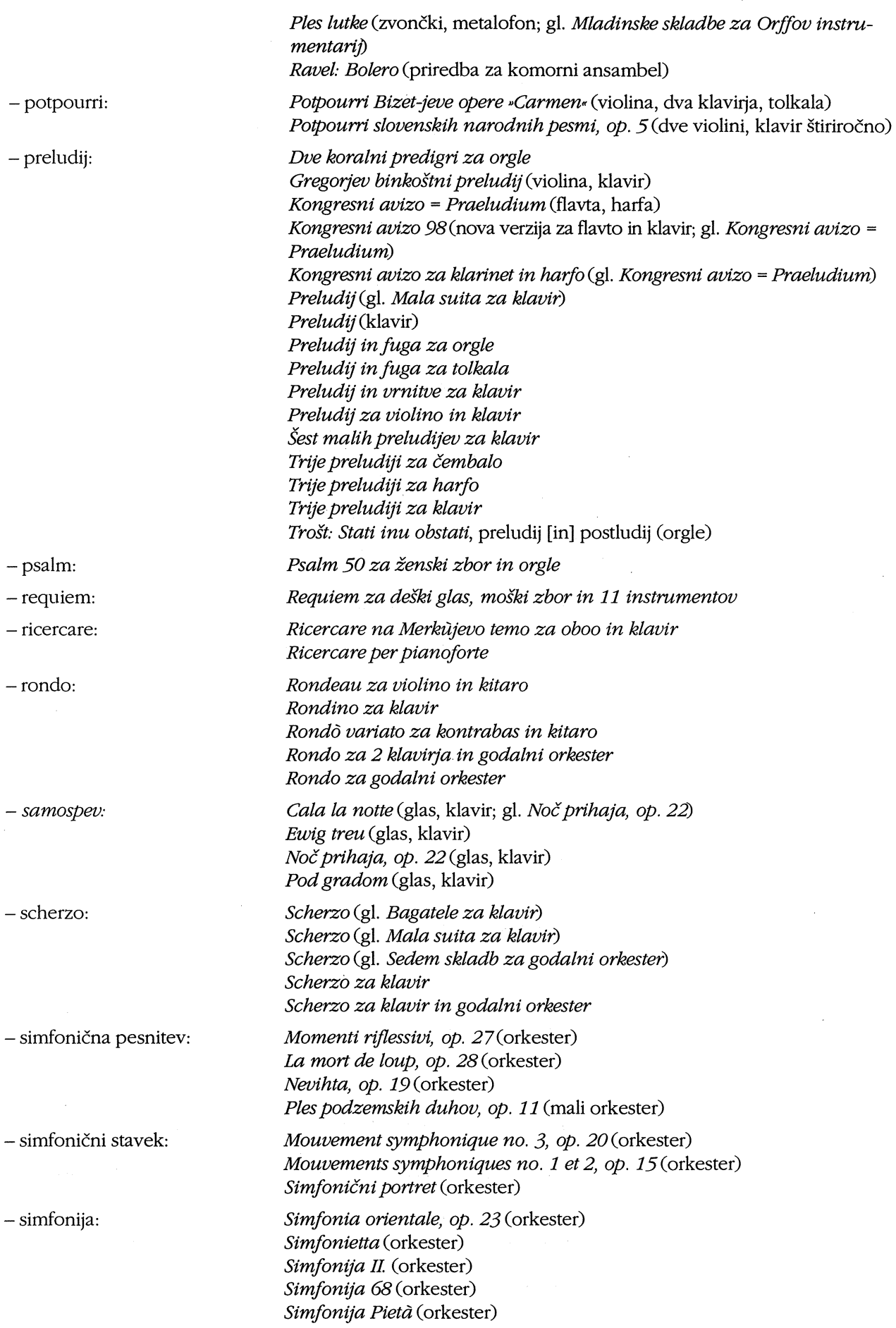

Ples lutke (zvončki, metalofon; gl. Mladinske skladbe za Orffov instrumentarij)

Ravel: Bolero (priredba za komorni ansambel)

- potpourri:

Potpourri Bizet-jeve opere "Carmen" (violina, dva klavirja, tolkala)

Potpourri slovenskih narodnih pesmi, op. 5 (dve violini, klavir štiriročno)

- preludij:

- psalm:

- requiem:

Dve koralni predigri za orgle

Gregorjev binkoštni preludij (violina, klavir)

Kongresni avizo $=$ Praeludium (flavta, harfa)

Kongresni avizo 98(nova verzija za flavto in klavir; gl. Kongresni avizo = Praeludium)

Kongresni avizo za klarinet in harfo (gl. Kongresni avizo = Praeludium)

Preludij (gl. Mala suita za klavir)

Preludij(klavir)

Preludij in fuga za orgle

Preludij in fuga za tolkala

Preludij in vrnitve za klavir

Preludij za violino in klavir

Šest malih preludijev za klavir

Trije preludiji za čembalo

Trije preludiji za harfo

Trije preludiji za klavir

Trošt: Stati inu obstati, preludij [in] postludij (orgle)

- ricercare:

- rondo:

- samospev:

Psalm 50 za ženski zbor in orgle

Requiem za deški glas, moški zbor in 11 instrumentov

Ricercare na Merkùjevo temo za oboo in klavir

Ricercare per pianoforte

Rondeau za violino in kitaro

Rondino za klavir

Rondò variato za kontrabas in kitaro

Rondo za 2 klavirja.in godalni orkester

Rondo za godalni orkester

Cala la notte (glas, klavir; gl. Noč prihaja, op. 22)

Ewig treu (glas, klavir)

Noč prihaja, op. 22 (glas, klavir)

Pod gradom (glas, klavir)

- scherzo:

Scherzo (gl. Bagatele za klavir)

Scherzo (gl. Mala suita za klavir)

Scherzo (gl. Sedem skladb za godalni orkester)

Scherzo za klavir

Scherzo za klavir in godalni orkester

- simfonična pesnitev:

Momenti riflessivi, op. 27(orkester)

La mort de loup, op. 28 (orkester)

Nevihta, op. 19 (orkester)

Ples podzemskih duhov, op. 11 (mali orkester)

- simfonični stavek:

Mouvement symphonique no. 3, op. 20 (orkester)

Mouvements symphoniques no. 1 et 2, op. 15 (orkester)

Simfonični portret (orkester)

- simfonija:

Simfonia orientale, op. 23 (orkester)

Simfonietta (orkester)

Simfonija II. (orkester)

Simfonija 68 (orkester)

Simfonija Pietà (orkester) 


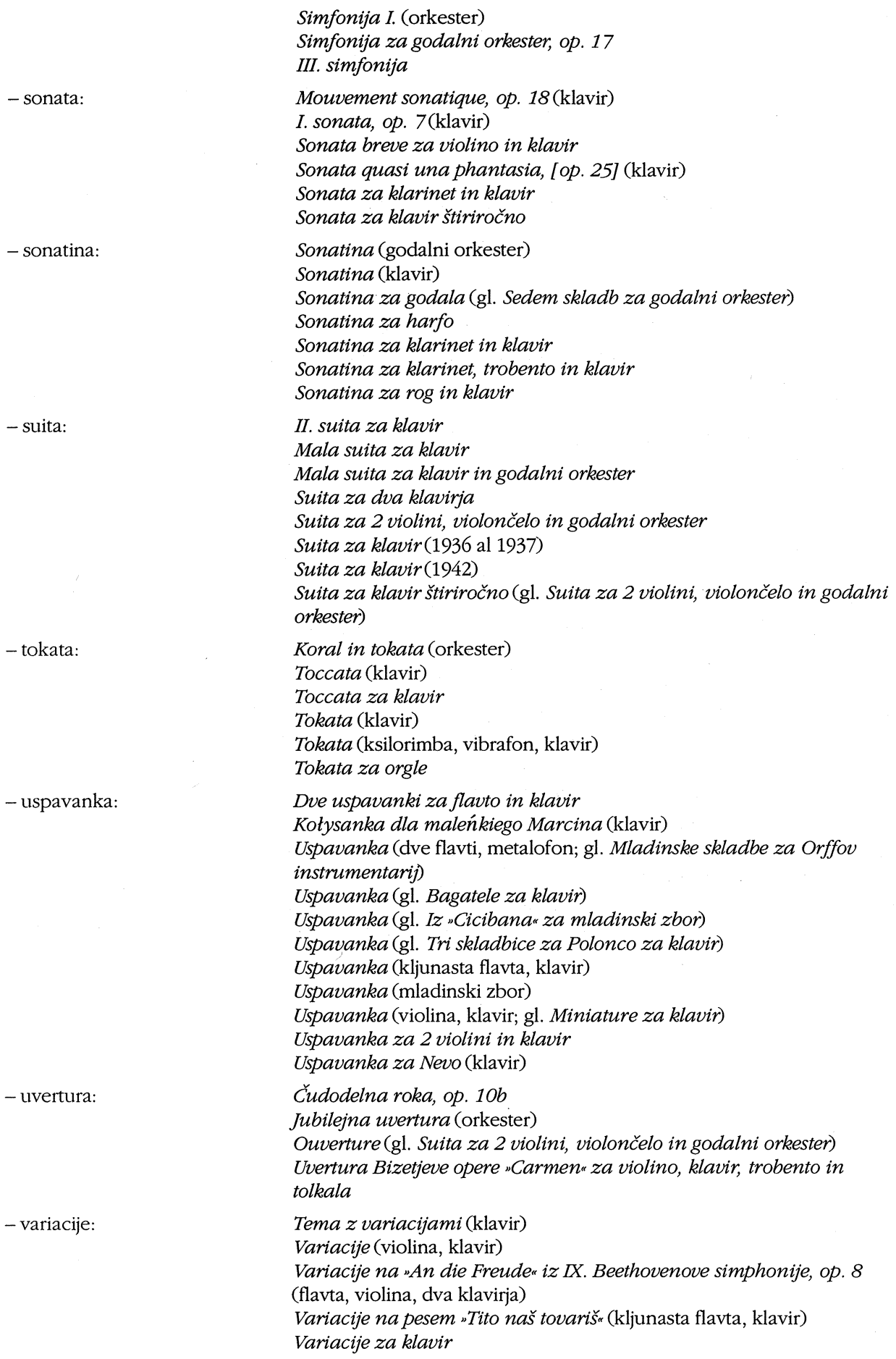




\section{MUZIKOLOŠKI ZBORNIK • MUSICOLOGICAL ANNUAL XXXV}

- žalna glasba:

Marcia funebre, op. 6(klavir)

Musica funebre (orkester)

Musiques funèbres (orkester)

Žalna koračnica (duo flavt, pavke, boben; gl. Mladinske skladbe za

Orffov instrumentarij)

\section{The Catalogue of Works by Composer Primož Ramov̌̌}

\section{Summary}

The catalogue of works by Primož Ramovš, a member of the Slovene Academy of Science and Art, contains the data about his compositions and their publication in print. The catalogue is based on the preserved manuscripts and/or fair copies of his works, composer's list of works, previously published lists of his works, and catalogues from major libraries. The majority of the composer's manuscripts and fair copies of his works are kept in the Music Collection of the National and University Library; it is specifically noted if they are in other locations.

The catalogue of the compositions is organized in alphabetical order according to the first letter of the composition's title. The data follows this pattern: the title, the instrumentation, the place and date of composition, a description of the physical shape of the material (manuscript and fair copy); at the end there is a note about the title and a citing of the dedication. The data about the printing(s) follow the description of the manuscript (fair copy). The title which begins with a numeral is resolved, and the one in other alphabet, transliterated. In cases of publication a title is omitted if it is identical to the one in the manuscript; when it comes to multilingual covers, the parallel titles are also omitted. Then follows a noting of the place of publication, the publisher, the year of publication, data about the physical shape of the publication, the title of the collection and the publishing number. The bibliography consists of published material which was issued by the end of October, 1999.

Added to the catalogue are a chronological list of works, an index according to instrumentation, and an index according to forms and genres. The chronological list is arranged by dates which almost without exception were given by the composer at the end of the composition. Manuscripts without a mention of the year are classified chronologically on the basis of other sources. The index of forms and genres is arranged in alphabetical order. 